Author: Michener, Ezra

Title: A manual of weeds, or, The weed exterminator

Place of Publication: Philadelphia

Copyright Date: 1872

Master Negative Storage Number: MNS\# PSt SNPaAg033.4 
$<1225543>{ }^{*}$ OCLC ${ }^{*}$ Form:mono 2 Input:GRB Edit:FMD

008 ENT: 980219 TYP: $s$ DT1: 1872 DT2: LAN: eng

035 (OCoLC) 38246571

037 PSt SNPaAg033.4 \$bPreservation Office, The Pennsylvania State University, Pattee Library, University Park, PA 16802-1805

09010632.58 \$bM58m \$cax ${ }^{*} 31778541$

09020 Microfilm D344 reel 33.4 \$cmc+(service copy, print master, archival master)

1001 Michener, Ezra \$d1794-1887.

24512 A manual of weeds, or, The weed exterminator \$bbeing a description, botanical and familiar, of a century of weeds injurious to the farmer : with practical suggestions for their extermination \$cby $E$. Michener.

24630 Weed exterminator

260 [S.I. \$bs.n.] \$c1872 \$ePhiladelphia \$fKing \& Baird, Printers

300 xx, 148 p. $\$ c 19 \mathrm{~cm}$.

500 Includes index.

533 Microfilm \$bUniversity Park, Pa. : \$cPennsylvania State University \$d1997. \$e1 microfilm reel ; $35 \mathrm{~mm}$. \$f(USAIN state and local literature preservation project. Pennsylvania) $\$ f(P e n n s y l v a n i a$ agricultural literature on microfilm).

590 Archival master stored at National Agricultural Library, Beltsville, MD : print master stored at remote facility.

590 This item is temporarily out of the library during the filming process. If you wish to be notified when it returns, please fill out a Personal Reserve slip. The slips are available in the Rare Books Room, in the Microforms Room, and at the Circulation desk.

6500 Weed control.

8300 USAIN state and local literature preservation project. \$pPennsylvania.

8300 Pennsylvania agricultural literature on microfilm. 


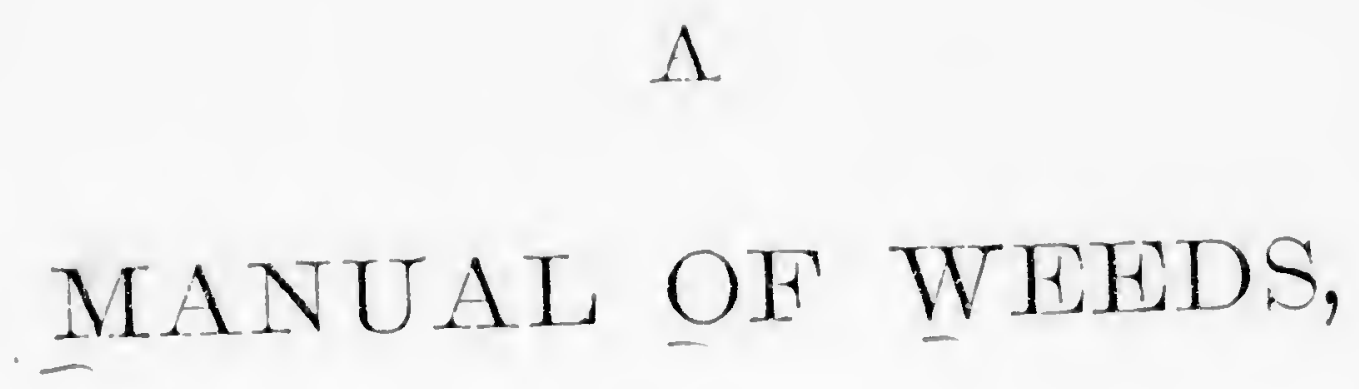

OR THE

\section{WEED EXTERMINATOR;}

BEIS゚

A DESCRIPTION, BOTANICAL AND FAMILIAR, OF A CENTURY OF WEEDS INJURIOUS TO THE FARMER,

WITII

PRACTICAL SUGGESTIONS FOR THEIR EXTERMINATION.

BY E. MTCUENER, M. D.

"I went by the field of the slothful; and by the vineyard of tho man yoid of understanding; and lo, it was all grown over with thorus; nettles had covered the fice thereof; and the stone wall was broken down.

"I looked upon it, and recoived instruction."-Snlomon.

\section{P IIILA DELP II I A :}

KING \& BAIRD, PRINTERS, 607 SANSOM STREET. 1872 . 
TO TIE

FARMERS' CLUBS,

To THI

YOUNG, THE INTELLIGENT, THE ENTERPRISING CULTIVATORS OF TUE SOIL,

WHEREVER FOUND,

区ुhis : As a Tribute of Respect,

BY THE AUTHOR.

"The perfection of beanty, in a farm, consists in fertile fields, producin

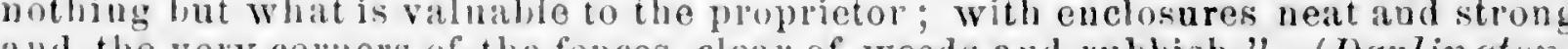

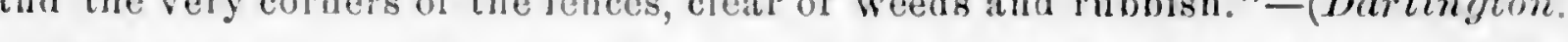

"While the physical sciences, in every other denartment, are advancing with gigantic strides, the prond profession of Agriculture, shond disdant to be fonthe of an intellectual pursuit."-(Uhid.)

$$
36704
$$


ERRATA.

Want of experience in proof reading; the unfimiliar technicali. ties of descriptive Botany ; and my distance from the Printing oflice; have allowed a few typographical errors, to pass unno. ticed. Such as have been observed, and are likely to mislead the reader, are mentioned below, and had better be corrected by him.

Page 2, line 7, plice a semicolon (;) after the word inside.

“ 3 , “ 4 , for pellate, read peltate.

8 , from the bottom for not, read nut.

“ 5, " 9, “ " " " for supal, read sepal.

" 7, " 13 , for punctuate, reat punctate.

" 11, " 6, from the bottom, place a semicolon (;) after belone.

" 12, " 11 , " " "
9 , " " " "

" 21, , 6 , " " " remove the comma (,) afte!

“ 25, 6 5, for wooly, read woolly.

8 , for 5 , read 3

16, for object, read objects.

“ 26, “ 7 , from bottom, for pedicels, read petioles.

“ 28 , “ 11 , for alternate, read ultinate.

" 23, " last line, per-annual need not be italicised.

" 40, " 16, insert annual, before stem.

“ 41, " 7, from bottom, place a comma (,) after branched.

"44, " 14 and 16 , for cilliate, read ciliate.

“47, “ 7, from bottom, por-annual need not be italicisod. 


\section{$A D D E N D A$}

Page 42, line 6. "Less common." The observations of the list summer require me to recall this; and to say, that within the last year there has been a fearful increase of this, and other noxious weeds, in this portion, at least, of Chester county ; both in the fields, and along the public highways, and railroads. In relation to them, slothful indolence, and heartless indifference; almost everywhere, reigns supreme. The highly reprehensible practice of throwing refure weeds (Docks, Burs, \&c., \&c.,) into public roads, water courses, \&c., \&e., where they necessarily inflict serious injury, apon themselves, and others; can not be too severely censured. Tirough the offenders may fail to adopt this vieno of the case; the damage which they thus do, to a neighbor, may be greater, than whit the incendiary torch would occasion. The vorongs, and crimes, of omission; may be cqually as great as those of commission.

\section{SYNOPSIS OF THE MANUAL, \&C.}

It is not the wish of the writer, that this small, and unpretentious volume, should supersede the larger and more complete, Agricultural Botany, of his excellent friend, the late Dr. William Darlington. It, and the more elaborate Frora Crstrica, will continue to be, an honorable memento of his Botanical acumen, and scientific attainments.

To me is allotted the humbler task; to place in the hands of the young, and intelligent, culturist, whether on the farm, or in the garden, a cheap, and reliable HandBOOK OF WeEDS.

To paint, in strong colors, a finger-board, which shall contimually, direct his attention to the noxious plants which everywhere encumber his path.

To suggest means, based upon a practical study of the natural listory, and habits, of the weeds themselves, for their successful extermination.

In the fulfilment of this important purpose, no apology will be required, for following closely, and copying largely, from the works referred to.

Nor can I too strongly recommend, to every one who desires to obtain a practical knowledge of the subject, to study, carefully, the elementary works of Prof. Asa Gray; especially his "How Plants Grow," and his "Botanicat TExT-BOok." 


\section{WHAT IS A WEED?}

$\Lambda$ griculture is a perpetual conflict with aggressive plants. A conflict which must ever constitute a material part of the labor necessary to be expended on a well-conducter farm. It is therefore, necessary, with a view to the cconomy, as well as the final success, of the operation; that such labor should be wisely directed. Here, as elsewhere, knowledge is power. A knowledge of the general nature, and the peculiar lrabits, of the plant to be operated on, is indispensable, to direct the operator how, properly, to adapt the means at his disposal, to the intended purpose.

The term weed. as here used, is not applied to any particular plant, or assemblage of plants. All plants become weeds, in an agricultural sense, when found growing where they deteriorate other crops, needlessly exhaust the soil, or otherwise, bring loss to the agriculturist.

\section{"Every plant, out of place is a Weed."}

Weeds may be either:

Herbaceous, Fruticose, or Arboresent.
Annual,
Rhizomatous, Bubiferous, or Tuberiferous,

Weeds produce seeds and seeds produce weeds. The former are called seed-ing, the latter seed-ling, weeds.

The conditions, and habiturles of the numerous species of weeds, are so diversified as to require a separate study of cach, in order to determine how it can be most successfully attacked. The means for their removal must not only be different, but sometimes directly opposite. Thus, the judicious use of the plow, and harrow, may effectualiy destroy a large majority of weeds: but there are others- the Rhizomatous, Bulbiferous, and Tuberiferous, forms, which would be broken to pieces, separated, and widely dispersed, by such means, while each fragment left in the soil, would vegetate, and form a new plant, greatly aggravating the evil, as we shall have occasion more fully to consider.

The intelligent operator will first inquire, what is this weed? Is it an annual? a bi-annual? a per-annual? at what season does it ripen seed? has it any other mode of reproducing its kind? and whal? what crops does it affect? are its fragmentary roots vivacious, and capable of prodncing new plants, when suffered to remain in the soil? when these, and similar inquities have been duly answered, le will have learned two important lessons,

What to do, and How to do it.

To facilitate the acquisition of this knowledge, I have tabulated the species of plants embraced in this work, according to their respective duration, and other leading characteristics, which have a special relation to the means best adapted to their extermination. The plants composing each list, being analogous in these respects, may be considered as requiring the same general management: subject to such minor modifications as the habits of each species may suggest.

\section{List No. I. ANNUALS.}

The plants of this list, spling up, blossom, perfect their fruit, and perish, by the close of the first season. If prevented from ripening seeds, their destruction will be complete. This important, but plain and simple indication, can generally be fulfilled, either by tillage, by hand- 
pulling, by the hoe, or by the scythe. Perseverance is always an essential element in the destruction of weeds. Tho this list belong:

3. Papaver dubium.

4. Argemone Mexicana.

5. Camelina sativa.

6. Capsella bursa pastoris.

9. Lychnis githago.

10. Portulacca oleracea.

11. Abutilon avicennse.

12. Sida spinosa.

21. Sicyos angulata.

38. Ambrosia trifida.

39 .

0. artemissiafolia.

strumarium.

41. spinosum.

42. Bidens frondosum.
43. Bidens bi-pinnatum

44. Maruta cotula.

58. Sonchus oleraceus.

69. Lithospermum arvense.

74. Datura stramonium.

75. Solanum nigrum.

83. Chenopodium album.

84. Amaranthus hybridus. 85. spinosus.

6. Polygonum arifoliun

89. Eupho:bia hypericifolia. 100. Cenchrus tribuloides.
4\%. Erechtites hieracifolia.

\section{List No. II. BI-ANNUALS.}

Plants of this division, spring from the seed, forming what is termed seedling-plants; but do not, usually, blossom, and produce fruit, until the second year' after which they soon perish, as the annual ones do. The indication is therefore much the same as for them. The labor may be bestowed upon the seedling plants of the first year, or on the seeding ones of the second. But where the time for operating is optional, it is much the safer, and better plan to root out the young and tender seedlings, than to await their more vigorous development. The work is much easier accomplished, the soil is left free from encumbrance for other erops, and if any of them should escape destruction, there is less danger from their production of seed.
It must be borne in mind, that the line between amnuals, and bi-annuals, is so loosely defined, that some on either side may, occasionally trespass upon the other, by assuming its prerogative.

20. Oenothera biemnis.

22. Daucus carota.

23. Heracleum lanatum.

24. Archemora rigida.

25. Archangelica atrop 27. Aethusa cynapium.

2S. Cicuta maculata.

29. Conium maculatum.

31. Dipsacus sylvestris.

32. fullorum.

49. Cirsium lanceolatum.

$49 . \quad$ discolor.
50. Cirsum altissimum.

51. muticum.

52. pumilum.

53. horridulum

55. Onopordon acanthium.

59. Plantago major.

60. Verbascum thapsus.

61. blattaria

68. Echium vulgare.

97. Bromus secalinus.

99. Lolium temulentum.

\section{List No. III. PER-ANNUALS.}

Plants of indefinite duration. When once matured, they continue to produce flowers, and fruit, for a series of years. In the herbaceous kinds, the leaves and stems mostly perish, annually, the root only, being per-annual, (Rumex, or Dock). In the fruticose, and arborescent forms, the leaves generally fall with the scason, the more hard and wooly stems being sometimes bi-annual, (Rubus. or Blackberry) and sometimes per-annual (Rhus, or Sumach).

It will be perceived that this list contains a very variable, and interesting group of weeds, which must, necessarily, require different modes of treatment for their removal. For many of them, good tillage, and high farming will be 
found sufficient to control, or eradicate them. Others will require hand digging, \&c.

In this list may be placed :

2. Menespermun canadenss. 46. Leneanthemum vulgare.

7. Hypericum perforatum. 56. Lappa major.

$\begin{array}{ll}\text { 13. Malva rotundifolia. } & \text { 5\%. Taraxacum dens leonis. } \\ \text { 14. Rlabra. } & \text { 63. Verbena hastata. }\end{array}$

15. venenata.

16. toxicodendron.

17. Rubus villosus.

18. canadensis.

19. Rosa carolina.

33. Vernonia novæboracensis.

34. Eupatorium perfoliatum.

35.

36. Aster cricoides

37. Solidago nemoralis. purpureum.

63. Verbena hastata. 64. urticiefolia. 65. Leomurus cardiaca. $66 . \quad$ marrubiastrum. 70. Cynoglossum morissonii. 76. Solanum duleamara.

81. Asclepias incaruata.

82. Phytolacea decandra.

87. Rumex crispus.

88. obtusifolins.

90. Symplocarpus fotidus.

\section{List No. IV. BI-PER-ANNUALS.}

The plants arranged in this list, really are both biammual and per-annual. By virtue of a super-added function, they combine the characters of the two divisions. They grow, produce fruit, and then die, as other bi-annuals do, but while that process is going on, they are also preparing to propagate their kind, by means of root-stocks, or under-ground stems, called Rhizomas. These rhizomes assume three different forms.

1. Rhizones proper. They are root-like stems, extending horizontally beneath the surfice, provided with buds, and often, with scales, representing undeveloped leaves, and producing rootlets for their own sustenance. When

sufliciently matured, they send up stems to the surfice, form a crown of leaves, and thus become, what we may call Rhizomalous plants, possessing all the essentials, root slem and leaves, of an independent existence; similar to seedling plants. The death of the parent root does not affect them.

2. Burbs. Which are only modifications of the rhizome, containing a germ of the new plant; and capable of complete derelopment; but does not usmally vegetate, until the next year. The major part of the bulb is composed of nutritious matter, stored away, by the provident parent, for the sustenance of the nascent germ, before its own rootlets can be made to nourish it. The kernel, or albuminous portion of seeds, is, in the same way, provided for the support of the included embryo. Bullos are generally produced by bulb-rooted plants (Ornithogalum, or ten o'clock). Sometimes in the axils of the leaves (Lilium bulbiferum, or bulb-bearing lily). And sometimes the fructification is converted into bullss (Allium, or garlic). Ilowever produced, when they vegetate, they assume the conditions of seedlings and may be called bulbiferous plants.

3. TuBbrs. These are only another form of the rhizome, where instead of immediately developing new plants ; the nutritious matter is deposited in the extremity of the root-stock, there to be preserved, to nourish the embryo, during its nascent growth, in the succeeding spring (Solanum, or potato). Although arranged, and developed, in a diflerent manner, the functional conditions of bulbs and tubers, are very similar.

Hence the bi-per-ammal plants naturally present three divisions of the list. 
xiv

SYNOPSIS OF MANUAL, ETC

\section{A. RHIZOMATOUS.}

8. Saponaria offeinalis.

20. Aegopidum podagraria.

30. Sambucus canadensis.

45. Achillea millefolium.

¿4. Cirsium arvense.

62. Linaria vulgaris.

67. Teucrium canadense.

71. Calystegia sepium.

22. Calystegia pubescens.

7:3. Convolvulus arvensis.

7\%. Solanum carolinense.

78. A pocynum androsamifolium

79. cammabium.

80. Asclepias phytolaccoides.

96. Cynodon dactylon.

93. Triticum repens.

\section{B. BULBIFEROUS.}

1. Ramunculus bulbosus.

92. Allium vineale.

91. Ornithogalum umbellatum. 93. Cyperus strigosus?

\section{TUBERIFEROUS.}

94. Cyperus repens.

95. Cyperus hydra.

The sagracious reader will pereeive that the most pestiferous. weeds, those most diflicult to exterminate, and consequently, the most to be dreaded, obtain in this list. On further inquiry it wi:l also appear, that their reproduction by means of thizomes, is vastly more annoying to furmers, by seeds.

The great importance of this subject may warrant some general observations, at the risk of their recurrence, in the letails of the manual.

Rhizomes of every form, are very tenacious of life, and will generally bear a great deal of exposure, before they will perish.

Bulbs, and tubers, are almost as retentive of their vital ity as seeds, and nuts.

lihizomes proper, being well provided with buds, and mostly very friable; are readily broken into fragments, when each pice which retains a bud, soon vegetates, and forms a new plant (Cirsium, or Canada thistle).

Bulbs, annually, form a corona of small bulblets, around the parent (Allium, or garlic). 'These bulblets are easily separated, and dispersed, where they speedily form new plants.

T'ubers are sometimes produced even in much greater abundance (Cyperus, or Coco grass). From a kindred species of Cyperus, I collected 500 tubers, which were about the half of the ammal product of one such tuber, planted in the spring.

A few general propositions of a practical character may not be out of place, in relation to weeds in general; but more especially, to those of the present division (Biper-anmuals).

1. Never permit a noxious weed to mature, and sow, its seels.

2. Whenever the leprosy spot appears, no matter whether it is measured by inches, or by acres; immediately circumscribe it, in such a way, that no process of tillage, no agricultural implements; or other means can carry its roots into healthy gromel.

3. Whenever practicable, thorough hand-digging, and the destruction of the roots; shou!d precede all other operations. Carefully watching for, and promptly remoring, any remaining plants, as soon as they appear.

4. Vegetable physiology teaches, that the leaves of plants, are the essential organs of digestion, assimilation, and respiration. They are the ritalizing, life-sustaining organs of the plant. Hence it follows, as an obvious corollary, that the leares, as they are the most accessible; so they are also, the most vulnerable part of the organism; 
and presents a favorable point for the firmer to commence the work of extermination.

5. Prevent the formation of leaves, and the vital functions will soon cease to be performed. Arrest the vital functions, and the root will perish. This is the grand ARCANUM for the destruction of pestiferous, and highly
vitalized weeds.

The following extract is worthy to be remembered by every farmer.

"By whatever means the foliage, or leares and stalks of the plant, are continually, and frequently, destroyed, for one season, or two at most, during the months of June, July and Septem?er, will destroy the Canada thistle.

"It is a settled principle in physiology; that leaves are that without vegetables, as lungs are to animals; and the without the healthful exercise of these organs, both ullimately die. Leares animal will become diseased, and plants, as rootsare are as necessary to the roots of pendent on each othe the leares. They are mutually dethe other. The repenter, and cannot long exist without plant, therefore, repeated, and complete, defoliation of a effectual mode of and an

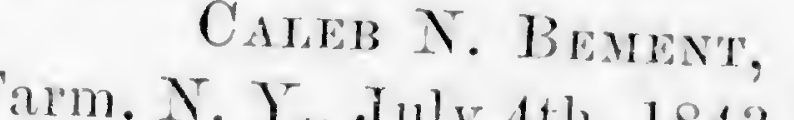
(Farmer's Cabinet, vol. 8, p. 87.)

6. There are various means which may be resorted to for preventing the formation, or reproduction, of leaves. These should be selected, according to their adaptability o the circmstances of each particular case. They are: a. Garden culture. Hand-weeding, and the hoe. b. Farm tillage. With plow, harrow, \&c. Frequent stirring, and thorough pulverization of the soil.

c. Suffocation. By poisonous applications. By heary mulching, with straw, bagasse, spent tan, \&c., dc.

By high farming. Which means, heavy manuring, good tillage, and the production of an abundant growth of the grain and grass crops; so as thereby to smother out, and suffocate, all worthless and pernicious, products.

7. Other subordinate means should be resorted to, as circumstances may indicate, some of which will be noted in the progress of the work.

8. When, by watchful attention, and persevering industry, the offensive weeds have all been extirpated, a truce has been obtained, but the victory may not have been fully achieved. The soil may have been filled with the sceds of preceding years, which will very likely, vegetate, and canse renewed trouble, as the processes of tillage bring them successively to the surface, where they can feel the vitalizing influence of light and air. Hence, the necessity for continued watchfulness, and prompt action, so long as the danger exists. 


\section{FARINERS, ATTENTION}

Permit me, for a moment, to call your attention, to the IEGAI ASPECT of this weedy question.

Much anxiety, and alarm, exists at the present moment and not without abundant cause, among the more intelli gent portion of the agricultural community, on account of the rapid increase, and spread, of noxions weeds, while, unhappily, the mass of the people, appear to be stolidly ignorant, and indiflerent, alike, to the stolidly tent of the dangel.

It is not a question merely, of individual, of local, or of agricultural interest. It is more than all these. It is national. National in all its bearings. A national disease. A national nuisance. A depreciation of the value of the national property, and consequently, must lessen the national resonices.

$\Lambda$ dreadful leprosy is rapidly spreading its deadening pall, over the agricultural interests of the country. Whole districts of our best lands, north, and south, have already. been rendered comparatively valueless, and unproductive, by the negligence, and supineness of their owners, in suffering them to become infested, and overrun, with pernicious weeds. Nor is this the extent of the mischief. 'Those foul lands, necessarily become the pestiferous centres, from which the loathsome malady is continually infecting the healthy districts around them, despite all the efforts of the owners to ward ofl the discase.

As the land is properly the basal representative of national greatness; so the products of the soil must represent the national yesources. It must, therefore, be the duty, as it obviously is, the interest, of the nation, to maintain, with sedulous care, the health, and the integrity, of its agriculture, and protect it against every contamination.

'The tarly arm of the law, has been invoked for this purpose, but with small benefit. Law, to be effectual, must not, merely, confer the power to act, upon its agents ; it must also, provide for them, the means for executing it. It is not likely, therefore, that any law will afford much relief, in the premises, until the State, and national powers, and resources, can be brought into requisition.

Our cities assert the right, and resolutely exercise it, to protect themselves against the invasion, and spread, of diseases, by means of quarantine laws, the abatement of nuisances, the rigrid enforcement of hygienic regulations, and eren the forcible cxclusion of the occupants from their own premises, if occasion should require.

'The farmers of' a district possess the same rights, why should they not be allowed to exereise them? It is time for them to assert their claims to justice. It is time for then to demand the establishment of an AGRICUnTurat BOARD of IBALTH in every district, invested with ample powers, and resources, to maintain a healhy agriculture. The subject may be diffeult, but the difliculty is not equal to the dangers which threaten us. Let us act deliberately, cautionsly, wisely, but with a determination that will insure redress.

The sate of impure seet, and grain, for sowing, is productive of much dificulty, and loss to the purchaser. It may be necessary to provide inspection of seeds, before they are allowed to be sold.

A farm, stocked with Canada thistle or other noxions weeds, in an agricultural district, is a horrible nuisance, both public, and private. It may be necessary to concen- 

trate the resources of the district for its thorough cleans-
ing.

The sluggard occupant, I will not call him "firmer," is often a worse nuisance, to neat farmers, than his foul, is neglected, fields. It may be necessary, to remove him tomporarily from his premises, and to place them in the cleansed fiom thent, till they are fully ventilated, and arise, whether the and the question may even out of the premises, or hiall receive his compensation

You may call these but do not call them "uggestions bold, what you please, are founded upon "utopian." They are not so. They basis of equal, and reciprocal, miversally acknowledged sustain, all riohtly controcal, rights, which underlie, and ganizations.

\section{HAND BOOK OF WEEDS;}

or

\section{WEED EXTERMINATOR.}

SERIES I. Phænogamous; or Flowering Flants.

Vegetables bearing proper flowers, with stamens and pistils, and producing seeds, which contain an embryo, or rudimentary plantlet.

CIASS I Exogenous; or Dicotyledonous Plants.

Stems formed of distinct bark, wood, and pith; leares inostly netted-reined; embryo with 2 (rarely more), opposite cotyledons.

SUB-CLASS I. Angiospermous; Exogenous Plants.

Pistil a closed ovary, containing ovules, and becoming the fruit; pollen applied to a stigma; cotyledons 2.

DIVISION 1. Dyalypetalous; Exogenous Plants.

Floral envelopes consisting, generally, of both calyx, and corolia, with the petals mostly distinct.

\section{Order I. RANUNCULACERE}

Herbs, or wooly vines, with a colorless, and often acrid, juice; leaves usually dissected; stipules none; petals sometimes wanting; and the calyx corolla-like, hypogynous; the sepals, petals, numerous stamens, and many, or few, (rarely single) pistils, all distinct, and unconnected; seeds with firm, fleshy albumen; embryo minute. 


\section{Tribe 1. RANUNCULEA.}

Sepals imbricated in the bud; petals conspicuous, flat; carpels numerons, 1 seeded; stem-leaves alternate. Mostly per annual herbs.

\section{Genus I. RANUNCULUS.-Linn.}

Sepals 5 ; petals usually 5 , mostly longer than the sepals, each with a little scale, or pit, at base, inside carpels in a head, compressed, pointed.

* Leaves termately divided; petals longer than the sepals.

\section{R. BULbosus.-Limn. Butter-cups. Crow-foot.}

Hairy ; stem erect, from a solid bulb; radical leaves 3 parted, the terminal division petiolulate; perluncles sulcate; calyx reflexed.

Per-annual. Stem 9 to 15 inches high, often cespitose, more or less branched; rarlical leaves ternate, and quinately pinnate, on petioles 2 or 3 to 6 inches long; stem leaves deeply, and pinnatifilly, incised; peduncles terminal, or opposite the leaves, 1 to 4 inches long, furrowed and angular; earpels with a short reçurved beak.

Hab. In meadows. Exotic. Fl. May. Fr. July.

Obs. This, together with several co-ordinate species, have been introduced, and are gradually coming to be pernicious, and intractable, intruders. R. bulbosus is mostly observed in low grounds, along streams; and often in cul tivated lots. There is a strong family resemblance of the species_so that a knowledge of one sort may lead to an aequaintance with all. The bulbous root, no doubt, makes this species more tenacions of life. Two crops of oats in immediate succession-or keeping the soil constantly stirred, so as not to allow any leaves_or lungs_to be formed-are perhaps the most efficient means for its extermination.

\section{Order II. MENESPERMACEA.}

Suffruticose climbers; leaves pellate, or palmate, alternate, without stipules; sepals, and petals, similar, in 3 , or more series, imbricated in the bud, hypogynous; polygamo-dioicous ; pistils 3 to 6 ; fruit a drupe, seed 1 , with a large, curved, embryo, and little albumen.

\section{Genus II. MENESPERMUM.-Liin}

Flowers dioicous; sepals and petals, arranged in fours, in 2 or 3 series; stamens 12 to 20 ; anthers 4 celled; pistils 2 to 4 , somewhat stipitate; drupes roundish reniform.

\section{M. CARADENSE.-Linn. Moon-seed.}

Leaves peltate near the base, 3 to 7 angled, or sub-lobed; flower's in axillary, paniculate, racemes.

Per-annual. Stem 3 to 15 feet long, slender, nearly simple, twining, or climbing over bushes, \&c.; leaves 3 to 5 inches long, rather wider than long, sub-cordate at base; petioles 3 to 4 inches in length; flowers small, of a dingy, yellowish-green, tinged with purple; petais 8 , smaller than the sepals; drupes black, with a bloom, when mature; not wrinkled, lunate.

Hab. In thickets, fence-rows, sc., rare. June. Sept.

Obs. The tempting, grape-like, fruit of this plant, renders it dangerous to children, who have sometimes lost their lives by eating of it. This will not seem strange when it is known that it is congeneric with the fimous Cocculus Indicus, so much used for poisoning fish, and whiskey drinkers. It should be carefully exterminated. 


\section{Order III. PAPAVERACEA}

Herbs with a milky, or colored juice; flowers regular, polyandrous, hypogynous; sepals caducous ; fruit mostly a 1 celled pod, or capsule, with 2, or more parietal placentre, which sometimes form imperfect partitions; seeds numerous, often crested; embryo small, at the base of fleshy, and oily, albumen.

* Juice white; seeds not crested.

\section{Genus III. PAPAVER-Linn}

Sepals mostly 2 ; petals 4 ; stigmas 4 to 20 , sessile, united in a flat, radiated crown, on the summit of the ovary; capsule obovoid, with imperfect partitions, opening by chinks, or pores, under the edge of the stigmatic crown.

\section{P. DUBIUM. Lim. Fie!d poppy.}

Leaves pinnatifid, hairy; peduncles clothed with appressed bristles; capsules clavate, smooth.

Annual. Stem 1 to 2 feet high, somewhat branching; leares 2 to 5 inches long; flowers dull red, on flexuous peduncles 6 to 12 inches in length, nodding before they expand.

Hab. In fields. Exotic. May. July.

Obs. This little foreigner is rather pretty in the fiower garden, but looks out of place in fields of grain and clover.

In such locations, hand weeding seems to be the only available means to eradicate it. It being an annual, the high cultivation of the grasses, will very much smother it out. The plant so much cultivated for the production of opium, belongs to this genus.

\section{Genus IV. ARGEMONE-Lim}

Sepals mostly 3 , aculeate; petals 4 to 6 ; stigmas 3 to 6 ; sub-sessile, radiately reflexed; capsule muricate, 1 celled, opening at apex by 3 to 6 valves; - seeds reticulate, with the raphe naked.

\section{A. MIEXICANA.-Linn. Prickly Poppy.}

Leares blotched with white, obovate-oblong, sinuatelobed, with prickly teeth; juice yellow.

Annual. Stem about 2 feet high, branching; leaves 3 to 5 inches long, sessile, and sub-amplexicaule; flowers yeliow, on leafy peduncles, or branches; sepals cucullate at apex, and terminated by a stont spine.

Hab. About gardens. Fl. June. Fr. Aug.

Obs. This coarse and forbidding Mexican weed has become very common, further south, and has extended its migration to A frica, Asia, and the South Sea Island. It is not very common with us, but without close watching may yet cause us much trouble. When plants possessing such familiar habits, are introduced into the flower garden, great care should be taken that they do not exceed their allotted bounds.

\section{Order IV. CRUCIFER P.}

Herbs with a pungent, watery juice; leaves alternate without stipuies; flowers corymbose, or racemose; pedicels without bracts; supals 4, deciduons; petals 4, cruciate; stamens 6, tetradynamous; fruit a silique or silicle; seeds without albumen; embryo mostly curved; the cotyledons bant over, with either their edge, or back, to the radicle.

\section{Tribe 1. CAMELINERE}

Silicle obovoid, or obiong; septum broad, parallel with the valves; cotyledons plane, incumbent, contrary to the septum. 
Genus V. CAMELINA.-Crantz.

Silicle obovoid, or pyriform, turgid, mucronate, dehiscent, and splitting the style; seeds numerous, oblong, not margined.

\section{C. SATIVA.-Crantz. Wild Flax. False Flax.}

Leaves oblong-lanceolate, sagittate, sessile; silicles inflated, marginerl.

Annual. Stem 2 feet high, paniculate at summit, leaves 2 to 4 inches long; racemes corymbose-paniculate elongating; flowers pale-yellow, inconspicuous; style about half as long as the silicle, persistent, splitting with the dehiscent ralves; seeds reddish-yellow.

Hab. In fields. Exotic. June. July.

Obs. This was once a common weed among flax; and by baing often thrown down when gathering the crop, the soil became so filled with it, as in some localities, to cause much trouble. It was long, a vulgar notion that this plant, and the flax-vine (Cuscuta epilina) were both degenerate flax, and liable to be produced, at any time, by the application of ashes to the soil. I learn that it has become very troublesome in the northwestern parts of this, or the adjoining parts of Lancaster county.

\section{Tribe 2. LEPIDINEZE.}

Silicle compressed contrary to the narrow septum; valves strongly boat-shaped, or keeled; cotyledons plane, mostly incumbent, parallel with the septum.

\section{Genus VI. CAPSELLA.-Vent.}

Silicle obcordate-truncate; valves not winged; seeds numerous, oblong; cotyledons incumbent.
6. C. BURSA PASTORIS.-Moench. Shepherd's Purse.

Radical leaves mostly pinnatifid, stem-leaves sagittate, sessile.

Annual. Stem 4 to 18 inches long, often branched, more or less hirsute; radical leaves 2 to 8 inches long; racemes at first corymbose, finally much elongated; flowers white.

Hab. Fields and gardens. Exotic. April. June.

Obs. Being an annual it is only necessary to prevent the seeds from ripening. High farming is the remedy.

\section{Order V. HYPERICACEZE}

Herbs, or shrubs, with a limpid or resinous juice; leaves opposite, entire, punctuate, without stipules; flowers regular, hypogynous, polyadelphous; petals mostly convolute; capsules 1 celled, with 2 to 5 parietal placentie, and as many styles, or 3 to 5 celled, by the meeting of the placente in the center; dehiscence septicidal; seeds numerous, with little, or no alburien.

\section{Genus VII. HYPERICUM. $-\operatorname{Linn}$.}

Sepals 5, nearly equal; petals 5, oblique, or unequal sided; stamens mited in 3 to 5 parcels, without interposed glands; capsule 1 to 3 , or 5 celled; flowers yellow. Herbs or shrubs.

\section{H. PERFORATUM-Linn. St. John's Wort.}

Stem somewhat ancipital; corymb-paniculate, leafy; leaves linear-elliptic, sessile; styles diverging.

Per-annual. Stem 1 to 2 feet high, often several from the same root; leaves an inch, or inch and half long, 
rather obtuse, with numerous pellucid, puncture-like perforations.

Hab. In grass fields. Exotic. June. July.

Obs. Dr. Darlington says of this worse than worthless weed--" It was formerly supposed to be the cause of scabs, and cutaneous ulcers, among cattle; especially, white cows, and horses, and those with white feet, and noses. The fact was taken for granted, by the farmers; but it must be confessed, that although the plant continues to be abundant, the disease has nearly, if not entirely, disappeared. It may be worthy of remark, that in the year 1842, the St. Jolm's Wort failed, entirely, to make its appearance, (in this comnty, and I believe, throughout Pennsylvania), even in fields where it had been most abmulant. The succeeding year, it was quite rare, but has since become about as common as ever, in neglected fields. Why a perennial plant should have been thus affected, seemed rather mysterious."

My observations do not exactly coincide with those of my friend. In 1841 there was a field in the Toughkenamon Valley, in which the grass had failed. As the summer advanced, one half of the field was so overorown with this weed, as to be quite a conspicuous object, at the distance of half a mile, from its bright yellow color. When the ficld was mowed, in that portion, the swaths were of respectable size, but were not thought worth gathering. Here were acres, closely set with perennial roots; but in the next scason (1812) not a plant was seen to spring up. Nor has there ever been any appreciable quantity up to the present time; either in that field, or in the surrounding neighborhood. Our good housewires have hardly been able to find enough St. John's Wort, for the last 30 years, to keep up a supply of "Reul Oil" for their corns, and burned fingers. May not the farmers have been right? And may not the disease of whiteskinned animals have disappeared, only as the producing cause ceased to operate?

This noxious weed, cannot always be made amenable to the scythe, and the plough. In grass, the seed, too often ripens before it is cut. It may still be hand pulled and may be very much crowded out by promoting a thick, and vigorous growth of grass. 'Try it.

There are two or three other objectionable species in this order; but to become acquainted with one is to know them all.

\section{Order VI. CARYOPHYLLACER.}

Herbs; stems nodose, usually tumid at the nodes; leaves mostly opposite, and entire, often sub-connate, rarely stipulate; flowers symmetrical, terminal, of 4 to 5 parts, the petals sometimes wanting; stamens as many, or often twice as many, as the sepals; styles 2 to 5 ; capsule 2 to 5 valved; seeds attached to the base, or central column of the capstile; embryo curved around the outside of mealy albumen.

\section{Sub-order 1. Silenex.}

Sepals united into a tubular calyx; petals 5 , each with a long slender claw, inserted, with the stamens on the stipe (corpofore) of the ovary; capsule partially 2 to 5 celled; stipules none.

* Caly 5 toothed; petals sometimes crowned.

Genus VIII. SAPONARIA.-Linn.

Calyx cylindric ; stamens 10 ; styles 2 ; capsules partly 2 celled at base, opening with 4 teeth, at apex. 
8. S. OFFICINAIIS.-Linn. Soap-wort

Leaves oval-lanceolate; flower's in corymbose fascicles; petals crowned at throat.

Per-annual. Stem 12 to 18 inches high; leares an inch and a half to 3 inches long; flowers pale red, or reddish white; often becoming somewhat double.

Hab. About gardens. Exotic. July. August.

Obs. None but the negligent need to suffer from the incursions of Bouncing Bet upon their precincts.

* Calyx with 5 elongated, foliacious segments.

\section{Genus IX. LYCHNIS.-Tourn.}

Calyx ovoid-oblong, coriaceous ; stamens 10 ; styles 5; capsule half 5 celled, opening with 5 or 10 teeth at summit.

\section{L. GITHAGO.-Lam. Cockle. Rose Campion.}

Iairy ; leaves lince-linear, acute; petals obovate emarginate, not crowned.

Anmual. Plant greyish, or glaucous green. Stem 2 to 4 feet high, dichotomously paniculate at summit; leares 3 to 5 inches long sessile, comnate by a scabrous membrane; flowers violet purple, on stout leafless peduncles, 4 to 8 inches long.

Hab. Fields, among wheat. Exotic. June. July.

Obs. Though diligently rooted ont by all neat farmers, this foreigner obstinately maintains its ground in our grain fields. The remedy is vigilance. Thoigh it is given as an annual plant it assumes to be bi-annual in our fields.

The means for its destruction are:

1. Sow clean seed.

2. Eradicate the plants as they appear. This may be very effectually done in early spring. Those which remain should be carefully pulled, as the hlossoms make their appearance. Do not, by any means "let both grow together; until the harvest." The parable was not intended for the Lychnis githago. If left till harvest the seeds are ripe, many of them are shed, in the field, where they remain in the soil, patiently awaiting the rotation of another wheat crop; while those taken to the barn remain among the wheat, or perinaps fall into the barn-yard to be returned to the field.

For forty years it has been my lot to inherit, after indolent cultivators; and to contend against the weeds which they had planted. I found it very convenient to have-and was seldom without-a brush-heap, as a place of deposit for seeding weeds; where they could be occasionally burned. Let every farmer do likewise.

\section{Order VII. PORTULA'CCACERE.}

Herbs; leaves entire, succulent; flowers regular, but unsymmetrical, viz., the sepals fewer than the petals; stamens opposite the petals, or more numerous; capsule 1 celled, few, or many, sceded; embryo curved around mealy albumen.

\section{Genus X. PORTULACCA.-Tourn}

Sepals 2, united, and adhering to the ovary, below petals mostly 5 , perigynous; stamens 8 to 20 ; styles 3 to 6 , or 8, united at base; capsule circumcised, many seeded.

10. P. OLERACEA.-Linn. Common or garden Purslane. Prostrate, smooth; leaves cuncate oblong, obtuse; flowers sessile. 
Annual. Stem 6 to 12 or 15 inches long, terete, fleshy, purplish, branched; leaves half an inch, to an inch iong, thickish, and flesly, sub-sessile, alternate and opposite; flowers yellow, in small clusters, axiilary, and terminal.

Hab. Garden, cultivated grounds. Exotic. July. Sept.

Obs. This humble intruder, is rather late in coming; but compensates for the loss of time, by a precocious development of flowers, and speelly maturation of seeds, in a continuous succession, as long as life continues. So great is the succulence of the Purslane that it will continue to perfect its seeds long after separation from its parent root. A day's sun will hardly wither the plant, but may ripen and shed many of its seeds. When pulled, or hoed, the inference is to remove it, immediately to a safe place of deposit. Hogs who are kept penned eat it eagerly.

\section{Order VIII. MALVACEXI.}

Herbs, or shrubs; leares alternate, stipulate; flowers regular; the calyx ralvate; the corolla convolute, in the bud; stamens numerous, monadelphous in a column, the anthers 1 celled, veniform; seeds with little albumen; embryo curved, the foliaceous colyledons variously doubled up.

* Calyx naked at base.

\section{Genus XI. ABUTILON.-Toum}

Carpels mostly numerous, verticillate, and coherent, forming a compound capsule, spreading at summit, where each splits open along the imer edge; seeds about 3 in each carpel.

11. A AVICENNA.-Gertn. Indian Mallow. Velvet-leaf.

Leaves orbicular-cordate, acuminate, velvety; peduncles axillary, shorter than the petioles.

Anmual. Stem 2 to 5 feet high, branched; leaves 4 to 6 or 8 inches long, nearly circular, with a closed sinus, and slender acumination; petioles 3 to 5 inches long; stipules subulate, caducous; flowers yellow ; carpels about 15 in a eampanulate, truncate head, with oblique, radiating beaks at summit.

Hab. Cultivated gromnds. Exotic. July. Aug.

Obs. This large, troublesome weed, being an annual may be readily kept in subjection. But the attempt often fails from the negleet of very small plants, which in this species, frequently produce seed when only a few inches high. When permitted to mature the plant is very prolific. It is a reproach to any farmer where it is found.

\section{Genus XII. SIDA.-Linn.}

Carpels 5 or more, 1 seeded, separable at maturity, each opening at summit; flowers perfect.

\section{S. SPINOSA.-Linn. Spinoze Sida.}

Leaves ovate-linceolate, with a sub-spinous tubercle at the base of the petiole.

Annual. Stem 9 to 18 inches high, slender, with a few spreading branches, near the base; leaves about 2 inches long, serrate-dentate; petioles half an inch, to three quarter's in length; stipules filiform; flowers yellow; peduncles about half an inch long, 1 to 2 in each axil, articulated near the flower.

Hab. Road sides. India. July. Sept.

Obs. This small wiry looking weed, is entirely worthless, and should not be parinitted to increase. I have 
recently seen it quite injurious to a potato crop, from sheer negligenre.

* Calyx involucellate at base.

\section{Genus XIII. MALVA.-Linn.}

Involucel mostly of 3 linear bracts ; carpels numerous, verticillately arranged in a depressed orb, each mostly 1 seeded, and indehiscent.

\section{M. ROTUNDIFOLIA.-Limn. Running Mallow.}

Procumbent; leaves cordate-orbicular, obtusely 5 lobed, lobes crenate-dentate; flower's small.

Per-annual. Stem 9 to 18 inches long, branching only from the root; leaves 1 to 3 inches long; petioles 2 to 6 or 8 inches in length; flowers reddish-white, with purple veins; peduncles axillary, mostly in pairs, 1 to 2 inches long, mnequal bent down in fruit.

Hab. Yards and fields. Europe. May. Aug.

Obs. This tronblesome weed is frequent about farm building, reaching to the garden, and cultivated lots. In such plices, when allowed to shed its seed, it requires the active use of the hoe, to eradicate it.

\section{Order IX. ANACARDIACE}

Shrubs and trees; with a resinous, or milky, acrid juice; leares alternate, mostly compound, without stipules ; flowers regular, pentandrous, small, often polygamo-dioicous; ovary (by abortion) 1 celled, and 1 ovuled, but with 3 styles, or stigmas; seeds without albumen.

\section{Genus XIV. RHUS.-Linn.}

Sepals 5, connected at base, persistent; petals 5 , inserted with the stamens, on, or under the edge of a flatted disk; fruit small, a sort of dry drupe; common petioles enlarged at base, covering the buds of the ensuing year.

* Leaves odd pinnate.

f Young branches smooth.

14. R. GLABRA.-Linn. Common Sumach.

Leaflets lance-oblong, acuminate, sertate, whitish beneath.

Per-annual. Juice copious, milky; stem 3 to 8 feet high, irregularly branched, branches stont, with a large pith; leaflets 2 to 4 inches long, 10 to 15 pairs with a terminal one, turn to crimson in autumn; flowers yellowishgreen, in dense, ovoid, terminal, panicles; fruit densely villous, finally bright purple, and sharply acid.

Hab. Fields and fence-rows. June. Sept.

Obs. This stragchling, unsightly shrub still holds a place in the neglected fields of slovenly, would-be farmers. The biris probably disperse the seeds, as seedling plints may quite frequently be met within the grounds of tidy agriculturists.

A closely allied species, R. Copallinum Linn, sometimes called dwarf sumach, thongin often taller than R. Glabra, is frequently seen in unimproved lands.

\section{R. VENENATA.-D.C. Swamp, or Poison Sumach}

Leaflets obovate-oblong, abruptly acuminate, the margin very entire, and slightly revolute.

Juice resinous; stem 10 to 20 feet high, branching above; leaflets 2 to 3 inches long, 4 to 6 pairs, with a terminal one; flowers grecnish, in sub-t.rminal, and axillary 
panicles; frnit smooth, and shining, pale yellowish-green, larger than in any of the preceding.

Hab. In swamps, and watery places. June. Sept.

Obs. This grows to be quite a tree. Its extremely poisonous properties renders it necessary that all should know it. For the want of this knowledge, many severe accidents have occurred

* Leaves ternate.

\section{R. TOXICODENDRON.-Lim. Poison Vine. Poison Ivy.}

Per-annual. Stem erect, or climbing by radicles; leaflets obliquely orate, or rhomboid, acuminate entire, or angularly dentate.

Juice resinous; in the erect variety (Poison Oak), 2 to 6 feet high; with leaflets larger, and variously toothed, or lobed. In the climbing variety, the stem reaches 50, perhaps a 100 feet, ascending tall trees by means of rootlets; leaflets 3 to 5 inches long; flowers yellawishgreen, in slender racemose, axillary panicles; fruit dry, smooth and shining, pale brown.

Hab. Woods, fencerows. May. Sept.

Obs. Though less virulent than the preceding species, it is capable of poisoning many persons severely, and ought to be sedulously extirpated from fields and fences.

Very many persons, not diseriminating between them, confound the poison vine with the American ivy (Ampelopsis quinquefolia). The distinction is rely obrious. The poison vine has ternate leaves, that is 3 leaflets on the common petiole; while the American iry has quinate leares, that is 5 leaflets on the common petiole.

\section{Order X. ROSACEA.}

Trees, shrubs, or herbs. Leaves alternate, stipulate; flowers regular; stamens distinet, inserted on the calyx, mostly numerous; pistils 1 to many, free, or combined with the calyx tube; seeds 1 or few in each ovary; without albumen ; radicle straight.

\section{Sub-order. Rosaceze proper.}

Herbs, shrubs, or trees; leaves simple or componnd; ovaries many or few, rarely single, free from the calyx, but sometimes included in its persistent tube; fruit either follicles, akenes, or little drupes; styles terminal or lateral.

\section{Tribe. Dryadeæ}

Pistils becoming dry akenes, or sometimes little drupes, in fruit; when numerous, collected on a conical, or hemispherical, receptacle, calyx-tube dry, segments mostly valvate.

\section{Genus XV. RUBUS.-Limn}

Calyx 5 parted, without bractlets at the clefts; petals 5 ; stamens numerous; pistils crowded on a convex, or oblong, spongy receptacle, and becoming small drupes; leaves mostly compound; flowers generally white, and the fruit edible. Perennial suffruticose plants.

* Fruit ovoid, or oblong, persistent on the juicy receptacle; leaves pedately 3 to 5 foliate.

$$
\text { † Stem erect, armed with stout prickles. }
$$

\section{R. VILlosus.-Ait. Common Blackberry}

Stems angular; young branches, and racemes, glandu- 
lar-villose; leaflets ovate, and lance-oval ; racemes many flowered.

Bi-per-annual. Stem 3 to 8 feet high, stout, ridged or obtusely angled, branching; leaflets 2 to 4 inches long: racemes rather large, sometimes leafy; fruit oroid oblong, or cylindrical, sometimes near an inch long, changing from green to red, or purple, finally black.

Hab. Fields, woods, \&c. May. July.

Obs. To those who have a place for every thing, and can keep every thing in its place, the blackberry brier is a valuable acquisition; but when out of place it comes to be a great nuisance, and requires careful eradication. Although al! persons must have had some knowledge of this weed scratched into them, yet very many have not yet learned a peculiarity in its habits, not often observed in other genera. While the root is per-annual the stem is strictly bi-annual. 'The canes of last year produce their fruit in this, and provide a successor for the next. It is bi-per-annual.

+ Stems procumbent; prickles shorter.

\section{R. CANADENSIS.-Limn. Running brier. Dewberry.}

Stems trailing, fruticose, smoothish; leaflets ovate, acute, thin ; fruit large, sweet.

Per-annual. Stem 3 to 10 feet long, slender, often several from the same root, running in different directions and giving off numerous, pubescent, leafy, flowering branches, which are nearly erect, and 2 to 6 inches hight; leafle's mostly ternate, an inch to inch and half long; flowers somewhat corymbose on the short branches; fruit oblong, or roundish, half to near an inch in diameter, black when mature, and very sweet.
Hab. In fields. Very common. May. July.

Obs. Of the fruit of the Running brier there is not much complaint; but the brier, when once established, is a great pest to the farmer, rendered doubly so by the difficulty of exterminating it. Why this difficulty? Let us see. The farmer ploughs his field, expecting to kill the briers; but they grow among his corn. He again ploughs, and they grow among his oats. He ploughs once more, and they grow among his wheat. And they continue to grow among the succeeding grass; perhaps more inmmerous than before. Why so? Not, I believe, owing to any unusual tenacity of life in the root, but first to the ploughing. 'With a dull share, and shallow furrow, the plough will probably run round more roots than it will cut off, and the rumners will be left buried in the soil; they were plonghed down, instead of up, which was a grave mistake. Secondly, to the faculty of the detached stems to take root, when properly buried in the soil. This planting is very neatly done by the plough; a stem is caught and stretched on the land side, its whole length, and the next bout buries it under the furrow-slice, where the after tillage camnot drag it out. The plain inference is that the stems should be removed before plowing; and the roots after that process. Good tillage, and hand digging before ploughing is the true method.

\section{Tribe Rosez}

Pistils numerons, inserted on the hollow receptacle, which lines the fleshy calyx tube; calyx segments imbricated, often foliaceous at apex.

Genus XVI. ROSA.-Tourn.

C.lyx-tube ureaolate, finally barry-like; petals 5; 
stamens numerous, inserted with the petals, on the rim of the caly $x$-tube; styles nearly included; ovaries distinct, hirsute, becoming bony akenes; leaves odd-pinnate; stipules adnate to the petiole. Shrubby, and prickly.

\section{R. CARoLinA.-Linn. Swamp Rose.}

Stem-prickles stout, recurved; flowers in terminal corymbs.

Per-annual. Stem 4 to 6 feet high, with numerous purple branches; leaflets mostly 5 or 7,1 to 2 inches in length, generally elliptic-lanceolate; flowers red, or purplish; fruit (that is the fleshy, or berry-like calyx tube, called a hip) depressed globose, somewhat glandular-hispid, dark red, and shining, when mature.

Mab. Moist grounds. June. Sept.

Obs. It lacks the enchantment of the rose, but possesses the repugnance of the brier; let it be rooted out.

\section{Order XI. ONAGRACEA.}

Herbs; leaves alternate, or opposite, simple, withont stipules; flowers mostly tetramerous ; caly $\mathrm{x}$-tube adherent to the 2 celled ovary, its lobes valvate in the bud, or obsolete; petals convolute in the bud; stamens as many, or twice as many, as the petals, or calyx-lobes.

\section{Sub-order. Onagracee proper}

Calyx-tube often longer than the ovary, bearing the petals (when present) and stamens, on its summit; stigma 2 to 4 lobed or capitate; capsule loculicidally 4 celled, and 4 ralved, or indehiscent; placentæ in the axis; seeds without albumen.

* Petals 4 ; stamens twice as many.
Genug XVII. OENOTHERA.-Linn.

Calyx-tube longer than the ovary; petals mostly obcordate; anthers linear, incumbent; pollen viscid; capsule oblong, or clavate; seeds not comose; leaves alternate.

\section{O. BIEN NIS-Linn. Evening Primrose.}

Stem stout, green; leaves ovate-lanceolate, repanddentate; capsule oblong, obtusely 4 angled, sub-sessile.

Annual. Stem 3 to 6 feet high, branched, often roughhaired; leares 2 to 6 inches long, lower ones short-petiolate, upper ones sessile; flowers large, in a terminal leafy, or bracteate spike, yellow ; calyx colored, tube cylindrical, 1 to 2 inches long, limb divided, reflexed, the segments partially cohering, and turned to one side, the $\operatorname{limb}$, and tube, above, the ovary, caducous; capsule an inch to inch and half long.

Hab. About gardens. July. Sept.

Obs. This rather coarse plant often escapes from the garden and becomes an unsightly weed; especially as its flowers never expand until the shades of evening, and close, never more to open. before another day. It is nevertheless a curious and interesting sight, to stand by, and witness the rapid expansion of the flowers, one after another, in the evening twilight.

\section{Order XII. CUCURBITACEA}

Herbaceous, mostly succulent, vines, with tendrils; leaves alternate, palmately veined, or lobed; flowers monoicous (sometimes dioicous); calyx-tube adhering to the 1 to 3 celled ovary; petals 5 , more or less united, often completely so; stamens 5 or 3 , somewhat united, as well by their tortuous anthers, as by the filaments; fruit 
(Pepo) usually fleshy, sometimes woody, or membranaceous; seeds large, without albumen.

* Petals connected only at base.

\section{Genus XVIII. SICYOS.-Linn.}

Calyx campanulate; fruit ovate, compressed, dry and membranous, 1 seeded, beset with barbed prickly, bristles, in capitate clusters, climbing.

\section{S. ANGULATUS.-Linn. Wild, or single-seed Cucumber.}

Leaves angulate - 5 lobed, cordate at base ; fruit prickly, and villous, in small dense, pedunculate clusters.

Annual. Tiscid-pubescent; stem 10 to 20 feet long, slender, branching; tendrils somewhat umbellately branched; leaves 3 to 5 inches long, and about as wide; peduncles 2 to 3 inches long; flowers greenish-white, clustered on axillary, common peduncles 1 to 4 inches long; the staminate ones corymbose-capitate, with the common peduncle longer; the pistillate ones in dense capitate clusters; fruit compressel, ovate, in stellately globose heads, an inch in diameter, armed with slender tawny spines.

Hab. About old gardens. July. Siept.

Obs. An unwelcome vagrant from the gardens which requires to be closely watched whererer it may occur.

\section{Order XIII. UMBELLIFERAE}

Herbs; flowers in (usually involucrate) umbels; calyxtube entirely adherent to the ovary; petals 5 ; stamens 5 , inserted (alternately) with the petals, on the disc that crowns the ovary, and surrounds the base of the 2 styles; fruit consisting of 2 seed-like dry carpels; seeds solitary, suspended; embryo minute, in the apex of copious horny albumen; stems usually hollow ; leaves alternate, generally much dissected, exstipulate, but the petioles more or less dilated, and sheathing at base.

\section{Sub-order, ORTHOSPERM}

Inner face (commissure) of the carpels straight and flat $\S$ Umbels perfectly compound.

a. Fruit beset with bristly prickles; carpels scarcely compressed.

\section{Genus XIX. DAUCUS.-Tourn}

Calyx 5 toothed; corolla irregular ; fruit ovoid-oblong, primary ribs slender, ciliate; secondary ribs .winged, bristly-pectinate, each covering a single vitta ; leaves multifid; umbels finally concave, involucrate.

\section{D. CAROTA.-Linn. Garden, and Wild Carrot}

Stem hirsute; leaves bi- or tri-pinnatifid; involucre nealy as long as the umbel.

Bi-anmual. Plant grayish-green, pilose; root fusiform, fleshy and yellow, under culture; stem 2 to 4 feet high, slender, branched; leaves much incised, segments 1 inch long; petioles 1 to 2 inches long, suleate above; umbels on long naked peduncles, flat, becoming concare in fruit; flowers whitish, or tinged with purple; the central floret often dark.purple, and abortive; fruit very hispid, the prickles on the secondary ribs, somewhat barbed.

Hab. Gardens, field. Europe. July. Sept.

Obs. In its wild state everyborly must know and detest this vile foreign intruder, and it will be well for us to consider how it can be most successfully eradicated. It is a bi-annual plant (in cultivation I have had it produce 
seed the first year and scatter them in the adjoining grounds), consequently is best destroyed in the second, or flowering season. Hand-pulling, as fast as it produces flowers is the most, perhaps the only reliable means. Cutting will not answer the purpose fully, for such is the vitality of the roots, that if cut at any time before the fruit is matured, they will throw up shoots and ripen other seeds. This may occur among second crop clover, unobserved.

When you have pulled the carrot, or indeed any other noxious seeding plant; never throw it on the public highway, where the rains may carry it upon a neighbor. Never throw it in streams of water for a similar reason. Never throw it in a damp place, or in a heap where it will not speedily wither and die; lest it should ripen seed and defeat the important object in view. This is often seen in the Dock and the Mullein. With all such untrustworthy weeds, the only safe place of deposit is on a brusth-heap, as I have mentioned under the head of Tychnis. With these precautions, you may secure success for your own labor; and perhaps aroid the infliction of a palpable wrong upon a neighbor.

If the seed of the common Parsnip did not so readily lose its vitality, I can see no reason why it might not soon become as great an agricultural pest, as the Carrot.

b. Fruit smooth.

* Carpels dorsally much compressed.

$\dagger$ Margins of the fruit single-winger.

Genus XX. HERACLEUM.--Linn.

Fruit broadly wing-margined; carpels slenderly 5 ribbed, the lateral ones close to the margin ; vittie clavate, shorter than the carpels.
Stout; leaves large, ternately dissected; petioles broad, and sheathing umbels large, flat; involucre few-leaved, deciduous; involucels many-leaved.

\section{H. LANATUM.- $M x$. Cow-Parsnip.}

Wooly; stem sulcate; segments of the leaves broad, palmate lobed, sub-cordate at base.

Bi-annual. Stem 4 to 8 feet high, branched above; segments of the leares 4 to 12 inches long, and as wide as long; the middle one often 5 lobed; petioles 1 to 4 inches long; umbels sometimes a foot or more in breadth, the rays 2 to 6 inches long; involncels of 5 to 8 leaves which are lanceolate with a long, slender acumination; flowers white.

Hab. Wet meadows. May. July.

Obs. 'This, and the two following, all coarse and conspicuons object, camnot fail to be observed by others, and must serve as an index of the neatness and attention of the owner.

\section{Genus. XXI. ARCHEMORA.-D. $C$}

Fruit broadly margined ; carpels with 5 equidistant obtuse ribs, the lateral ones dilated into the margin ; channels with single vitta; commissure with 2 or more vitue. Smooth per-annuals; leaves odd-pinnately dissecterl; the leaflets nearly entire, rather rigid; flowers white; involucre nearly none; involucels many-leaved.

\section{A. RIGIDA.-D. C. Cow's-bane.}

Stems terete, striate; leaflets 3 to 9 , oblong-lanceolate or sub-linear, often sub-falcate, sparingly incised-dentate near the apes. 
Per-annual. Stem 2 to 4 feet high, rathor slender, sparingly branched; leaves 2 to 4 inches long; petioles 1 to 6 inches in length; nmbels about 3 , on long perluncles; involucels of 6 or 8 subulate-linear leafless; fruit oval; channels filled to convexity, by the dark-purple vittæ; commissure slightly concave, lined with a white suberose coat.

Hab. Swampy pastures. Aug. Oct.

Obs. 'This plant is reputed poisonous to stock, as the common name signifies; and it probably would be, if they were to eat it; of which there seems but little dauger, so long as they have enough better pasture.

* Margins of the fruit doubly-winged.

\section{Genus XXII. ARCHANGELICA.--Hiffm.}

Fruit elliptic; carpels each 3 ribbed on the back, the lateral ribs dilating into marginal wings; seed separating from the coating; vitte numerous, often stout per-annuals, leaves bi-tri-ternately dissected; involucre scarcely any; involucels many-leared.

\section{A. ATropUrpUReA.-Hoffm. Purple Archangelica.}

Sten large, smooth, dark purple; leaflets unequally incised-serrate; umbels globose, smoothish.

Bi-annual. Stem 4 to 6 feet high, and 1 to 2 inches in diameter, hollow, and branching above; leaflets 2 to 5 inches long; ovate; pedicels very broad, and inflated; umbels finally globose, 6 to 12 inches in diameter; umbellets globose, 1 to 2 inches diameter; flowers greenish-white.

Hab. Low wet grounds. May. eTuly.

Obs. 'This very stout plant, as well as the smaller Archangelica hirsula should not be allowed to encumber pasture meadows along our larger streams.

\section{Sub-order. CAMPYLOSPERM}

Inner face of the carpels grooved length-wise; or margin turned in.

* Fruit neither prick!y, nor winged on the margin.

a. Umbels mostly without involucre or involucels.

\section{Genur XXIII. ZEGOPODIUM - Linn.}

Fruit oblong, crowned with the conical bases of the deflected styles; carpels with 5 slencler ridges, without oil-tubes; leaves ternate, or bi-ternate, with broad, pointed, scruted, leaflets; involucre, and involucels wanting.

\section{6. Æ. PODAGRARIA.- Iinn. Goats-foot, Ground-ash}

Root, creeping extensively ; stem robust, hollow, furrowed, glabrous; leaflets orate, or lanceolate, acuminate, unequally toothed; the lower leaves on long petioles; the upper merely 3 cleft; umbels m:my-rayed; petals white.

Per-annual. Stem 12 to 18 inches high; fruit very seldom perfected.

Hab. Garlens, fields, hedges.

Obs. "This, which is considered an exceedingly troublesome weed in England, has made its appearance in some parts of Pennsylvania, and proves to be a nuisance not easily abated. It has hitherto resisted all attempts to get rid of it."

Don, in his general system of gardening, \&c., says, that "being a great creeper, it cannot be achitted into gardens; for after it gets hold, it is next to impossible to eradicate it again." The leaves are said to be used in the same way as parsley; which accounts for Don's cautioning against its introduction. Such an invader should be carefully watched, and its spread arrested. I have no personal knowledge of this, and the following plant.

b. Inrolucre 3 leared; involucel none. 


\section{Genus XXIV. 五THUSA.-Lin.}

Calyx-teeth obsolete; fruit ovate, globose; carpels with 3 thick, sharply-keeler ridges; intervals with single oil-tubes; annual, erect, poisonous herbs, with 2 to 3 ternately compound, and many cleft leaves; involucre noine; involucels 1 to 3 leaved, flowers white.

\section{7. \#. CYNAPIUM.-Timn. Fools Parsley}

Segments of the leares wedge-lanceolate; involucel 3 leaved, long and narrow.

Annual. Stem 1 to 2 feet high, not spotted; leaves with alternate lobes, linear-lanceolate; umbels terminal and opposite the leaves; rays very unequal, the longest scarcely an inch in length; involucels 1 sided; fruit nearly as broad as long, with very prominent ribs.

Hab. Garden lots. Europe. July. Sept.

Obs. This poisonous plant is naturalized in $\mathrm{New}$ Eugland; it somewhat resembles the Poison Hemlock (Conium maculatum), from which it is distinguished by its unspotted stem, the long, pendulous, one sided involucels, and the straight ridges of the fruit.

I possess no other knowledge of this, and the preceding, species, than what is here given from Prof. Thurbar's edition of Darlington's Agrieultural Botany, page 1.51. Both are noticed as weeds by English writers.

\section{Genus XXV. CICUTA.-Iinn}

Fruit sub-globose; carpels with 5 flattish, equal ribs; channels with single, prominent vitte. Smooth, marsh per-annuals. Leaves tri-temately dissected; involucre mostly none; involucels many leaved; flowers white.
28. C. MACULATA.-Lim. Water Hemlock.

Stem spotted or streaked; leaflets ovate-lanceolate, acuminate, mucronately serrate, the nerves ruming to the notches.

Per-annual. Stem 4 to 6 feet hioh, branching striate with green, and purple, or yellowish-brown; leaflets 2 to 3 inches long, petiolulate; common petioles, often with a membranons margin, produced into 2 lobes, at summit; umbels terminal, and axillary; ribs of the carpels rather broad, the channels reddish brown filled with aromatic oily matter.

Hab. In swamps. July. Sept.

Obs. This coarse plant possesses a pleasant anisate odor; but the root is a deadly poison; and children perhaps deceired by the smell have sometimes eaten thereof, and paid the forfeit with their lives. There will always be safety in its early destruction. Being a peramnual and not spreading by the root, this will be easily effected. Let the grubber be employed.

\section{Genus XXVI. CONIUM-Lim.}

Fruit ovate, flattened at the sides; stylopodium flattened at the base; carpels with 5 equal, prominent, wavy-crenulate ribs; the inner face with a deep, narrow groove; vittie none.

Bi-annuals, leaves large, tripinnately decompound; involucre few-leaved; involucels halved, or milateral, about 3 leaved; umbels spreading, many rayed; flowers white.

29. C. Maculatum.-Jinn. Poison Hemlock.

Smooth, stem rather stout, tercte, spotted; leaflets 
lanceolate-pinnatifid; involucels shorter than the unbellets.

Bi-annual. Plant bluish-green, and sometimes, glancous; root fusiform, often forked, fleshy, white; stem 2 to 4 , or more feet high, branched, fistular, striate with green and yellow, often spotted with dark purple; fruit somewhat gibbous, crowned with the dilated base of the diverging styles; earpels with the faces inclining to separate, between the base, and apex; channels brown.

Hab. About gardens. Europe. June. Sept.

Obs. So far as my observations have extended, this highly poisonous plant was introduced into, and spread from, the larger botanical gardens of half a century ago. It appears too dangerous to man, and brute, to be tolerated, and had better be expunged, wherever it may occur.

DIVISION Ir. Gamopetalous Exogenous Plants

Floral envelopes usually consisting of both calyx and corolla; the petals more or Jess united.

\section{Order XIV. CAPRIFOLIACE}

Shrubs, rarely herbs; leaves mostly opposite, and without stipules; calyx-tube alnerent to the ovary; stamens usually, as many as the lobes of the corolla, and inserted on its tube; ovary 2 to 5 eelled; fruit berrylike, or capsular; embryo in the axis of fleshy albumen.

\section{Tribe SAMBUCER}

Corolla rotate, regular, and deeply 5 lobed; stigmas mostly 3 , sessile; inflorescence cymose, or thyrsoid.

\section{Genus XXVII. SAMBUCUS.}

Calyx-segments minute; fruit a globular, berry-like, juicy drupe, containing 3 to 5 seed-like nutlets; mostly shrubs, with large pith; leaves odd-pimately dissected; leaflets serrate, or laciniate; flowers white.

\section{S. CANADENSIS.-Linn. Common Elder.}

Leaflets 7 to 11, oblong, acuminate, smooth, petiolulate; eymes flat, 5 parted ; fruit purplish black.

Per-annual. Stem 5 to 10 feet high, suffruticose, and finally, woody. nodose, branching; leaflets 2 to 4 inches long, usually 3 pairs and an odel one.

Hab. Fence-rows, thickets. June. Aug.

Obs. This impudent, and intrusive loafer, is too exacting, and too filthy in his habits to he tolerated by any respectable agriculturist. Mappily the timely, and eflicient use of the grubbing hoe will soon abate the nuisance.

\section{Order XV. DIPSACEA}

Herlos. Leaves mostly opposite, without stipules flowers in dense, involucrate heads; calyx-tube adhering to the ovary, the border entire, or toothed; corolla tubular, 4 to 5 lobed; stamens mostly 4, distinct; styles filiform; stigma simple; fruit akene-like, 1 celled 1 seeded; seed pendulous; embryo nearly as long as the fleshy albumen.

\section{Genus XXVIII. DIPSACUS.--Tourn.}

Involucre many-leaved, longer than the bracts, (or subfoliacious chaff) of the receptacle; florets each with a 4 : sided ealyx-like involucel, closely investing the ovary and fruit, border of the calyx, minute, cup-shaped, entire, corolla with 4 erect lobes.

Stout bi-annuals; leaves often comnate; heads ovoid- 
oblong, the florets commencing to open in a ring about the middle of the head, and proceeding in opposite directions.

\section{D. SYLVESTRIS.--Mill. Wild Teasel.}

Leaves lance-oblong, serrate; involucre longer than the head; bracts straight and flexible.

Bi-annual. Stem 3 to 5 feet high, branched, angular, prickly ; radical leaves 8 to 12 incies long, crenate, stem leaves 3 or 4 to 6 or 8 inches long, sessile, connate, all more or less prickly on the midrib, and sometimes on the margin; leaves of the involucre, unequal, lance-linear, curved upward, and inward, pungent at apex; heads of flowers, ovoid-oblong, 2 to 3 inches in length; corolla pale purple; bracts (or chafl of the receptacle), ohlongcuneate, keeled, abruptly tapering into a straight, flexible, awn-like, acumination, longer than the florets.

Hab. Fencerows. Europe. July. Sept.

Obs. In some instances this foreign weed has given a good deal of trouble for want of timely attention.

\section{D. FULLORUM.-Mill. Fuller's Teasə1.}

Leares obovate-oblong, the upper ones entire; involucre shorter than the head; bracts recurved at apex, rigid.

Bi-annual. Stem leaves, and general character, similar to the preceding; hearts of flowers elliptical; bracts (or chaff of the receptacle) terminating in a rigid, subulate, recurved, acumination.

Hab. Garden lots. Europe. July. Sept.

Obs. Cultirated (though less than formerly) for the flower heads. These are used by Fullers; the rigid recurved points of the mature bracts serving as a kind of card to raise a map on woollen cloth. As weeds there can be little choice between them. A little attention will prevent them maturing seeds.

\section{Order XVI. COMPOSIT}

Mostly herbs; leaves alternate, or opposite, often lobed, or dissected, never truly compound, not stipulate ; flowers in close heads, composed of many florets (perfect or imperfect) upon a common receptacle, and embraced by (mostly numerous) leaflets, or scales, which form a general involucre; calyx-tube closely adherent to the ovary; the limb, or border of the calyx (called pappus) consisting of hairs, awns, or scales, or sometimes obsolete ; corolla either tubular, and 5 lobed, or ligulate, and 5 toothed; stamens mostly 5 , inserted on the corolla, the anthers united, forming a tube round the style, which is two cleft at summit, with stigmatic glands, in lines, on the inner surface of the branches; fruit an akene containing a single erect seed destitute of albumen.

\section{Sub-order. TUBULIFLORAE}

Flowers of the disc tubular, mostly perfect-of the ray, (when present) ligulate, either pistillate or neutral.

\section{Tribe VERNONIACEA.}

Theads discoid; florets all alike, perfect, and tubular; style-branches slender, filiform or subulate, hairy all over; the stigmatic lines, only on the lower part.

\section{Genus XXIX. VERNONIA.-Schreb}

Heads many-flowered, in corymbose cymes; involucre shorter than the florets; the scales imbricated, and appressed; receptacle naked; akenes clavate, ribbed; pappus double; the inner, of numerous capillary bristles; the outer, short, and scale-like.

Per-annual; leaves alternate; flowers bright purple. $2 *$ 
33. V. NOVABORACENSIS. - Wild. Iron Weed.

Leaves oblong-lanceolate; scales of the involucre, mostly, with a long, filiform, flexuous point.

Per-annual. Stem 2 to 6 or 7 feet high, sulcate-striate, roughish-pubescent, branching above, hard and sub-ligneous; leaves 3 to 6 inches long, sub-sessile, serrate, roughish, and sub-coriaceous; akenes scabrous with short hairs.

Hab. Moist grounds. Aug. Sept.

Obs. A worthless, and troublesome weed in moist bottom lands; unless carefully disposed of. Being a rank per-anmual, the proper means is to destroy the root either by ploughing or grubbing. 'The grubber is much the most effective weapon.

\section{Tribe EUPATORIACE}

Style-branches obtuse, or clarate, usually elongated, pubescent on the outside: stigmatic lines below the middle of the branches; anthers not tailed at base.

\section{Sub-tribe. EUPATORIEA.}

ITeads discoid; florets all alike, perfeet, and tubular, usually purple, or white, almost never yellow; receptacle naked.

\section{Genus XXX. EUPATORIUM.-Toum}

Teads 3 to many flowered, mostly corymbose; involncre oblong, scales imbricated in 2 or more series, or sometimes nearly equal, in a single series; florets tubular, scarcely dilated at the throat; akenes.5 angled; pappus, a single row of' slender, roughish bristles; receptacle flat.

Per-anuuals; leaves mostly opposite, or verticillate, often resinous-dotted; flowers white, or purple.

* Heads 5 to 10 flowered; scales closely imbricated, in several series of mnequal lengths; leares rerticillate, petiolate, flowers purplish.

\section{E. PURPUREUM.-Linn. Purple Eupatorium.}

Stem stout, simple; leares 3 to 6 in a whorl, lance-oblong, or lance-ovate, serrate ; corymb large, compound.

Per-annual. Stem 4 to 6 feet high, fistular, smoothish and glaucous-purple, or solid, with pith, spotted, and inore or less pubescent; leares 3 to 8 inches long; petioles half an inch to 2 inches; heads of flowers in a terminal corymb, of varying size, and shade of color.

Hab. Moist grounds. Aug. Sept.

Obs. 'This is perhaps the largest, and most perspicuous of our Eupatoriums. Coarse but rather showy; and disposed to occupy too much space, both in the soil, and in the eye, to satisfy a neat farmer. He will of course order its removal. Like the preceding, its strong and numerous roots yield reluctantiy to any device short of the grubber.

** Heads 5 to 20 flowered; scales 8 to 15 , unequal, more or less imbricated; leares mostly opposite, sessile, sometimes connate; flower's white.

35. E. PERFOLIATUM.-Linn. Thorough stem. Bone-set

Leares oblong-lanceolate, connate-perfoliate, rugoseveinel, crenate-ser'ate, very pubescent beneath; scales of the involucre lance-linear, acute.

Per-annual. Stem 2 to 4 feet high, rather stout, corymbose at summit, hirsutely pubescent; the branches whitish, and very pubescent; leaves 4 to 8 inches long, more or less completely united at base, rarely ternate, minutely resinous-dotted, beneath; heads of flowers clustered in large corymbs. 
Hab. Low and swampy orounds. July. Sept.

Obs. This vely abundant rough weed, is variously known as Indian-sage, Bone-set, \&c., \&c., all locking to its medical qualities. 'To say nothing of its real virtues; there are those who believe that it will operate, either upwards, as an emetic; or downwards, as a cathartic; as the leaves may have been stripped off the stem, up or down. A remnant of ignorance, credulity, and superstition, which still inheres in many minds.

The plant is too coarse and too aggressive, to be long tolerated in decent pastures. Like many other' per-annual weeds, it requires the plough, or the hoe, for its eradication. Cutting can only save the seeding of the ground. When in flower, the stems are easily pulled of from the crown of the root; and from some recent experience, I have reason to believe, if tholonghly done, will cause the root to perish. If found to do so, this will be the appropriate remedy.

Several other species occur, which, if they prove troublesome should be treated in the same way.

I might here mention the beautiful and chaste Conoclinium crelestinum (or Blue Eupatorium), but it would be a shame to associate its delicate form, with mere weeds.

\section{Sub-tribe. ASTERINEA}

Heads mostly radiate; the disc florets perfect, and the ray florets pistillate; anthers not tailed at base; receptacle not chaffy, mostly flat, and alveolate, or punctate.

$$
\text { + Rays never yellow. }
$$

\section{Genus XXXI. ASTER.}

Heads many flowered; rays numerous, in a single series; involucre sub-campanulate; scales more or less im- bricated, with herbaceous, or sub-foliaceous tips; akenes usually compressed, cuneate, pubescent; pajpus simple, scabrous.

Mostly per-annuals; radical and lower leaves, often cordate, at base; heads of flowers corymbose, paniculate, or racemose; rays white, purple, violet, or blue.

* Scale-tips more or less spreading, and herbaceous.

†† Rays mostly white; heads small and numerous.

\section{A. ERICOIDES- - Linn. Eeath, or Field Aster.}

Diffusely branched; branchlets sub-secund; leaves spathulate-oblong, and lmear, nearly entire; involucre somewhat hemispherical, loosely imbricated; scales linearoblong, acute.

Per-annual. Stem 1 to 3 feet hich, smooth, or slightly pubescent, often quite bushy ; radical leaves 1 to 4 inches, sparingly serrate, ciliate, tapering to a long petiole; stemleaves 1 to 3 inches; those on the branches small, subulate-linear, acute at each end; heads of flowers small, numerous, solitary, on the ascending, somewhat secund, leafy, peduncles, or branchlets; rays tinged with purple; disc yellow; akenes minutely pubescent.

Hab. Poor, or neglected fields. Aug. Oct.

Obs. This is the most abundant of the Asters, and is quite aggressive on most soils when for any cause, the grass has been allowed to run out. The ground seems so stored with seeds, ready to spring up on any emergency, that a failure of the grass is supplied by the Heath Aster. The inferential rule would be, allow no more seed to ripen, and crowd out the plant by a full growth of grass, until the plough can be brought into requisition.

The physiognomical features of all our members of this 
large family, are so similar, that to become acquainted with one, is to know them all, except the large New England Aster (Aster nove anglia), which is thought to be wortly of cultivation as a flowering plant

ft+ Rays almost always yellow.

\section{Genus XXXII. SOLIDAGO.}

Heads small, and few flowered; rays about 5 in a single series; involucre oblong; scales generally appressed, and without herbaccous tips; akenes subterete, many-ribbed; pappus single, of equal papillary bristles; receptacle naked.

Per-ammuals; stems commonly virgate; leaves sub-sessile, never cordate; heads commonly racemose-paniculate.

* Racemes secund, spreading, or recurved.

† Meuds middle sized; plants cinereons-pubescent.

\section{S. NEMORALIS.-Ait. Field Solidago. Golden-rod.}

Stems often corymbose at summit; leares spathulateoblong, and oblanceolate, crenate-serrate, or entire; roughish-pubescent.

Per-annual. Stem 1 to 3 feet high; radical leaves 1 to 4 inches long, tapering to a petiole 1 to 3 inches in length; stem-leaves narrower, tapering almost to a petiole; heads of flowers in secund racemes, on recurved branches (often in axillary clusters); involucre smoothish, scales lance-oblong, oltuse; rays 6 to 9 , spathulateoblong; akenes pubescent with white hairs.

Hab. Sterile banks, field, dc. Aug. Oct.

Obs. This weed indicates, either a poor soil, or a poorer cultivator. It is easily cadicated by good tillage. This is true of the numerous other, and larger species, also. But along fences and where the plow cannot come, some of them are too ornamental, and do not correspond with modern ideas of neat firming. The tield fence corners camnot appropriately be used tor flower gardens.

\section{Tribe. SENECIONIDE平}

Style-branches linear, externally convex, hairy, or pencil-tufted at apex, either truncate, or produced into a cone or hairy appendage; the stigmatic lines te:minating at the base of the cone, or appendage, and not confluent; leares opposite, or alternate.

\section{Sub-tribe. MELAMPODINEA}

Florets all imperfect, staminate or pistillate, either in the same head, when the pistillate are in the border, or in separate heads; anthers without tails at base; pappus mostly none, sometimes 2 horned, never of capillary bristles; receptacle mostly chaffy.

\section{Genus XXXII. AMBRosia.}

Heads monoicous; the staminate ones 5 to 20 flowered, in terminal racemes; the pistillate 1 flowered in bracteate clusters of 2 or 3 to 5 , scssile at the base of the racemes, $\mathrm{Or}$ in the axils of the upper leares; involucre of the staminate heads, flattish, scales several, mited into a cup; florets all funnel-form; involucre of the pistillate florets turbinate, closely embracing the akenes, like a utricle, acuminate, with 4 to 8 (usually 5 or 6 pointed tubucles near the summit; corolla none; akenes oboroid.

Chiefly annuals; leares opposite, and alternate, petiolate, lobed, or jimatifinly dissected. 
38. A. TRIFIDA.-Linr. Tall Rag-weed.

Stem tall, stont, rough-hairy; leaves paimately 3 to 5 lobed, lobes oval-lanceolate.

Anmual. Stem 6 to 8 feet high, angular, branched; leaves 4 to 8 inches long, 3 lobed (sometimes undivided) opposite, hairy and scabrous, on slightly margined, ciliate petioles, about an inch long; staminate heads numerous, in long terminal, pedunculate racemes; florets whitish; involucre of the pistillate florets, strongly 5 to 6 ribbed, the ribs with as many acute points at top.

Hab. Low grounds. Aug. Oct.

Obs. This stately weed does not often intrude upon well tilled lands, like its congener, but often disfigures some nook, or fence row, in the meadow.

\section{A.ARTEMISSIIEFOLIA--Linn. Rag-weed Bitter-weed.}

Stem rather slender, and diffusely branched, villous and roughish; leaves bipinnatifid, the upper ones simply pinnatifid.

Hab. Fields everywhere. Aug. Oct.

Obs. This may very aptly be termed The Weed, as it seems to abound, more than any other, in our farm lands. It is apt to spring up wherever the surface has been broken; but seems to have a remarkable aptitude for the autumnal stubble fields. By the next season it is said that the grasses will smother, or choke it out. This is true to a great extent. But, either the ground must abound in the seeds of former years, or there must be a large addition to them, annually. Whether would it not be hetter to use the mower in all pasture and stubble lands where they abound, and thus effect two good purprisis, the clearing of the ground, and the destruction of the seed. But by all means do this before the possible maturation of the reproductive germs. This must always be made the sine qua non of the conflict with weels. I have seen the weeds, on a very foul farm, fully reduced to a moiety in a very few years, by such attention.

An aged, and highly respected housekeeper of a generation now passed away; confidently assured me that there had not a weed matured its seeds in her garden for seven years, and as a consequence. she was not much troubled by them in that department. Let our ambitious young farmers try it.

\section{Genus XXXIV. XANTHIUM.-Tourn.}

Heads monoicous, in spicate clusters, the staminate above, many-flowered; involucle of the staminate heads subglobose, scales distinct; florets elavate; pistillate heads 2 flowered, the involucre oblong, closed, coriaceous, armed with hooked prickles, and one or two, strong beaks at apex; corolla filiform; akenes oblong, compressed. Annuals; leaves alternate, petiolate, lobed or dentate.

\section{X. StrumariUM.-Linn. Clot-Bur. Cockle-Bur}

Leaves broad-ovate, somewhat 3 lobed; petioles not spinose at base; pistillate involucre with 2 strong, straight beaks at apex.

Annual. Stem 1 to 3 feet high, angular, branched scabrous-pubescent, leaves 3 to 6 inches in length, and nearly as wide as long, sub-cordate at base, but connately produced in the center at the junction of the 3 principal nerves; petiole 3 to 4 inches long; heads of flowers in axillary, racemose cluster's, the pistillate ones at the base of the racemes. 
Hab. Yards, roat-sides. Europe. Aug. Oct.

Obs. Prof. A. Gray considers this a native. Dr. Darlington calls it "an obnoxious weed, thongh not nuch inclined to spread, and with a little attention, is easily kept in subjection." I hope that others may find it so, I have not. But it does seem less common than it was 40 years ago, at least in some sections. Perhaps the sheep have not the same opportunities, they then had, to disperse the seets. Close mowing, before fruiting, with a little hand weeding, and proper care to burn the refuse matter, will meet the emergency very well.

\section{X. SPINOSUIVI-Linn. Thorny Clot-Bur}

Leares orate-lanceolate, hoary-tomentose beneath ; petioles triply spinose at base; pistillate involucre with a single inconspicuous beak, at apex.

Ammal. Stems 2 to 3 feet high, terete, striate, pubescent. branched; leaves 1 to 2 inches long, sometines 3 lobed, or with a lobe-like tooth on each side, narrowed at base, to a short, pubescent petiole, on each side of which, is a triple, or 3 forked, yellowis'r spine, the branches about an inch long, and very sharp; heads of flowers axillary, mostly solitary.

Hab. Waste places. Europe. Sept. Oct.

Obs. This execrable foreign weed has found its way into our county, but is, happily, yet rare; and it behoores every good citizen, to extirpate it, wherever it may appear. "Some years since, the authorities of one of our cities, where it was becoming a great nuisance, in the streets, enacted an ordinance against the plant; denouncing it by the name of the Canada Thistle. The misnomer, probably, did not impair the eflicacy of the ordinance; but it would be more reputable to all coneerned, if they could avoid confounding objects which are essentially distinct, and learn to designate even weeds by their proper names." I found this repulsive reed entrenched among the cliffs which border the Susquehamna at Port Deposit; more than 30 years ago; and cultivated it from seed then obtained. But I have not met with it nearer home. When invaded by stich a foe, every man should feel himself, an appointed guardian, and defender of his country's best interest, and battle nobly for its utter extermination. Associated efforts should be lrought to bear upon the labor, when it is too great for individuals to accomplish. United we stand, divided we fali; has a significance, far away from the arena of political strife, or murderous warfare. I have often dismounted from my horse, or carriage, to pull up some stray, noxious weed, which had gained a footing by the public highway. Such, for instance, as the Echium vulyare, or Tiper's Bugloss. If every agriculturist would do so, much prospective mischief would be anticipated, and prevented.

\section{Sub-tribe. FELIANTEER.}

Heads mostly radiate; dise-florets always perfect, anther's blackish, without tails at base; pappus none, or crown-form, or consisting of awns, of awn-like chaff, never capillary, nor of uniform, distinct chaffy scales; receptacle chaffy; leaves often opposite.

\section{Genus XXXV. BIDENS.-Linn.}

Heads, many (or sometimes few), flowered; ray-florets neutral, often few and inconspicuous, sometimes wanting; involucral scales in 2 series, the outer commonly, large, and foliaceous; akenes ob-compressed, or slender; and 4 
sided; pappus 2 to 4 or 5, rigid, persistent, retrorsely hispid awns; reeptacle flattish; chaff deciduous.

Mostly annuals; leaves opposite, penninerved ; flower's generally yellow.

\section{B. FRONDOSA.-Linn. Bur-Marigold.}

Leaves odd-pimnately divided, in fives, or threes, the leaflets lanceolate, serrate; akenes 2 awned, cilliate with erect hairs.

Annual. Stem 2 to 5 feet high, angular, branclier, sparsely pilose, often dark purple; leaflets 2 to 5 inches long. with short, margined petioles; common petiole 1 to 3 inches, margined; heads of flowers small, on long, naked, slender, axillary branches; involucre double, onter scales 8 to 12, foliaceous, mnequal, longer than the heads, cilliate at base; rays none; akenes obovate-cuneate, antrorsely cilliate; awns longer than the florets.

Hab. Garden lots, \&c. Aug. Oct.

Obs. A homely and troublesome weed. The akenes, of all the species, readily adhere to clothing by means of the retrorsely setose pappus, and prove themselves a great amoyance. Hand-weeding, and the judicious use of the seythe, are the proper means to abate it.

\section{B. BI-PINNATA.-Linn. Spanish Needles.}

Leaves bi-pimnately dissected, petiolate; rays about 3 , small; akenes 3 or 4 , awned, sublinear, sulsate, smoothish.

Annual. Stem 2 to 4 feet high, 4 angled, smooth, branched; leaves 2 to 5 inches long, deltoid-ovate, mostly cuneate-attenuate at base; petioles 1 to 4 inches in length; heads of flower's small, oblong, on long, naked, sulcate, angular, axilary, and terminal, peduncles; involucre double, scales connate at base, outer ones about 8, shorter and narrower than the inner ones; rays obovate, yellow with dark veins; akenes abont $\frac{3}{4}$ of an inch with erect hairs; pappus of 3 or 4 retrorse, hispid awns.

Hab. Gardens, lots, \&e. Aug. Oct.

Obs. This, as the form of the akene shows, is properly the Spanish Needle. But the name appears to be applied to the other species also, which do not present the needileform. 'They all indicate negligence in the cultivator.

\section{Sub-tribe. ANTHEMIDE五}

Heads radiate, or discoid, never dioicous; disc-florets sometimes abortive; anther's withont tails; pappus none or a very small crown; leaves alternate, often dissected.

† Heads of flowers radiate.

\section{Genus XXXVI. MARUTA-Cassini.}

Heads many flowered; ray-florets mostly nentral; involucre hemispherical; akenes obovoid, rihbed, pappus none; receptacle prominently convex, chaffy all over; or only at summit.

Fotid annuals; leares bi-tri-pinnately dissected.

\section{M. Cotula - D. C. Dog's Fennel. Stinlring Chamomile}

Involucral scales with whitish, scarious margins; receptacle chaffy at summit, only.

Annual. Stem 8 to 12 inches, mostly erect, leafi, bushily branched; leaves 1 to 2 inches long, subsessile, green, pinnatifidly dissected, segments linear, acute; heads of flowers terminal, on leafless peduncles; rays white; disc yellow; receptacle oblong-conical; chaff subulate, shorter than the florets. 
Hab. Yards, lanes, \&c. Europe. June. Aug.

Obs. This worthless, and stinking weed used to be quite common in onter yards, and lanes, around firm buildings; but a better appreciation of the olfactory sense, has led to its partial destruction.

\section{Genus XXXVI. ACEILLEA.Lin.}

Heads several-flowered; ray-florets few, and shortpistillate; tibe of the disc-fiorets ob-compressed, margined ; involucre obovoid-oblong; akenes ob-compressed, oblong, somewhat margined; pappus none; receptacle small, flatish, chaffy.

Peremials; leaves altemate, often pinnatifidly dissected; heads small, in flat dense corymbs.

\section{A. MILLEFOLIUM--tinn. Yarrow. Milfoil}

Stem mostly simple; leares bi-pinnatificl, the segments lineall, incised-serrate; rays 4 or 5 , romdish-obovate

Bi-per-annual. Stem 2 to 3 feet high, sulcate-striate, hairy, and somewhat lannginous, leafy ; leaves 2 to 6 inches long, subsessile, more or less pilose; heads of flowers numerous, fragrant; involucial scales with a prominent keel, or midrib; rays white, often tinged with purple; dise-florets whitish, the tube green, sprinkled with resinous particles; chafl of the receptacle, lance-oblong, acute.

Hab. Old pastures, \&e. Europe. June. Aug.

Obs. Whatever may be its dubious claims, as a medicine; or as a pasture producing plant in Europe; the Yarrow, with us, is a pernicious, and aggressive weed, in pasture grounds and lawns, not suliject to the plow. It send up numerous stems which frut abundantly, if not timely removed. As if not satisfiel with this; the root simultaneously forms a great many $r$ hizomes which radiate in all directions, and make their appearance, as so many off-sets from the parent plant. These come up 3 to 6 inches from the mother stem, as so many young plants for the next year's crop of seed. The fibrous roots from the ground-stems prevent them being effectually pulled, unless in locse light soils; necessitating the nse of the hoe. Early summer is the proper season for this work, before the formation of the rhizomes.

\section{GenUS XXTVII. LEUCANTHEMUM.}

Teads many flowered; ray-florets numerous, pistillate; disc-florets ob-compressed; involucre almost flat, spreading; scales with scarious margins; akenes all similar, subterete, striate, or ribbed, smooth; pappus none; reeeptacle flattish, naked.

Per-annuals. leaves mostly pimnatifid or incised-dentate; heads ratior large, solitary, and terminal; diseyellow; rays white.

\section{L. VULGARE-Lim. Ox-eye Daisy. White-weed}

Stems erect, or inclined, often numerous, nearly simple, ratlier naked above; ralical-leaves spathulate, petiolate; stem-leares oblong, sessile and clasping; all incised dentate; involneral scales with narrow russet-brown margins.

Per-annual. Stem 1 to 2 feet high, angular, somewhat hairy, purplish on the angles; leares 1 to 2 inches long; radical leaves on petioles 1 to 2 inches long; heads of flowers 1 to 2 inches in diameter; including the rays; akenes dark purple between the ribs.

Hab. Fields. Furope. June. Aug.

Obs. Wide as has been the dispersion of this vite pest; 
there are still many districts, of variable extent; many farms which have thus far been preserved from its incursions; the owners cf which desire to maintain their preemption right. Let these remember that "Eternal vigilance is the price of Liberty." Happily, the invader is sure to herald his approach, by deceitfully displaying a White Flag. While this need not to deceive, it must warn of the danger, and should lead to prompt, and vigorous resistance.

It is a more grave question for decision. How to eradicate the daisy from land which has long been infested with it? That it can be done, admits of demonstration. How best to do it? is a problem for the reason.

Several years ago I came in possession of a spot of ground, the eighth part of an acre of which was very stony. In addition to a few scrub sapplings, was a plentiful growth of hucklebery bishes, and briers; worse still, the daisy had obtained possession of it. I could neither dig, nor pull, the roots, nor now the plants. With no further object than to prevent the shedding of the seed; I carefully gathered all the flowering stalks, pulling them off from the crown of the roots. I was as much gratified, as surprised, to fund that those roots perished without further trouble. The same result has followed the same method many times since. But where any young stems, that have started, have been overlooked they will continue to grow, and a new crown will be formed. The fact should not be forgotten.

My neighbor W. C. found his farm so stocked with daisy (in 1862) that the fields were already white unto the harvest, long before the harvest was ripe. With two small boys, and a determined will, he so unremittingly applied the gloves, the scythe, and the hoe; in the fields, and in the highway, in every place where the plow could not be immediately brought to bear; that in a rery few years ( 8 or 10 ) there was comparatively very few White Flags to be seen on the premises. Why cannot others go and do likewise.

But it is not sufficient, that the White Flag-staff should be ent down, and the fag trampled in the dust. 'The farmer may industriously apply the glove-the hoe-the scythe-the plow; and do it with little advantage to himself; if he does not kNow and act in accordance with his knowledge-THAT THE DAISY (as well as someother weeds) RIPENS ITS SEED WHILE YET IN BLOOM. In other words, it retains its white petals long after the proper flowering season has passed; and time allowed for maturing the seeds. With a knowledge of this fact, every one must draw the practical inference-That the refuse matter must not be suffered to remain upon the ground; or be carelessly thrown in the fence-corners-bye places_or public roads; only to be returned to the fields in due season-but that it must be effectually destroyed. Here again, the brushheap and fire, may be brought into requisition successfully.

\section{Sub-tribe. SENECIONE王.}

Heads discoid, or radiate, never dioicous; marginal florets pistillate; anthers without tails, at base; pappus capillary, often soft, and white; receptacle mostly naked; leaves generally alternate.

\section{Genus XXXIX. ERECHTITES.-Raf.}

Heads many flowered, discoid, the florets all fertile; involucre cylindric-oblong, smooth; scales in a single series, linear, acute, with subulate bractlets at base 
akenes oblong, tapering at apex; pappus copious, soft and silky, very white.

Coarse annuals; leaves undivided; heads corymbosepaniculate; florets whitish, very slender.

\section{E. HIERACIFOLIA.-Raf. Fire-weed}

Smoothish; stem striate sulcate, often virgate; leaves lance-oblong, acute, sessile, the upper ones auriculate at base, and somewhat clasping, unequally dentate.

Annuals. Stem 2 to 5 feet high, stout, succulent, and tender, when young, paniculately branched, or occasionally subsimple, and virga:e; leaves 3 to 6 inches long; heads of flower's, in small cymose corymbs, terminating the paniculate branches.

Hab. Recent clearings. July. Sept.

Obs. Remarkable for its occurrence wherever brushheaps have been burned-hence its popular name. Cut it down.

\section{Tribe. CYNARE㞋.}

Heads discoid, usually large, sometimes dioicous; involucral scales imbricated in many series; style in the perfect floret, often nodosely thickened, near the summit, branches distinct, or concrete, puberulent externally, the stigmatic lines extending to their apex, and there confluent.

\section{Genus. XL. CIRSIUM.-Toum}

Heads many-flowered; florets similar, and perfect, or rarely, imperfectly dioicous; involucre roundish-ovoid; scales mostly tipped with a spine; anthers with a linearsubulate appendage; filaments often hairy; style-branches concrete nearly to the apex; akenes oblong, compressed; pappus of many hairs, mited in a ring, at base, plumose to the middle; receptacle fibrillate.

Bi, or, Per-annuals. Leaves alternate, mostly sessile, often pimatifid, and prickly; heads usually large, terminating the branches; flowers generally purplish.

+ Involucral scales, all tipped with a spreading spine.

\section{C. LANCEOLATUM.-Scop. Common Thistle.}

Leaves pinnatifid, decurrent, (forming a prickly, winged. stem) prickly-hispid on the upper surface, cobwebby beneath, the segments lanceolate.

Bi-ammal. Stem 2 to 4 feet high, stout, branching; leaves 4 to 10 inches long; the radical ones (as is usual with bi-annuals) much larger than the canline; heads ovoid, about an inch in diameter; florets purple; anthers yellowish.

Hab. Pastures, road sides. June. July.

Obs. This is bi-annual, and can readily be extirpated - by cutting it up with the hoe in such way as to remove the crown of the root, before flowering-if left long after this, the seeds are apt to mature and be scattered by the winds.

t+ Imner scales marmed, appressed. Filaments hairy. * Leaves white-woolly beneath.

\section{C. DISCOLOR.-Spreng. Two-colored Thistle.}

Leaves all pinnatifid, smoothish, and green, above, densely tomentose, and bluish white beneath.

Bi-annual. Stem 2 to 5 feet high, with rather slender, spreading leafy branches, pubescent with crisped, membraneous, hairs; leaves $t$ to 12 inches long, those on the 
branches small; heads ovoid-oblong, 1 to 2 inches in length; florets reddish-purple; anthers whitish.

Hab. Old fields, meadows. Aug. Sept.

Obs. Same as the last.

\section{C. ALtissimUM.-spreng. Tall Thistle.}

Radical leaves pinnatifid, petiolate; stem leaves undivided, lance-oblong, dentate, roughish above; hoarytomentose beneath.

Per-annual? Stem 4 to 8 feet high, branching, and slender above, roughish pubescent; radical leaves 12 to 18 inches long, and 3 to 6 wide, denticulate and ciliate, with spinescent bristles; heads oblong-ovoid, an inch in diameter, with linear-lanceolate spinescent-ciliate bracts, at base; involucral scales of a livid color, near the apex, terminating in a subutate spine; flowers purple, often palish.

Mab. Pastures, thickets. Aug. Sept.

Obs. This, like most other per-amnuals, requires that the roots should be removed or otherwise destroyed. A sharp hoe is the proper exterminator.

** Leaves green on both sides, or lanuginous beneath; pinnatifid.

\section{C. Muticum.- $M_{x}$. Pointless Thistle.}

Stem tall, with slender, paniculate, rather naked branches; heads sub-globose; involucral scales unarmed, closely appressed, viscid and cob-webby.

Per-annuals? Stem 3 to 6 feet high, slender, angular sulcate, and striate-pubescent; branches virgate, fewleaved; leaves 4 to 12 inclies long, segments lanceolate, spinulose; heads half an inch to an inch in diameter; florets purple.

Hab. Swampy grounds. Aug. Sept.

Obs. Requiring care similar with the last.

\section{C. PUMILUM.-Spreng. Dwarf Thistle.}

Stem low, stont; leaves partly clasping, with irregular, undulate, very prickly segments; heads few, large, conspicuously bracteate; outer involucral scales with short spines; florets pale red.

Bi-annual. Plant pale greyish-green; stem 1 to 2 feet high, thick, and sparingly branched, striate, and hairy; leaves 4 to 12 inches long; (the radical ones large) densely hairy on the midrib beneath; heads usually 1 to 3 , rounded-ovoid, 1 to 2 inches in diameter, with large, pinnatifid-spinose bracts at base; florets often 2 inches in length, pale redish-purple, with whitish anthers.

Hab. Old pastures \&ce. July. síug.

Obs. Easy of extermination. Employ the hoe.

\section{C. HORRIDULUM.- $h x$. Yellow Thistle.}

Stem stout; leaves partly clasping, acutely lobed, very spinose with yellowish prickles; heads few, large, with a verticil of pectinately spinose bracts, at base; involucral scales scarcely spinose; florets pale-yellow.

Per-annual? Stem 2 to 3 feet high, mostly simple, striate, lanuginose; leares 4 to 10 inches long; heads often solitary, sometimes as large as in the preceding species; bracts about as long as the involucre; involucral scales tapering to a subulate point.

Hab. Margin of streams. July. Aug.

Obs. This remarkable thistle was first detected in this 
county by the writer, in the Morton meadow, London Grove; and subsequently near the Red-clay creek.

Before leaving the subject I wish to say. 'The species of the thistle which I have doubtingly marked 'perannual' after Darlington, are probably only 'bi-annual' which may have been temporarily changed by local causes.

\section{C. ARVENSE.-Scop). Canada, or Field Thistle.}

Creeping by rhizomas; stem slender, paniculate at summit; leaves sinuate-pinnatifid, ciliate-spinose, undulate; heads numerous, ovoid.

Bi-per-annual. Rhizomas creping horizontally 6 to $S$ inches below the surfice, and sending up erect, bi-annual branches, or aerial stems, which become 18 inches, to 3 feet high; leaves 4 to 10 inches long, slightly decurrent; the radical ones curved, or wary; heads about half an inch in diameter; subpedunculate; involucral scales smoothish, minutely ciliate; florets pale lilac-purple; anthers whitish, fillaments nearly smooth; akenes linearoblong, slightly four cornered; pappus, finally, longer than the florets.

Hab. Fields \&c. Europe. July. Aug.

Obs. The singular bi-prer-annual feature of this species was alluded to moder Achillea millefolium, as being similar.

This unbidden guest, is justly regarder, as one of the vilest pests which has yet invaded our farms. It is therefore incumbent on us to carefully study its nature; and to make oursel ves acquainted with the special laws of its development, whereby it becomes so detrinental: peradventure we may discover its more rulnerable points, and learn the proper mode of attack. We will proceed step by step.

First. We will place this very small seed in the ground. It springs up and grows, like other seeds, and in antumn we have a root with a crown of leaves on its summit; but no stem, or attempt to produce fruit-it is only a seedling plant. The winter kills the foliage, but the root endures, for it is a Bi-annual, or two years plant.

Second. On the return of spring the root sends up a new crown of leaves, larger and more vigorous than the first, and in their midst, a stem, or stems, which grow, and produce leaves, flowers, and fruit after their kind; and after having completed the reproductive process, both root, and stem dies; just as bi-annual plants usually do. 'This presents a simple view which would lead us to the plain, and practical inference; that there is nothing more needed than to cut down this flowering stem, and the trouble would end. Not so. While the flower stem was growing, and maturing its fruit, a secret mischief was plotting at the root, in the form of rhizomas, radiating from the crown, in a horizontal direction. These, many, or few, after travelling far enough, ascend to the surface, and there form rhizomatous plants, very similar in appearance, and capacity for mischief, to our secdling plant of last year; for be it remembered that these rhizomatous plants, have taken the precantion to provide roots for themselves, and therefore, do not die with the parent stem, of which they have now grown quite independent.

Third. Another winter passed, and all those rhizomatous plants put up leares and fruiting stems, just as the seedling plant had done; and having perfected their fruit, die in the same manner. But before doing this, they had each, and all of them, provided rhizomalous plants for 
the ensuing summer. And so the mischief goes on ad infinitum.

Hence, by the aid of the rhizomas, our subject has become a Bi-per-amnual production.

A friend at my elbow suggests, that one who is a close observer, has been more successful in the destruction of the 'Thistle by cutting and digging, the nearer he left the operation to the period of maturation of the fruit; owing; as he supposerl, to the exhausted condition of the roots, by their effort to perfect the seels. The suggestion is worthy of renewed attention. If the foregoing sketch of its development is correct, the parent stem, and its proper root, should naturally perish, without his assistance; but if I am not mistaken, the young rhizomas or root stocks, would not feel the exhaustion of which he speaks; and having an ample supply of their own rootlets, they would not moum over the death of their parent stem, but rather, exult in their own independence.

With this history lefore us-remembering the almost infinite number of seeds which it produces-and knowing that the vitality of the roots is such, that each small fragment, left in the soil, is capable of producing a new plant; * we have the principal data to construct a programme for exterminating Canada Thistle.

I. Never permit a thistle to mature seed. This may be prevented by timely, and judicious cutting.

* This seems to be the common impression. I have not the means to determine whether all the fibrous roots, or only the rhizomes, possess this faculty. The same acknowledgment is due for some of the other rhizomatous plants. In the Linaria vulgaris, however, it is certain that the finest fibrous roots, are extiemely vivacious.
II. Begin operations as soon as the plant has formed a distinct stem. The vitality of the plant is then most active in perfecting the fruit-and is not yet so much directed to the formation of rhizomas.*

If the subjects are few in number-and in this state; I would advise to take a sharp chisel-shaped tool, and cut the stem off obliquely, an inch below the surface; taking care to remove the earth, so as to leave a little cup-shaped cavity, with the fresh divided stem at the bottom. Into this cup immediately drop a small handful of a mixture of three parts of common salt (chloride of sodium) and one part of Copperas (sulphate of Iron), in powder. The hope is, that this would penetrate into, and kill, the parent, before the nascent rhizomes had acquired roots, and an independent vitality of their own-and that they too, would perish - the juices of the parent carrying the poison to its attached and still dependent offspring.

III. As the area widens, still embrace the same opportune season, to remove the parent stems, with their nascent rhizomes, either by the spade, or the plow; always using hand labor when practicable. The principal stocks should always be removed in this way.

The ground should then be thoroughly turned up; stirred and pulverized, by means of the fork-spade, plow, and harrow-taking special care to hand-pick and remove the roots, as they are brought to the surface. Keep the soil well stirred every few days (removing the roots as they may be turned up) throughout the season, so that no

* Renewed observations on some other rhizomatous plants renders it probable that the rhizomes of the Thistle begin to form quite early in the season. They must however, be in a tender, and dependent state, for some time. 
plant shall have the opportunity of forming a leaf, (or lung); and the remaining roots will likely perish.

$I V$. The same care may be requisite the ensuing summer, that all the roots, and seeds, in the soil may be completely eliminated, before laying down to grass.

Lastly. Remember that success depends upon the completeness of the operation.

Other methods may be found available on a small scale especially that proposed for Linaria vulgaris ('Toads-flax), where the means are at hand for smothering it out.

\section{Genus XLI. ONOPORDON.- Faill.}

Heads, and florets, nearly as in Cirsium. Scales of the involucre coriaceous, tipped with a lanceolate, prickly, appendage; receptacle deeply honey-combed; akenes four angled, wrinkled; pappus of numerous bristles, slender, not plumose, united at base, in a horny ring.

Bi-annual? Coarse herbs; stem winged with the decurrent base of the prickly, lobed leares.

\section{C. ACANTHIUM.--limn. Cotton Thistle.}

Stem and leaves cotton.wooly; scales of the involucre linear awl shaped.

Bi-annual? Stem 2 to 4 (even 9) feet high, broadly winged by the decurrent edges of the leaves; leaves ovateoblong, sinuate, and spinous, wooly on both sides, but most so beneath; flowers large, purple, solitary, at the end of the branches; involucre globose, of numerous lanceolate, very pungent, scales, green, with yellowish tips, the upper ones nearly erect, the middle ones spreading, the lower reflexed, all connected by a cottony web; pappus scarce half the length of the florets, jointed, rough clownwards.
Hab. Road sides and fields. Europe. July. Aug.

Obs. Common in New England, and many other places. I introduced a single plant some twelve years ago, and althongh I thought that I had burned every seed it produced, yet one or more plants have appeared every year since (one which I sufrered to grow last year reached the height of 9 feet) showing the danger of introducing specimen plants of a doubtful character. 'To me it seems to be a bi-annual plant_or readily becomes so.

\section{Genus XLII. LAPPA.-Tourn.}

Heads many flowered; florets all similar, and perfect; involucre globose; scales coriaceous, appressed at base, spreading, and abruptly subulate above, with rigid, incurved points; anthers with bristly appendages, or tips, and subulate tails at base; style-branches free, and divergent; akenes oblong, compressed, transversely rugose ; pappus of numerous, short, rough, deciduous bristles; receptacle bristly.

Bi-amnual? Leaves alternate, petiolate, large; heads rather small; florets purple, with bluish anthers.

\section{I MAJOR-Gocrtn. Common Burdock.}

Lower leaves cordate-oblong, upper ones ovate; involucre smoothish, or loosely cobwebby.

Bi-annual. Stem 2 to 4 feet high, paniculately branched, roughish pubescent; leaves green and roughish, above, paler, and cobwebby, beneath; radical ones 1 to 2 feet long, wavy, and erosely dentate, on the margin (sometimes pinnatifid, or deeply, and coarsely, dentate,); petioles 9 to 18 inches in length; stem-leares gradually smaller, more or less, ovate; heads roundish-ovoid, $\frac{1}{2}$ to $\frac{3}{4}$ inch diameter, on short, terminal, and axillary, perluncles. 
Hab. Neglected places. Europe. July. Sept.

Obs. This rough, and troublesome weed, being a brannual, requires but a single digging to extirpate it. A slovenly, and lazy man can hardly hang out a more appropriate shingle, than the Bur-Docks growing about his yard and fences, furnish.

\section{Sub-crder. LIGULAFLORA.}

Florets all ligulate and perfect; disposed in a radiatiform head.

\section{Tribe. CICHORACEA}

Style, branches slender, rather obtuse, uniformly pubescent; stigmatic lines terminating near the middle.

Herbs with a milky juice; leaves alternate, or only radical; receptacle generally naked.

\section{Genus XLIII. TARAXACUM-Haller.}

Heads many-flowered; involucral scales in two seriesthe onter, or lower ones short, the upper long, linear, erect; akenes oblong, ribbed, muricate on the ribs, and at summit, the apex finally produced into a long, filiform beak, which bears, at summit, a copious, white, capillary lappus.

Per-amnuals. Stemless, consequently the leares all radical, pinnatifid, or runcinate; heads large, solitary, on fistular scapes; florets yellow.

\section{T. DENS LEONIS-Desf. Dandelion.}

Leaves lance-oblong, linequally, and acutely, runcinate; involucral scales not corniculate, at apex, the outer ones reflexed; akenes spinellose at summit.
Per-amual. Plant, at first pubescent, at length smooth; leaves 4 to 10 inches long; scapes several from the same root, 4 to 12 inches bigh, (elongating), terete; involucre oblong, the inner scales oppressed; with scarions margins; the outer reflexed, slightly ciliate-finally, the entire involucre reflexed; akenes terminating in a slender beak, which is short, at first, then suddenly elongating about $\frac{1}{4}$ of an inch, and diverging, with the pappus at summit, so as to form a globose head.

Hab. Every where. Europe. April. May.

Obs. I dissent from my friend Dr. Darlington that this is "not a very noxions weed." It is fast becoming so; and is among the most difficult, of the whole catalogue of weeds, to exterminate. When we consider the tenacity of life, which the roots possess-their familiar adaptation to almost every soil, locality, and growing crop-their rapid, and continuous production of manyseeded heads-and the unrivable beauty, and completeness, of the pappus, or parachute, for the dispersion of the seeds; we may well despair of ever being able to effect its extermination. It may be kept in check in tillage lands-but where the plow is not allowed to come, its increase can hardly be prevented.

The most that I can recommend is high firming. That is to pre-occupy the ground by vigorous grass and grain crops and thus smother it out.

\section{Genus. XLIV. SONCHUS.-Linn.}

Heads many-flowered, tumid at base; involucral scales more or less imbricated; akenes compresset, ribbed, not beaked; pappus copious, of very white, soft, fine, silky hairs.

Smoothish, glancous herbs; florets yellow. 


\section{S. OLeraceUs.-Linn. Common Sow Thistle.}

Leares runcinate-pinnatifid, dentate, sagittate, and clasping; akenes transversely rugose.

Annual. Stem 2 to 3 feet high, branched, fistular, tender, glandular pilose above; leaves 3 to 8 inches long, the lower ones runcinate, on petioles 1 to 2 inches in length, upper ones clasping; heals of flowers in terminal, and axillary, cymose panicles; peduncles thickish, clothed, when young, with a loose, flocenlent, white tomentum; involucre tumid, and orbicular, at base, abruptly contracted, above, to an accumination.

Hab. Gardens and lots. Europe. Aug. Sept.

Obs. Though not very detrimental, it is a coarse, unsightly, weed, and always grows in the wrong place. It can be readily eradicated by the scythe or garden hoe.

\section{Order. XVII. PLANTAGINACERE}

Chiefly stemless herbs; leares mostly, all radical, and rosulate, strongly ribbed; flowers spiked, on naked scapes, regular; the parts usually in fours; calyx free from the ovary; corolla membranaceous, and dry; stamens inserted on the corolla-tube, alternate with its lobes; capsule membranaceous, circumcised, two celled; cells one or several seeded; seeds with fleshy albumen.

\section{Genus. XLV. PLANTAGO.-Limn.}

Sepals persistent, slightly connected at base, the margins scarious; corolla tubular, with reflexed lobes, marcescent; stamens four, much excerted; flowers whitish, or ochroleucous, small, bracteate.

t Capsule 6 to 8 seeded.
59. P. MAJOR.LIinn. Common Plantain.

Leaves oval, or ovate, on long, channelled petioles; scape terete, smooth; spike long, cylindric.

Per-anmual. Leares 3 to 8 inches long, 5 to 7 ribbed, with an elastic filament in each rib, generally smoothish (sometimes quite hairy); petiole about as long as the leaf; scapes several, 6 to 18 inches high (including the spike); bracts lanceolate, keeled, appressed, shorter than the calyx; stamens twice the length of the corolla.

Hab. Yards, lots, \&c. Europe. June. Auy.

Obs. Remarkable for accompanying civilization, to every part of the globe. An unbecoming intruder in yards, paths, and too often in cultivated gromuls. The utmost care is needed to prevent it maturing seed.

\section{Order. XVIII. SCROPHULARIACEA}

Chicfly herbs; leaves alternate, opposite, ol verticillate, withont stipules; flowers pentandrous, didynamous, or diandrous; corolla irregularly 5 lobed, subterete, personate, or bilabiate, the lobes imbricated in the bud; stamens inserted on the tube of the corolla; capsule two celled, mostly two valved, and many seeded; placentie united in the axis; embryo small, in copious albumen.

\section{Sub-order. ANTIRRHINIDE五.}

Cpper lip of the corolla outermost, covering the lobes of the lower, in the bud; capsule usually septicidal.

† Corolla subrotate; leaves all alternate. 


\section{Genus XLVI. VERBASCUM.-Linn}

Calyx fire parted; corolla nearly equally five lobed, concave-spreading; stamens five, declined; filaments un. equal, all (or the three upper ones) hairy; capsule ovoid. or globose; seeds rugose-pitted.

Bi-annuals, chiefly. Flowers in dense spikes, or panicu. late racemes.

\section{V. THAPSUS.-Linn. Common Mullein.}

Densely hoary-tomentose; stem stont, simple; leares lance-oral, entire, the cauline ones decurrent; flowers in a thick, dense, terminal spike; two lower filaments smooth.

Bi-annual. Plant pale greyish-green; pubescence much branched; stem 3 to 6 feet high; radical-leaves 6 to 12 inches long, entire, subsessile; stem-!eares smaller; spike 6 to 15 inches long, cylindric, about an inch in diameter; flowers subsessile, bracteate, bright yellow.

Hab. Neglected fields. June. Aug.

Obs. Darlington justly observes, There is no surer evidence of a slovenly, negligent, farmer, than to see his fields overum with Mulleins. As the weed produces a vast number of seeds, it can only be kept in subjection, by a careful eradication while young. This is easily accomplished by hand pulling, before the maturation of the seed.

\section{V. BLATtARIA.-Linn. Moth Mullein.}

Smoothish, and green; stem rather slender, often branched; leaves oblong, serrate, not decurrent; flowers racemose; filaments all hairy.

Bi-annual? Stem 2 to 4 feet high, angular; leaves 2 to 5 inclies long, the lower ones petiolate, often simnatepinnatifid, the upper ones sessile, and clasping; racemes 6 to 18 inches long, leafy, or bracteate, glandular-pubescent; pedicels $\frac{1}{2}$ to 1 inch long; flowers greenish-white, with a tinge of purple-or bright yellow.

Hab. Grass fields. Europe. June. Aug.

Obs. Our Fathers not inappropriately, called this the Bullet Weed. It is an ugly customer, and by reason of the multitude of its seeds, is capable of rapid diffusion. It is quite conspicuous, and easily removed when in flower; but remember-in all the mulleins, one portion of the seed is ripe while another is only embryotic in the flower.

†† Corolla personate, with a spur, or sack, at base; capsule opening by chinks, or valve-like teeth.

\section{Genus XLVII. IINARIA.-Tourn.}

Calyx fire parted; corolla with a prominent palate, closing the throat; upper lip bifid, the lobes folded back; stamens four; didynamous, with a minnte rudiment of a fifth; capsule ovoid, or globose, thin, opening by one or two chinks, and by several teeth, at apex; seeds often margined; leaves mostly alternate; flowers racemose.

\section{L. VULGARIS.-Mill. Toad Flax, Ranstead Weed.}

Smooth and glancous; stem erect, slender, often simple; leaves lance-linear, acute, numerous; racemes terminal, crowded; corolla spurred at base.

Per-annual. Root creeping, subligneous; stem 1 to 3 fect high, terete, leafy, sometimes branched, especially near the summit; usually growing in bunches, or small patches; leaves 1 to 2 inches long; flowers in a bracteate raceme, terminating the stem, and branches; corolla pale 
greenish-yellow-the palate bright orange color; throat villous, spur subulate, about half an inch long; capsule ovoid-oblong; seeds with a dilated, orbicular margin.

Hab. Pastures. Europe. June. Aug.

Obs. Of troublesome plants, the vencrable John Bartram writes, "The most mischievons of these, is the stinking, yellow Linaria. It is the most hurtful plant to our pastures, that can grow in our northern climate. Neither the spade, plough, nor hoe, can eradicate it, when it is spread in a pasture. Every little fibre, that is left, will soon increase prodigiously; nay some people have rolled great heaps of logs upon it, and burnt them to ashes, whereby the earth was burned, half a foot deep; yet it put up again, as fresh as ever, covering the ground so close as not to let any grass grow among it; and the cattle can't abide it."

I do not agree with Dr. Darlington that this is too severely true. I have labored pretty attentively for five years before I fully conquered a little patch in my garden where the ground was carefully cultivated every year. A fibre the size of a cambric thread, and an inch long, wonld come to the surface-and when pulled, would leave other fibres to do the same thing.

It often occurs in patches. These may be smothered out. I had such a patch some twenty-five years ago, about two rods square in a clearing, where the ground had not been ploughed. The weeds eut off a stubble field near by was spread over it to the (lepth of 5 feet, and fifty bushels of magnesian Lime thrown over it. In the autumn of the next year, the cattle tramped, and pulverized the whole mass; which was then spread on the field. I am happy to say that there has not been any return of the Linaria since.

\section{Order XIX. VERBENACFIE.}

Herbs, shrubs and trees. Leaves mostly opposite, without stipules; corolla irregular, often bilabiate; stamens mostly didynamous; ovary free, entire, with the style terminal ; fruit dry (sometimes drupaceous) 1 to 4 eelled, usually splitting into as many one seeded nutlets; seeds with little or no albumen.

\section{Genus XLVIII. VERBENA.-Tinn.}

Calyx tubular, five toothed,-one tooth often shorter; corolla tubular, often curved, salver-form, - the border rather unequally five lobed; stamens included, the upper pair sometimes without anthers; fruit splitting into four nutlets; flowers in terminal, often paniculate, bracteate spikes.

\section{V. HASTATA.-Limn. Blue Vervian.}

Leaves oblong-lanceolate, acuminate, doubly incisedserrate-the lower ones often hastate-lobed; spikes fascicled, or corymbose-paniculate, dense flowered.

Per-anmual. Stem 3 to 5 feet high, roughish-pubescent, mostly purple, with rather short, erect, axillary branches, above; leaves 2 to 5 inches long; petioles $\frac{1}{2}$ to 1 inch in length; spikes 1 to 5 inches long; erect, shorter than the calyx; corolla bluish-purple, pubescent.

Hab. Bottom land. July. Oct.

Obs. In lands not tilled the roots of this weed ought to be carefully removed with the hoe.

\section{V. URTICAgFOLIA.-Limn. Common Vervain}

Leaves lance-ovate, acute, coarsely serrate, spikes loosely paniculate, very slender, elongating; flower's rather distant, small. 
Per-anmual. Stem 2 to 4 feet high, hirsutely pubescent, with slender, axillary, spreading branches above; leaves 2 to 4 inches long, abruptly narrowed at base to a petiole $\frac{1}{2}$ to $\frac{3}{4}$ of an inch long; spikes 2 to 6 inches in length, green, filiform, and rather flaccid; flowers distinct, and finally, a little distant; bracts lanceolate, shorter than the calyx; corolla white, very small, the throat filled with a delicate white villus.

Hab. Pastures, road sides. July. Sept.

Obs. A coarse rough weed. A tidy farmer will not be likely to tolerate it on his premises.

\section{Order XX. LABIATFE.}

Herbs chiefly. Stems square; leaves simple, opposite, or sometimes verticillate, generally aromatic; stipules none; flowers in axillary eymules, or aggregated in terminal spikes; corolla more, or less, bilabiate; anther-cells parallel, or often divaricate-sometimes separated by a long filiform connective; ovary four lobed, becoming, in fruit, four little sced-like nutlets, surrounding the base of the style, in the bottom of the persistent calyx; each lobe, or nutlet containing a single seed, with little, or no albumen.

\section{Tribe. STACHYDER.}

Calyx usually campanulate, five to ten nerved, the orifice regular, or oblique; three to ten toothed, or bilabiate; corolla bilabiate, the upper lip arched, or flat, entire, or emarginate; lower lip variously three lobed; stamens ascending, didynamous, the upper pair shorter; nutlets erect, free at base.

\$ Lamiex: Stamens exserted from the tube of the corolla.

Nutlets truncate at apex.

\section{Genus XLIX. LEONURUS. - Lim.}

Caly $x$ turbinate, five nerved, the border truncate, five toother ; teeth subulate, finally spinose, and spreading; corolla with the upper lip oblong, entire, somewhat arched; lower lip three lobed, the lateral lobes oblong, the middle one entire, or sometimes ob-cordate; anthers approximating in pairs, incumbent; cell; mostly parallel, opening transversely, by little valves, valvelets naked on the margin; nutlets triquetrous, with the angles acute.

Per-anmuals, mostly. Leaves incisely lobed; cymules dense, and closely axillary.

\section{I. CARDIACA.Limn. Mother-wort.}

Lower stem-leares palmate-lobed, upper ones ovate, and cuncate-oblong, mostly trifid; corollit longer than the calyx teeth, the tube with a villous ling, within, at base; upper lip flattish, densely villous above; lower lip spreading, with the midrlle lobe, entire.

Per-annual. Stem 2 to 4 feet high, branched at base, and above, retrorsely pubescent, with a hairy ring at the nodes, often purplish at base; leaves 2 to 4 inches long, rugose, lower, or radical ones, nearly orbicular in outline; petioles 1 to 2 inches long; cymules 3 to 8 flowered, sessile, forming a terminal, interupterl, leafy, spike 6 to 12 inches long; bracts subulate; corolla pale purple.

Hab. Lanes, \&c. Europe. June. Aug.

Obs. Since this weed lost its virtues, as indicated by its common name, it has not been worth its room, and had better be carefully extirpated. 


\section{I. MARRUBIASTRUM.-Linn.}

Stem-leares oblong-ovate, coarsely serrate; corolla shorter than the calyx-teeth, tube naked within; upper lip somewhat arched, the lower rather erect.

Per-annual. Stem 2 to 4 feet high, branched, with retrorse, cinereous pubescence; leaves 2 to 3 inches long, smaller above; radical ones ovate, crenate, long-petiolate; upper floral leaves linceolate, incised-dentate; cymules many-flowered, sub-sessile, forming interrupted, leafy, spikes 6 to 18 inches long; bracts terete, needle-like; corolla whitish, tinged with red.

Hab. Lanes, fields. Europe. July. Sept.

Obs. Nearly related to the preceeding. It was introduced into the Jackson Garden many years ago, and became a common weed of the neighborhood, for miles around: especially down the neighboring stream.

\section{Tribe. AJUGEA}

Corolla with the unper lip sometimes very short, sometimes deeply cleft, with the lobes descending, rarely erect, and arched; lower lip elongated; stamens mostly didynamous and much excerted; nutlets reticulately rugose, obliquely aflixed, and sub-connate at base.

\section{Genus. L. TEUCRIUM.-Linn.}

Calyx tubular, slightly ventricose, nearly equally five toothed, or the upper ones a little broader; corolla with the four upper lobes nearly equal, oblong, and declined, the lower lobe largest, mostly concave; stamens exserted from the fissure on the upper side of the corolla; anther cells confluent; cymules few-flowered, in a terminal rather crowded, greyish-green spilie.
67. T. CANADENSE.-Lim. Wood-sage. Germander.

Greyish-pubescent; leares ovate-lanceolate, acute, serrate, on short petioles.

Per-annual. Stem 1 to 2 feet high, simple or sparingly branched, square with the sides concave, and the angles obtuse, retrorsely pubescent; leaves 3 to 5 inches long; petioles $\frac{1}{4}$ to $\frac{3}{4}$ of an inch; cymules 2 to 3 flowered, in a simple spicate raceme, 2 to 6 inches in length, sometines axillary, and opposite; bracts abont as long as the calyx corolla pale purple.

Hab. Fences, road sides. July. Aug.

Obs. A farmer told Darlington that he had "found it a very troublesome weed, and moreover, exceedingly difficult to eradicate." I have had some experience with this weed; and think that the furmer was right. It spreals rapidly, by means of runners, or stolens, as well as by seeds. If once started it will require car'e, and attention, to get clear of it. It is quite a muisance in some parts of the Toughkenamon valley.

\section{Order. XXI. BORAGINACE石.}

Chiefly hirsute herbs. Stem round; leaves alternate, entire, not aromatic ; stipules none; flowers usually regular, and nearly symmetrical, mostly in one-sided racemes, or spikes, which are revolute, (circinate, or scorpioid), before developement; calyx five parted; corolla fire lobed, with five stamens inserted on the tube; ovary deeply four pated, becoming, in fruit, four seed-like nutlets surroundiug the base of the style; seeds single, pendulous, with little, or no, albumen.

$\S$ Nutlets fixed to the receptacle (free from the style.) † Corolla irregular. 


\section{Genus. II. ECHIUM.-Tourn.}

Corolla sub-companulate, unequally, and obliquely lobed; throat expanded, naked; stamens mostly exserted, unequal; nutlets rugose, or tuberculate, with a small, flat scar at base; flowers in panicled spikes, at first purplish, finally bright violet-blue.

\section{E. VULGARE.-Linn. Viper's Bugloss. Blue Devils.}

Stems tuberculate-hispid; leaves linear-lanceolate; flowers in short lateral spikes.

Bi-anmual? Stem 1 to 3 feet high, branched above; radical leares 5 to 8 inches long, petiolate; stem-leaves smaller, acute, sessile; spikes axillary, numerous ; nutlets sub-ornid, angular on the inner side, keeled on the back, ocuminate, incurved, rough with greyish-brown tubercles.

Hab. Road-sibles, fields. Europe. June. Aug.

Obs. This repulsive stand-off-looking weed, like vice

"Is of such hideous mein,

"That to be hated, needs but to be seen."

Fortunately, the Viper's Bugloss is too conspicuous an object, long to elude observation; and being bi-annual, is easily eradicated, by timely eare, before it sheds its seeds. I have several times found a solitary plant, on our public roads. Be vigilant.

$\S \S$ Nutlets with a small flat scar at base.

\section{Genus. LII. LITHOSPERMUM.-Tourn.}

Corolla funnel-form, or salver-form, with rounded lobes; throat nakel, but mostly with five small, gibbous projections; anthers oblong, sub-sessile, included; styles not exserted; nutlets ovoid, rugose, or smooth ; flowers axillary, crowded at summit, in leafly racemes, or clusters.

† Corolla funnel-form, white; nutlets rugose.

\section{L. ARVENSE.-Limn. Stone-seed. Pigeon-weed.} Gromwell.

Stem hairy; branched from the base; leaves lancelinear, rather acute, nerveless; flowers small, the lower ones rather distant.

Annual. Plant greyish-green, with short appressed hairs; stem 12 to 18 inches high, branched; leaves 1 to 2 nches long, with a midrib, but no lateral nerves, sessile; flowers axillary, sub-sessile; nutlets brown when mature.

Hab. In fields. Europe. May. June.

Obs. Our fathers called this erratic visitor, pigeonweed. It was then much more common than now. And why? They did not then cultivate the grasses, consequently, the soil was left for weeds to grow in. Since the introduction of the grasses as a rotation crop, the stone-seed is seldom seen; or only where the grass is deficient. It was ealled pigeon-weed, from an opinion that it was brought by those birds from some remote region, in their migrations. Good tillage seems adequate to its extermination.

\section{Genus. LIII. CYNOGLOSSUM.-Tommef}

Corolla fumnel-form; lobes rounded; tube equal to the calyx; throat closed by five acute scales; stamens included; nutlets depressed, or convex, more or less covered with short, barbed, or hooked, prickles; flowers mostly in paniculate, or corymbose, naked racemes.

\section{+ Racemes bracteate.}




\section{C. MORISONI.-D. C. Beggars' Lice.}

Stem hairy, leafy, divaricately branched, above; leaves ovate-lanceolate; racemes slender, paniculate, forked.

Annual. Stem 2 to 4 feet high: leaves 3 to 4 inches long, acute at each end, scabrous, the lower ones petiolate, upper one subsessile; racemes pedunculate, 1 to 3 inches long, terminating in slender, divaricate, branches, mostly dichotomous; pedicels about as long as the fruit, corolla bluish white; nutlets convex, densely covered with barbed prickles.

Hab. Thickets fence-rows \&c. July. Oct.

Obs. The slovenly farmer is apt to acquire a practical knowledge of this obnoxious weed; by its bur-like fruit becoming entangled in the manes of his horses, or the wool of his sheep. Being an annual, timely cutting will save this annoyance.

\section{Order. XXII. CONVOLVULACEAE.}

Mostly trailing, or twining herbs, often with a milky juice; leaves alternate, (rarely nome) entire, or lobed, without stipules; flowers regular, often large; ealyx of five imbricated persistent sepals; corolla five plaited, or four to five lobed, twisted, or convolute in the bud; stamens mostly five; capsule one to four celled, often septifragal, few-seeded; seeds with a little mucilaginous albumen; cotyledons sometimes ( $i . e .$, in the leafless plant), wanting.

\section{Sub-order. CONVOLVULER}

Green leafy plants; cotyledons large, foliaceous, crumpled, or corrugated; corolla large, plicate, obscurely lobed.
Genus. IIV. CALYSTEGIA. R. Br.

Calyx covered by two large, opposite, sub-cordate bracts ; corolla campanulate; stamens included ; stigmas two, oblong; ovary imperfectly two-celled; capsule one celled, four seeded.

Per-amual. Leaves entire, sagittate-cordate, at base; flowers solitary, on long, axillary peduncles.

\section{C. SEPIUM. Hedge Bind-weed.}

Stem long, trailing or twining, smoothish ; leaves sagittate, with the lobes obliquely truncate.

Per-annual. Stem 3 to 6 feet long; leaves 2 to 4 inches long, oblong, or sub-triangular; petioles 1 to 3 inches long; peduncles 4 to 8 inches; bracts oblong-cordate, nearly one third the length of the corolla, and almost twice as long as the calyx; corolla about 3 inches long, white, tinged with rose-colour.

Hab. Fields, meadows, \&c. June. Aug.

Obs. Fortunately not common, but daily spreading.

\section{C. PUBESCENS. California, or Mexican Rose.}

Stem trailing, or twining, rough-pubescent, striate; leaves oblong-lanceolate; hastate, the basal lobes widely divaricate, and deeply truncate, pubescent above and beneath.

Per-annuals. Stem 4 to 6 feet long; leaves 3 to 4 inches long, 1 inch wide, the basal lobes 2 or more inches; petioles 1 inch long; peduncles axillary, 2 to 3 inches long; bracts broad-lanceolate, $\frac{3}{4}$ inch in length; calyx shorter than the bracts; petals numerous (double- 
flowered) two to three tines longer than the bracts, pale reddish pink; resembles a rose.

Hab. Gardens and yards. July.

Obs. This plant has been recently introdnced into the flower garden and house-yard, from which it is gradually spreading; and unless diligently watched, may soon become as great a pest as either of its congeneric bindweeds.

\section{Genus. LV. CONVOLVULUS.}

Calyx naked (the bracts being small, and remote from the flower) ; corolla companulate, or fummel-form ; stamens mostly included - stigmas two, rarely three, linear, globular, or capitate.

Chiefly trailing, or climbing, often with milky juice; leaves more or less cordate; peduncles axillary, one-few flowered; flowers usually large.

\section{C. ARVENSIS.-Linn. Field Bind-weed.}

Stem procumbent, or twining; leares ovate-oblong, obtuse, sagittate-cordate; petioles $\frac{1}{2}$ to 1 inch long; peduncles one to three flowered, bibracteate.

Per-annual. Stem 2 feet long, slender, branching, hairy; leaves 1 to $1 \frac{1}{2}$ inches long, sometimes emarginate, a minute cusp teminating the midrib; petioles $\frac{1}{2}$ to 1 inch; peduncles 1 to 3 inches in length, with two small bracts remote from the flower; corolla $\frac{3}{4}$ inch, pale red, or reddish white.

Hab. Cultivated lots. Europe. June. Aug.

Obs. The Flora Londinensis says of this plant.

"I planted twelve feet of a bank in my garden, which was about four feet in beight with some roots of it, early in the spring. 'They quickly covered the whole surface of the bank to the almost total extirpation of every other plant. It being a generally received opinion, that if a plant was cut down close to the ground, it would thereby, be destroyed, or at least, very much weakened; I determined to try the validity of this opinion, by an experiment; and accordingly, the whole of the convolvulus was cut down, somewhat below the surface of the carth. In about a month, the bank was covered with it, thicker than before. I then had recomrse to a second cutting; and afterwards, to a third. But all these were insuflicient; for now (August) the bank is wholly covered with it; nor do I expect to destrey it, but by levelling the bank, and destroying the roots."

"This experiment seems to determine a matter of no small consequence to argriculture viz.: 'That cutting down those plants which have creeping roots, [rhizomes] rather tends to make them spread further, than to destroy them ; and that nothing sliort of actual eradication, will effect the latter." He adds "many fields of corn [probably wheat and barley] are every year destroyed by it; or rendered of little value."

Let the reader fancy to himself, a climbing, twining plant, of such indomitable vitality, and growth, as this and the two preceding Bind-weeds possess; either in his mowing, or grain fields, and he will be able to fully appreciate the conclusion rendered in the above extract-THAT NOTHNG SHORT OF ACTUAL ERADICATION will destroy the roots; and will be prepared to act accordingly. The only plausible method to accomplish this end is, by suffocation. On the small scale, by covering the plants with weeds or rubbish - and on the large scale, by the incessant stirring of the ground, so as to effect the same purpose-always 
being very careful to keep the mischief in the narrowest possible circumscribed limits.

\section{Order XXIII. SOLANACEZE.}

Mostly herbs; with a watery juice; leaves alternate, without stipules; flowers regular, chiefly pentamerous, and pentandrous; on bractless pedicels; corolla plicate, or infolded-valvate, in the bud; stamens inserted into the corolla, as many, and alternate with its lobes; fruit a many-seeded berry, or capsule; seed with fleshy albumen.

* Corolla tubular, or funnel-form; stamens separate.

† Fruit a capsule.

\section{Genus LVI. DATURA.-Linn.}

Calyx tubular, prismatic, separating transversely above the base, in fruit; corolla fumnel-form, border plicate, five toothed; stamens included; stigma two lipped; capsule oval, or sub-globose, mostly prickly, four valved, four celled at base, two celled at summit; seeds reniform, rough dotted.

Annuals. Foetid when bruised; leaves somewhat in opposite pairs; flowers large, solitary, or dichotomal, on short pedicels.

\section{D. STRAMONIUM.-Linn. James-town Weed. Thom} Apple.

Smooth; stem branching dichotomonsly; leaves ovateangulate, or sinuate-dentate, petiolate, capsules muricate, erect.

Annual. Stem 2 to 5 feet high, stout, terete, paleyellowish-green; leaves 4 to 8 inches long; petioles 1 to 4 inches; calyx prominent live angled, nearly half as long as the corolla, deciduous, leaving the persistent base, orbicular; corolla about 3 inches long, ochrolencous; capsule 1 inch in diameter.

In var. Tatu?a. Stem brownish-purple; corolla pale purple.

Hab. Neglected places. July. Sept.

Obs. No agricultural nuisance is easier abated than this.

** Corolla campanulate, or rotate; stamens comnivent; fruit a berry.

+ Anthers opening by terminal pores.

\section{Genus LVII. SOLANUM. - Limn.}

Calyx mostly five parted, spreading, persistent; corolla rotate; border picate, usually five lobed; stamens exserted, often slightly cohering; being mostly two celled; leaves various; flowers mostly in pedunculate, cymose clusters.

\section{$\S$ Stem and leaves unarmed.}

\section{S. NIGRUM.-Linn. Common Night-shade}

Leaves ovate, obscurely repand-dentate; flowers in lateral, umbel-like cymes; fruit globose, small, black.

Annual. Stem 1 to 2 feet high, much branched, angular, or slightly winged; leaves 2 to 3 inches long; petioles 1 inch; cymes few-flowered, extra-axillary, nodding; corolla white, small ; berries $\frac{1}{4}$ inch in diameter.

Hab. About yards, \&c. Europe. July. Sept.

Obs. This weed has nothing to recommend it-but is highly objectionable, on account of its poisonous berries, so tempting to children. By all means cradicate it. 
76. S. DULCAMARA.-Linn. Bitter-sweet.

Somewhat shrubby, and climbing; leaves cordate-ovate, the upper ones often hastate, or a uriculate-lobed, at base; flowers in lateral cymes; fruit, oval, small, red.

Per-annual. Stem 6 to 8 feet long, flexuous, smoothish; leaves 2 to 4 inches long; petioles $\frac{1}{2}$ to 1 inch; cymes opposite the leaves, nodding; pedicels short, clavate; common penducle 2 inches long; corolla violet-purple, the lobes spreading, or reflected, each with two green dots, or tubercles, at base; berry near $\frac{1}{2}$ an inch long.

Hab. About houses. Europe. July. Sept.

Obs. The same objections lie against this, as the last -on account of its poisonous fruit, without any rerleeming qualities-except it be, that our good mothers more than half a century ago, used to cut the half-succulent stems into short pieces, string them on threads, and apply them round their children's necks, as beads. 'They did probably prevent excoriations of the necks of fat children, like any other beads-but those good women evidently looked beyond this, to some talismanic influence which the plant was capable of exerting-whether to keep the worms doun - to cure the belly-ache-or like the blue woollen string, to prevent bleeding at the nose; your deponent sayeth not.

$\S \S$ Stem, and leaves, more or less prickly.

77. S. CAROLINENSE-Linn. Horse Nettle.

Stem suffruticose, branching; leaves ovate-oblong; acute, sinuate-angled, and often subhastate, prickly on both sides; flowers in loose, simple, lateral racemes; fruit globose, small, orange-yellow.
Per-annual. Stem 1 to 2 feet high, anmual, but firm and almost shrubby, armed with sharp spreading prickles; leaves 4 to 6 inches long, stellately hirsute; petioles $\frac{1}{2}$ to $1 \frac{1}{2}$ inches long; racemes opposite to, and often longer than the leaves; pedicels about half an inch; corolla purple, or bluish-white; berries $\frac{1}{2}$ inch diameter.

Hab. In fields. July. Oct.

Obs. The farmer can hardly have a more unpromising nuisance to contend with than this. I can not do better than refer the reader to the Obs. under Cirsium arvense (p. 54) for general treatment. Where it only exists in small well circumscribed patches, I would advise smothering it out, as mentioned under Linaria vulgaris (p. 65.)

The owner of land which has become foul with such a terrible pest, who will quietly fold his a:ms, and supinely look on, while it extends from acre to acre, of his own, and his neighbour's premises-and there are many such-is a fir worse, and more difficult nuisance than the weed itself. A nuisance which can only be abated by removing him from the management of the land; and letting it to one who will faithfully perform his duty, and remunerate himself out of the products of the soil.

A law requiring this, would be no more arbitrary, nor unjust; and is as much needed, for the health of our Agriculture; as the quarantine laws are, for the physical health of our cities. (See p. xviii.)

\section{Order XXIV. APOCYNACEA.}

Plants with a milky juice; leaves entire, mostly opposite, without stipules; flowers regular, pentamerous, and pentandrous; corolla-lobes convolute, and twisted, in the bud; stamens alternate with the lobes; filaments mostly $4^{*}$ 
distinct; pollen granular; fruit usually a follicle, with the seeds comose; sparingly albuminous.

\section{Genus LVIII. APOCYNUM.}

Calyx five parted; corolla eampanulate, fire lobed, with five triangular appendages in the throat, opposite the lobes; stamens inserted at the base of the corolla, short; anthers sagittate, connivent, slightly adherent to the stigmas; ovaries two, oblong, surrounded at the base by five glands; follicles in pairs, rigid, long and slender; seeds imbricated, linear, with a silky tuft (coma) at apex.

Per-amnual. Herbs; flowers in axillary, or terminal, paniculate cymes.

\section{A. ANDROSFMIFOLIUM.-Limn. Dog's-bane.}

Leaves ovate, rounded at base; cymes few-flowered; corolla-tube longer than the calyx-the lobes recurved.

Per-annual. Stem 2 to 3 feet high, smooth, purple, erect, with spreading branches; leaves 2 to 3 inches long, acute, mucronate; petioles $\frac{1}{4}$ inch; eymes mostly terminal; pedicels with subulate bracts at base; calyx-segments lance-ovate, about half as long as the corolla-tube; corolla pale red, or whitish, with purple stripes; ovaries distinct; stigmas united, large; follicles about 4 inches long, terete, attenuated at apex; seeds $\frac{1}{4}$ inch long, very narrow, truncate at apex.

Hab. In fields, \&c. June. Sept.

Obs. The erratic roots of this weed, are very tenacious of life, and from their habit, rather difficult to extract from the soil. A small patch has, for several years resisted the plow, the scythe, and frequent hand-pulling. The next expedient will be the Grubbing Hoe.
79. A. CANNABINUM.-Linn. Indian Hemp.

Leaves lance-oblong, acute at each end; cymes manyflowered; corollo-tube equal to the calyx, lobes erect.

Per-annual. Stem 2 to 4 feet high, smooth, purpiish, a little glancous, with rather ereet branches; leaves 2 to 5 inches long, ovate-lanceolate, to lincar-oblong, acute, or conspicuously mucronate; petioles $\frac{1}{4}$ to $\frac{1}{2}$ an inch : cymes somewhat paniculate, one frequently dichotomal, near the summit; pedicels with lanee-linear bracts at base; calyx segments lanceolate, about as lono as the corolla-tube; corolla mostly greenish-white, sometimes tinged with red; follicles, as in the preceeding, but more slender.

Hab. Borders of woods. Aug. Sept.

Obs. Less common than the last. Habits similar.

\section{Order. XXV. ASCLEPIADACERE.}

Per-amnual. Herbs with a milky juice; leaves entire, usually opposite, sometimes, verticiliate, or scattered; stipules none; flowers regular, pentamerous, and pentandrous; corolla-lobes mostly valvate in the bud; filaments mostly dilated, and connate in a tube, including the pistils-the tube augmented by a crown of five lobes, or scales, at summit; anthers erect, mited in a pyramidal, five angled mass, truncate at apex, each two celled, cells opening perpendicularly, or transversely; pollen in waxy masses, which are attached in pairs, to five small processes at the angles of the stigma; ovaries two; styles distinct, co-allesced at summit, forming a five angled stigma, common to both; fruit a follicle; seeds imbricated, compressed, mostly margined, and comose; albumen thin. 


\section{Genus. LIX. ASCLEPIAS. - timn.}

Calyx deeply five parted, persistent, segments lanceolate spreading; corolla five parted, reflexed, deciduous; crown of five headed lobes, each containing a subulate, ineurved process; anthers adherent to the stigma, tipped with membranaceous appendages, the cells opening perpendicularly, with rigid, projecting, wing-like margins; each cell containing a flattened, pyriform, waxy, pollen mass; the two contiguous pollen masses of adjacent anthers forming pairs, which hang by their slender summits, from five small, biack, shining, cloven, tubercles, or glands at the angles of the stigmas; ovaries in pairs, one of them usually abortive; follicles rather ventricose, acuminate, soft; seeds numerous, each with a tuft of silky hairs at the hilum; flowers in simple, pedunculate umbels, terminal, and lateril.

\section{A. PEYTOLACCOIDES-Pursh. Poke-leaved Asclepias.}

Leaves ovate, or ovate-lanceolate, acuminate; umbels mostly lateral, long-pedicelled, and loose.

Per-annual. Stem 3 to 5 feet high, rather slender, somewlat pubescent in lines; lcaves 6 to 9 inclies long, acute at each end; petioles $\frac{1}{2}$ an inch; umbels lateral and terminal; common peduncles 2 to 3 inches; pedicels 1 to

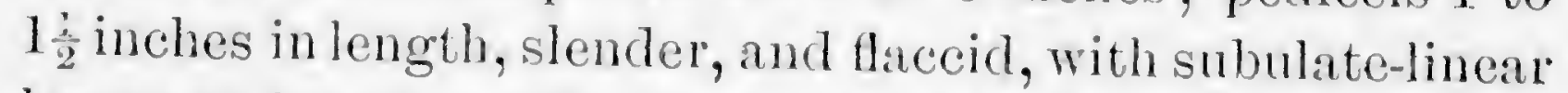
bracts at base; corolla greenish-white; crown with tinges of purple, at base; follicles 4 to 6 inches long, minutely pubeseent.

Hab. Fields, \&c. June. Sept.

Obs. I have found this large, showy plant quite obstinate in yielding to ordinary means of extermination. Its runners gives it a wide range, and require more than ordinary care, to fully eliminate them from the soil.

\section{A. INCARNATA.-Linn. ミwamp Milk-weed.}

Leaves oblong-lanceolate, acute, obtuse at base, petiolate; umbels numerous, terminal, and sub-terminal.

Per-annual. Stem 2 to 4 feet high, with somewhat corymbose branches, smoothish with pubescent lines; or sometimes coarsely tomentose-pubescent; leaves 3 to 6 inches long, often almost truncate at base; petioles $\frac{1}{4}$ to $\frac{1}{2}$ inch; umbels rather small; common peduncles 1 to 2 inches long, often densely pubescent; pedieels $\frac{1}{2}$ to $\frac{3}{4}$ inch long, with lance linear, carducons, bracts, at base; corolla reddish purple, crown paler; follicles about 3 inches long, pubescent.

Hab. Moist meadows. July. Sept.

Obs. This coarse, and homely plant is a useless incumbrance in low pastures, occupying a good deal of space, to the exclusion of the grasses. It ought to be ejected by the proprietor. It can be readily eradicated by the proper use of the grubber, where the plow, and after tillage may not come.

\section{DIVISION. III. Apetalous Exogenous Plants}

Corolla usually none; the floral envelopes being, mostly, in a single series (calyx) - or sometimes wanting altogether.

\section{Order. XXVI. PHYTOLACCACEA}

He rbs, or suffruticose plants; leaves alternate, entire, without stipules; flowers racemose; calyx of 4 to 5 petallike slightly connected sepals; stamens as many, or twice 
as many, as the sepals; ovary mostly composed of ten verticillate, confluent, one ovuled carpels; with the styles, or stigmas distinct; fruit baccate, or dry; embryo forming a ring round mealy albumen.

\section{Genus. IX. PHYTOLACCA.T'Tournef.}

Elowers mostly perfect; sepals five roundish-ovate; persistent; stamens ten; anthers incumbent; fruit a depressed-globose, compound, five to ten celled berry.

Per-annual. Leaves petiolate, large; flowers in lateral racemes.

\section{P. DECANDRA.-Linn. Common Poke.}

Stout, smooth, often purple; leaves ovate-oblong; berries ten celled, juicy, dark-purple.

Per-annual. Stem 4 to 8 feet high, branching, terete, or obtusely ridged; leaves 5 to 10 inches long, thin, acute, or acuminate; petioles, 1 to 2 inches; racenes opposite the leares, 3 to 6 inches long, simple ; pedicels $\frac{1}{2}$ an inch, with a subulate bract at base; usually two smaller, subopposite ones near the midnle; sepals white.

Hab. Fence corners, de. June. Aug.

Obs. 'The seeds of this coarse weed, are annually carried by the birds, and dropped over our farms; but its destruction is always an easy task. 'Those who prefer Pole to Asparagus had better plant a bed of it in some sechuded corner. This would be more economical, for the farmer, and convenient for the cook, than to cultivate it as a field-crop. It would then be quite easy to prevent the seed from being ripened, and carried over the farm.

\section{Order. XXVII. CHENOPODIACEA}

Chicfly coarse herbs; leaves alternate, rather flesly; stipules none; flowers inconspicuous, bractless; sometimes dioicous, or polygamous; calyx free fiom the ovary, two to five lobed, imbricate in the bud, persistent, embracing the fruit; staniens usually as many as the calyx lobes, and opposite to them ; orary one celled, becoming a one seeded utricle, or akene, in fruís; embryo peripherical, coiled round the farinaceous albumen.

\section{Genus. LXI. CHENOPODIUM.-Linn.}

Calyx fire parted, lobes often keeled; ovary depressed; styles two, very short; utricle membranaceous, included in the five angled calyx; seed horizontal, lenticular, margin rather acute; embryo forming a complete ring round the albumen. Plant smooth, glaucous-mealy; flowers greenish, sessile, in spiked racemose, or panicled clusters.

\section{C. AIBUM.-Linn. Lambs'-quarters. ?}

Leaves glancous beneath, rhomboid-ovate, sinuate-dentate, cuneate, and entire, at base; racemes compact, pulverulent, somewhat leafy.

Anmual. Stem 3 to 6 feet high, angular, branched, often striped with green and yellow, or purplish; leaves 1 to 3 inches long; petioles 1 to 3 inches; flowers in clusters; calyx depressed, five angled, by the keels of the incurved lobes; seed dark purple, smooth, shining, lensshaped, with a small notch on one side.

Hab. In garden lots. Europe. July. Oct.

Obs. A rank, troublesome weed in cultivated grounds; requiring much care to prevent it seeding the soil for another crop. 


\section{Order. XXVIII. AMARANTHACE}

Herbs; characters nearly as those of the preceding order; but the flowers are imbricated, with dry, scarious, persistent, and usually colored, bracts ; stamens as many as the sepals, and opposite them; fruit a utricle, one to several seeded, bursting irregularly; seeds lenticular-reniform, often vertical; embryo curved round farinaceous albumen.

\section{Genus. LXIT. AMARANTHUS.-Lim.}

Monoicously polygamous; calyx of three or five sepals, mostly colored, and slightly connected at hase; stigmas two or three; ntricle circumcised, or indehiscent, one seeded; embryo forming a half circle round the albumen.

Annuals; flowers minute, in axillary, or terminal, spiked cluster's.

\section{A. HYBRIDUS-Linn. Pig-wead}

Roughish pubescent, sparingly branched; dull green ; leaves lance-ovate; flowers green, pentandrous, clustered in dense: compound, ovoid-oblong spikes.

Annual. Stem 2105 feet high; leaves 2 to 5 inches long, tapering to the apex, point rather obtuse, setaceously mucronate; the base abruptly narrowed to a petiole 1 to 3 inches long; flowers sometimes purplish_the staminate and pistillate intermised.

Hab. Cultivated lots. Aur. Oct.

Obs. A troublesome weed, like the preceding, and requiring the same respectful attention.
85. A. SPINOSUS.-Linn. Thorny Amaranthus.

Smoothish, bushy-branched, often purplish; leaves rhomboid-lanceolate; axils spinose; flowers pentandrous, clustered, in compound, oblong-terete spikes.

Annual. Stem 1 to 3 feet high; leaves 1 to 2 inches long, rather obtuse, mucronate, rough-dotted, with olaucous blotches beneath; petioles as long as the leaves, with two subulate spines at base, $\frac{1}{4}$ to $\frac{1}{2}$ inch long.

Hab. Waste grounds. India. Aur. Oct.

Obs. This is another vile pest, which commerce has brought to our sea-ports, whence it is rapidly spreading over the comntry. My specimens were gathered in Wilmington, Del, where it is abundant. Eally and continued vigilance, alone, can prevent its spread, when once it has gained a foot-hold. The neglect of this, must end in a long, and arduous, struggle for its extermination.

\section{Order XXIX. POLYGONACEF}

Herbs, with nodlose stems; leaves altemate, usually entire, with stipules, sheathing the stem, above the leaves; flowers generally perfect; calyx of three, or six sepals, connected at base, and persistent; stamens four to twelve, inserted on the base of the calyx; ovary one celled f fruit akene-like-lenticular, when there are two styles-briquetious, when there are three; embryo curred, or straightish; albumen mealy.

\section{Genus LXIII. POLYGONUM.-Lim.}

Calyx mostly five parted, often colored, cmbracing the fruit; stamens mostly eight, arranged singly; or in pairs, opposite the calyx-lobes; styles two to thrce, consequently 
the akene either lenticular, or triquetreus; embryo in a groove of the albumen, and curved half way round it; flowers fasciculate, often with sheathing bracts; pedicels articulated.

§ Stems climbing, or twining.

† Stems retrorsely aculiate.

* Styles two; akenes lenticular.

\section{P. ARIFOLIUM.-Linn. Halbert-leaved Tear-thumb.}

Leaves hastate, acuminate, on long petioles; cluster's racemose, few-flowered; peduncles glandular-hispid ; stamens 6 .

Annual. Stem 3 to 6 feet long, rather coarse, branching, sulcate-angled, often purplish; leaves 2 to 5 inches long; petioles $\frac{1}{2}$ to 3 inches; stipules ovate, clasping; ciliate; flowers purple, with paler edges; calyx mostly four parted; bracts hirsute.

Hab. Ditches, and swamps. Aug. Sept.

Obs. With proper drainage, and judicious management of bottom lands this rough weed will disappear.

The same remark will apply to other plants of this, and many other Genera which find the pabulum of their existence in the crude, neglected condition of meadow grounds. In most cases, these would aftord a more generous remuneration for the labor of improvement, than almost any other portion of the farm; by increasing both the quantity, and the quality of their products. 'They would then cease to be-as they too frequently are-a source of noxious seeds, to foul the other portion of the farm. Farmers would be wise to consider this.
Genus LXIV. RUMEX.-Lim.

Flowers sometimes dioicous; calyx of six sepals, three inner ones larger, valvately connivent, often bearing a grain-like tubercle on the back; stamens six, in pairs, opposite the outer sepals; styles three, stigmas penciltufted; akenes triquetrous, free, not winged; embryo slightly curved, lying along, one side of the albumen.

Per-annuals. Petioles somewhat sheathing at base; flowers mostly green, verticillate in paniculate racemes.

* Inner sepals entire; all three graniferous.

\section{R. CRISPUS.-Linn. Sour Dock. Curled Dock}

Radical leaves lance-oblong, rather acute, wavy, or curled, on the margin; verticils crowded.

Per-annual. Stem 2 to 4 feet high, sulcate-angled, smoothish, somewhat paniculately branched, above; radical leaves 8 to 15 inches long; and 1 to 3 wide; petioles 2 to 4 inches in length; stem leaves smaller, linear-lanceolate; flowers in crowded, verticillate fascicles, with scarious involucres at base; inner sepals much larger than the onter ones, entire, or obsoletely denticulate, near the base; each with an ovoid, acuminate, excrescence, on the back.

Hab. Fields and lots. Europe. May. July.

Obs. 'The Docks are among' the inost common evidences of a slovenly farmer. This species, having a straight spindle-shaped root, is easily drawn out by the hand, when the ground is wet-and this is the most speedy, and effective method of doing the work; always taking care to anticipate the ripening and shedding of the seed. Remember also, that dock-roots are retentive of life, when out of the ground, and are thus enabled to mature the seed, after 
being pulled. To guard against this ; keep the Brushheap at hand, and place the docks $i n$ it as fast as gathered. Permit no new seed to enter the soil-and that which is already there, will soon become exhausted, and cease to cause trouble.

\section{R. OBTUSIFOLIUS.-Limn. Bitter Dock}

Radical leaves sub-cordate-oblong, obtuse, cienulate; verticils loose, and rather distant.

Per-annual. Stem 2 to 4 feet high, sulcate-angled, roughish, paniculately branched; radical leaves 8 to 12 inches long, and 3 to 6 wide; petioles 3 to 6 inches long; flowers in interrupted, verticillate fascicles; inner sepals with long, acute teeth, near the base, and one of them bearing a large grain on the back.

Hab. Fields and lots. Europe. June. Aug.

Oos. The foregoing observation applies equally to this species, except, that it is a much coarser plant, whose larger, and branched roots require the aid of the Dock-spit to wrench them from the earth. The after care need not be repeated.

\section{Orāer XXX. EUPHORBIACE忸.}

Plants usually with an acrid, milky juice; leaves mostly simple; stipules small, and deciduous, or wanting; flowers commonly monoicous; calyx valvate in the bud; sometimes wanting; stamens definite, or indefinite; fruit capsular, lobed, or compounded of two or three, or many carpels, united; seed suspended, mostly caruncled; embryo in fleshy albumen.

\section{Genera LXV. EUPHORBIA.-Linn.}

Flowers included in a cup-shaped, four to five lobed, involucre, resembling a calyx, or corolla, with glands at its sinuses; staminate flowers numerous, lining the base of the involucre, each from the axil of a little bract, and consisting of a single stamen, jointed on a pedicel ; anther cells globular, separate; pistillate flowers solitary, in the middle of the involucre, consisting of a naked, three lobed, three celled, pedicellate ovary; styles three, bifid; capsule separating into three carpels, which severally split, elastically, into two valves; carpels one seeded; peduncles ofcen umbeliate clustered.

\section{E. HYPERICIFOLIA.-Limn. Field Euphorbia.}

Stem oblique, or leaning, with divergent branches, smoothish; leaves obliquely oblong, or sub-filcate, serrate; fruit smooth; seeds blackish.

Annual. Stem 9 to 18 inches high, slender; branches somewhat dichotomous, mostly pubescent on one side; leaves $\frac{1}{2}$ to $1 \frac{1}{4}$ inches long, linear-dotted, often blotcher along the midrib; petioles one line long; stipules scalelike; involucre axillary, and dichotomal, pedicellate, forming small corymbose clusters at the extremities of the branches; glands on small, roundish, subsessile, petal-like appendages, which are white, or purple edged with white.

Hab. 'Thin grass fields. July. Sept.

Obs. This is often a troublesome weed in corn fields and cultivated lots, where the hand, and horse-hoes, with sufficient muscle, are its most destructive enemies. It often abounds in pastures, with a thin growth of grass; where it has been accusel of causing the salivation or 
slobbering of horses. The acrid qualities of the Euphorbias, might readily be supposed to produce an effect similar to that of tobacco on another animal of note; but the horse being the wiser of the two, will not knowingly eat of either plant; and therefore does not voluntarily, and intelligently render himself fitthy and disgusting to his associates. It is yet a controverted question, but $I$ am satisfied that the salivation is cansed by the clover itself, more frequently than by any other food. Whether the noxious quality inheres in the plant, or is only deposited on its surface, I will not venture to determine. It seems most probable that the poison is extrinsic to the clover, and dependent on certain meleoric conditions of the atmosphere. The immediate cause may be either insectiferous, or fungoid. It is yet undetermined.

\section{CLASS II. Endogenous or Monocotyledonous Plants.}

Stems not distinguishable into bark, wood and pitch; leaves mostly parallel-lined, alternate, and entive; embryo with a single cotyledon.

\section{Order XXXI. ARACEAE.}

Mostly herbaceous, stemless, with acrid, or pungent juice; leaves radical, sometimes dissected; petioles sheathing at base; flower's dioicous, monoicous, or all perfect, crowder on a spadix, which is frequently sulrounded by a spathe; sepals four to six or none; petals none; fruit usually a berry; seeds with fleshy albumen, or sometimes, a large fleshy embryo without albumen.

\$ Spadix surrounded by a spath.

† Flowers perfect; sepals 4 ; ovaries coalescing.

\section{Genus LXVI. SYMPLOCARPUS.-Salisy.}

Spathe conch-shaped, acuminate; spadix on a short peduncle-like scape, oval, densely covered, and tessellated, with flowers; stamens four, opposite the fleshy, cucullate sepals; ovary one celled; stile four sided, tapering to a minute stigma; fruit an oval, fleshy, berry-like mass, coalesced with the base of the persistent sepals, and imbedded in the spongy receptacle; seed globular, without albumen.

Per-annual, stemless herbs, with a strong, blended odor of skunk, and garlic; rhizoma thick; leaves radical, enlarging; spathe sub-sessile, preceding the leaves, spotted with purple-brown, and yellow.

\section{S. FOETIDUS.-Salisb. Swamp Cabbage. Skunk-weed.}

Leaves, at first, orbicular-cordate, finally cordate-oral, on short petioles; spadix much shorter than the spathe.

Per-annual. Root in verticils of fleshy fibres, from a thick, truncate lhizoma ; revial stem none; leaves appearing after the spadix has flowered; orbicular-cordate, at length cordate-oval, very large, entire, smooth; stipules expanding, ovate-oblong, acuminate, often spatulate; spathe sub-sessile spotted with purplish-brown, green, and yellow; spadix an inch in diameter, on a short, thick, peduncle; flower's compact, appearing tessellated, sepals dark-brown, fleshy; style projecting above the sepals; fruit fleshy, coalesced with the base of the persistent sepals; and imbedded in the surface of the receptacle; seeds globose, size of a garden pea.

Hab. Wet grounds. March. Sept.

Obs. This is unsightly, and occupies much room; for 
which its early bloom can hardly compensate. The strong roots require the grubber for their removal.

\section{Order XXXII. LILIACEAE.}

Roots often bulb-bearing; leaves sessile, or sheathing, flowers perfect, regular; the perianth mostly with six (rarely four) lobes, or petal-like parts, free from the ovary; stamens as many as the lobes of the perianth; anthers introrse, erect, or incumbent; styles united; stigmas three, sometimes united; fruit a three celled loculicidal capsule, or sometimes, a berry; seeds few, or several; embryo in fleshy allumen.

\section{Tribe. ASPHODELEA}

Roots fascicled, or bulb-bearing; perianth-lobes more or less united below; fruit a three celled, loculicidal capsule; mostly few seeded.

† Bulb-bearing; perianth lobes slightly united.

\section{Genus LXVII. ORNITHOGALUM. -Toun.}

Perianth-lobes almost distinct, partly colored (white) spreading, several-nerved; filaments dilated, subulate; style triquetrous; stigma obtuse ; capsule membranaceous, obtusely trigonous; seeds few, sub-globose.

Per-amnuals. Bulbs coated; leaves linear, channelled; flower's racemose, or corymbose, on a naked scape.

\section{O. UMBELLATUM.-Lim. Ten-o'clock.}

Racemes corymbose; peduncles longer than the bracts; perianth-lobes white within, green outside, with white margins; fillaments simple.
Bi-per-annual. Bulbs bi-annual. Bulbs small, white; leaves 6 to 12 inches long, numerous, very smooth; seape 6 to 9 inches high, terete; peduncles 1 to 2 inches long, alternate, and rather corymbose, than umbellate, each with a skinny, acuminate bract, at base.

Hab. Pastures, lots, \&c. Europe. May. July.

Obs. 'This seems an appropriate place for some general observations on bulb-producing weeds; Ten o'clock, Bluebottles and Garlic. Especially, as the same remarks will apply equally to the present plant, and the one following.

It should be known to every one, that bulbs possess, in a large degree, and are very retentive of, vitality; and consequently, will bear a great amount of sun, and exposure, before they lose the faculty of rejurenation. It should also be known, that there is a cluster of young bulblets formed around the parent bulb, every year, which are easily parted from it, and in turn, become the parent bulb of the next year. If the ground is left undisturbed, a cluster of bulbs will be produce?, increasing in number from year to year, until it will count hundreds, or thousands. But where the ground is frequently tilled, the chusters will be broken up, and scattered, where each detached bulb will commence to form a new chister; or colony, ready to be dispersed by the next course of tillage. 'Thus, instead of a single cluster, there may be a hundred, and they, widely scattered. It must, therefore, be obvious, that ordinary tillage is not the remedy for bulb-producing weeds. Some particular mode of tillage may, howerer, be found serviceable.

Some forty-three years ago I came in possession of a field that was completely stocked with this perplexing weed. It had been in corn, the previous year. When plowed, and put down to oats, the surface was literally 
covered with the young stems and bulbs of the Ten o'clock; and when bleached by the sun, they were conspicuous as far as the field could be seen. Fortunately, a change of inclosures, made it convenient to put the same ground in oats, another year. I was the more willing to do this, for reasons which will be rendered, in the next article. Suffice it to say, that, after this course, the ten o'clocks disappeared, and have not been troublesome since. It may be diffieult to account for the change; but I can hardly entertain a doubt, that the-TwIE IN OATSwas the cause of their sudden exit. Let others try the experiment, and report the result. (See the next article.)

\section{Genus LXVIII. ALLIUM.-Linr.}

Perianth-lobes entirely colored, one nerved, becoming dry, more or less persistent; filaments subulate, dilated below, the inner, or alternate ones, sometimes, with a slender cusp, or short tooth on each side; style filiform ; stigma simple, or trifid; capsule membranaceous, trigonous, or somewhat three lobed; seeds few, roundish, black, rough-rlotted.

Per-annuals, bulbs bi-amnual. Strong-scented; scape, and leaves, from a coated bulb; leaves flat, or terete, and fistular, distichously arranged; flowers in a dense, terminal, umbel, or head (sometimes the flowers changing to bulblets) embraced by a membranaceous, one or twovalved spathe.

$\S$ Umbels often densely bulb-bearing; with or without flowers.

$\uparrow$ Leaves terete, and fistular.

\section{A. VINEALE - Linn. Fleld Garlic.}

Scape slender, sub-cylindrical, sparingly leafy, to the midlle; leaves cylindrical, with a narrow channel on the upper sille; spathe one valved, acuminate.

Bi-per-annual. Bulbs small; scape 2 to 3 feet high; leaves 8 to 15 inches long; umbels globose, an inch in diameter (smaller and densely capitate, when bearing bulblets, these often vegetating while in the head); perianth deep purple, tinged with green.

Hab. Fields. Europe. June. Aug.

Obs. 'Two qualities possessed by this foreigner renders it more cbnoxious than the other bulb-bearing weeds under notice.

1. The plant when eaten by cows, renders their milk, and butter, unfit for the table.

2. 'The bulblets which replace the flowers, when mingled with wheat, makes the manufacture of flour difficult, and renders it unfit for good bread.

Garlicky milk, butter, or bread is quite unpalatable.

It therefore becomes an object of considerable importance to be able to eradicate so distasteful a weed from the pasture, and grain producing lards. We said in the last article how ordinary tillage, only made the matter worse. While a method of special tillage was apparently quite successful. For the origin of that method, reference was made to this article.

'Towards the conclusion of the last century, my Father possessed a field, remote from the homestead, which had, for a long time, lain a neglected common. It was overgrown with Briers-Mulleins-St. John's Wort-and Garlic. In process of time the three former were measurably subdued-but the latter continued to hold undisputed posses- 
sion. It afforled armirable, early sheep pasture--hardly any thing more.

No doubt, High Farming, may be made available to smother up, and crowd out many noxious weeds; even garlic itself, to a certain extent-but in that day the application of Lime and Plaster was little known-and the farrago of modern fertilizers, had not yet come to the birth-hence, High. Farming was then, an impracticability. For some years the condition of the field remained statu quo.

At length, for some reason not now known, the field was put down to oats, two successive years; and, as occured with the Ten o'clocks, the Garlic was almost entirely killed out; and has never been a serious annoyance since. About the same time, or soon after, the application of lime commencel, with the cultivation of better grasses, \&c. But it is worthy of remark, that while the grass crop may be a check to the Garlic; the conditions of the wheat crop, are highly favorable to its development. High tillage with the grasses will do much.

\section{Order. XXXIII. CXPERACF正.}

Herbs, grass like, often caspitose; rhizomes fihrous, creeping, often tuberiferous; culm solid, with pith, subnodose, often angular; leaves distichously alternate, sessile, grass-like; petioles dilated, and forming an entire sheath; blade sometimes wanting; flowers perfect, or monoicons (rarely dioicous) in little bracteate clusters, or spikelets; usually one flower, in the axil of each of the glume-like, imbricated bracts, or scales; perianth (perigynium) none; stamens usually three; ovary one celled, with a single erect ovule; in fruit becoming an akene (or coryopsis) which is lenticular, or triquetrous, as the style is bifid, or trifid; embryo minute, inclosed in the base of copious, farinaceous, albumen.

\section{Tribe. CYPERE $\not$ E}

Flowers perfect; spikelets usually many-flowered, with the bracts distichously imbricated; perigynimm mostly none; sometimes consisting of retrorsely hispid bristles; styles rarely bulbous at base.

\section{Genus. LXIX. CYPERUS.-Linn.}

Spikelets usually compressed; variously aggregated and arranged. Scales often decurrent at base; perigynium wanting; stamens sometimes two, or one.

Per-annual? Culms cespitose, triquetrous, leafy at base, and with an unequal, foliaceous, involucre at summit; peduncles unequal, sheathed at base.

$\S$ Spikelets compressed, linear, or lance-oblong, many flowered.

† Stamens three; style trifid.

\section{C. STRIGOSUS.-Lim. Bristly Galingale.}

Spikelets subulate-linear, spreading all around in loose, oblong, pedunculate spikes; sheaths of the peduncles bifid, two bristled; involucre about six leaved.

Bi-per-annual? Culm 1 to 3 feet high, rather stont, tuberous at base; leaves nearly as long as the culm, keeled; umbel three to nine rayed, rays unequal, two to six inches, the central one suppressed (i. e. spike sessile) spikes 1 to 2 inches long, often compound, yellowish; spikelets numerous twenty, sixty, to eighty, about $\frac{3}{4}$ inch 
long, eight to ten flowered, spreading on all sides, finally a little reflexed; akenes triquerous, oblong, rough-dotted.

Hab. Wet meadows, \&c. Aug. Sept.

Obs. The plants of this Gentis are variously rendered in the books, but I think that they are all annuals, and bi-annuals, except the tuberiferous species, which become spurious per-annuals by reason of their bi-annual tubers.

This plant is a useless incumbrance in damp meadows but is more particularly introduced here on account of its near relatives- $C$. repens, and $C$. hydra-which are deserving of special notice.

\section{C. REPENS.-Elliott. Nut Grass.}

Rhizomas fibrous, creeping, tuberiferous, at the extremities; spikelets linear, obtuse, rather crowded, in somewhat distichous spikes; involucre three or four leaved.

Bi-per-annual? 'Tubers of the rhizomes, about the size of a pea; culms 1 to 2 feet high, glabrous; leaves 10 to 20 inches long, keeled; umbel four to six rayed; rays 1 to 3 inches in length; spikes 1 to 2 inches long; spike. lets $\frac{1}{2}$ to $\frac{3}{4}$ inch, ten to fourteen in each spike, somewhat spreading, each twelve to twenty flowered; akenes triquetrous, minutely punctate.

Hab. Fields, lots. Aug. Sept.

Obs. I have no good and authentic specimen of this, or the following plant, nor have I had the opportunity to examine their habits. Dr. Darlington says: "This is a great pest, where it gets possession of the soil-and requires prompt attention, for it multiplies rapidly. It is not however, quite so bad as the C. Hydra of the South. It is now becoming rather alarmingly abundant, in some localities." "West-town. West Chester."

\section{C. HYDRA.-Mix Coco Grass}

Rhizoma creeping, tuberiferous; umbel mostly simple, three to four rayed; involucre two to three leaved, ahont as long as the rays; spikes distichous; spikelets four to nine on each ray, lance-linear, acute, much compressed, ten to forty flowered, dark chesnut-purple.

Bi-per-annual? Rhizomas terminating in tubers, nearly half-an-inch in diameter ; culm 2 to 12 inches high, smooth, triangular, naked; leaves all radical, shorter than the culm, about two lines wide, acute, slightly channelled, often recurved, somewhat glaucous; involucre sometimes, shorter than the umbel; rays of the umbel 2 to 3 inches long, erect, or slightly spreading; spikes near an inch long, alternate and distichous, along the upper part of the rays; the scales closely imbricated, bright chesnut-color, with a green keel, not nerved, mucronate; styles three, united below, distinet at summit; akenes triquetrous.

Hab. Fields and waste places.

Obs. Elliott as quoted by Darlington says_"This is becoming a great scourge to our planters. It shoots from the base of its stem, a thread-like fibre, which descends perpendicularly 6 to 18 incires, and then produces a small tuber. From this, horizontal fibres extend in every direetion, producing new tubers at intervals of 6 to 8 inches, and these immediately send up stems to the surface of the earth; and throw out lateral fibres to form a new progeny. This process is interminable-and it is curious to see what a chain, or network, of plants, and tubers, can, with some care, be dug up, in a loose soil. 'The only process yet discovered, by which this grass can be extirpated, is to plow, or hoe the spots in which it grows, every diy, through the whole season. In their perpetual eflorts 
to throw their leares to the light, the roots become exhausted, and perish. Or if a few appear, the next spring, they can easily be dug up."

Through the same channel, J. S. Skinner says, that the Coco Grass "Is the vilest of all pests, which has taken possession of, and caused to be abandoned; some of the best sligar estates in Lonisiana. Of all things, it is said to be the most tenacious of life; and nothing serves so well to propagate it, as to plow, and re-plow, with a view to destroy it.

\section{Order. XXXIV. GRAMINEZ⿱一𫝀口.}

True Grasses, mostly with hollow, cylindrical, and jointed, stems (culms); leaves alternate, two rowed, parallel nerved, the dilated petiole (sheath) surrounding the culm, and split open on the side opposite to the blade, and furnished, at the junction with the blade, with a more, or less, manifest scarious appendage (ligule); Flowers perfect, polygamous, or monoicous (rarely dioicous ; imbricated with two ranked glumes or bracts-the onter pair (glumes) subtending a spikelet of one, or several flowersthe inner pair (palce) enclosing each particular Flower, which is destitute of a proper perianth;-stamens one to six, usually three; -anthers verticillate; ovary one celled, one oruled, usually with two to three scales (squamula) at base; styles mostly two, or two parted; stigmas plumose, or hairy-Fruit a seed-like grain (caryopsis);embryo small, at the base, and on the outside of copious, farinaceous albumen.

Annuals or Per-annuals. - With fibrousr oots, often cespitose, spikelets panicnlate, or spiked; upper (inner) palex two nerved, or two keeled.
This rast family of plants - while it furnishes most of the Food-plants for man, and the larger animals:-also inflicts upon the agriculturalist some of the worst pests which have ever invaded his premises, as the sequel will show.

\section{Tribe CHLORIDE五.}

Spikelets rarely one-usually several flowered, with the upper, or terminal, floret imperfect; disposed in one-sided, racemose, or digitate spikes; glumes persistent-the upper, appearing as the outer one; rachis not jointed; stamens two to three.

\section{Genus. LXX. CYNODON.-Rich.}

Spikes digitate, in pairs, or racemose; spikelets with one perfect floret, and sometimes the subulate pedicel, or abortive rudiment of a second, superior floret; glumes, keeled, awnless, nearly equal, the upper one cxterior; palere membranaceous, the lower one keeled, acute, awnless, or sometimes mucronulate, the upper one two keeled;scales two, fleshy, mostly connate; stamens three;-ovary sessile, glabrous; styles two, terminal ;-stigmas plumose, with simple hairs; caryopsis free, inclosed in the palea.

\section{C. DACTYLON Pers. Bermuda Grass. Dog-tooth Grass.}

Spikes three to five, digitate, spreading; palex longer than the glumes, glabrous, somewhat ciliate, with a beardless bristle at the base of the inner one.

Per-annual. Root fibrous, creeping, with numerous slender rhizomes; stem procumbent, radicating 6 to 12 or 15 inches long, terete, smooth; leaves 1 or 2 , to 4 inches long, acute, somewhat distichous, and rigid, slightly hairy, and 
scabrous; sheaths longer than the internodes, hairy; ligule berrd-like; spikes three to five, (usually four) - 1 to 2 inches long; rachis flexuous, and angular, not winged; scales obovate, half as long as the ovary; stigma dark purple.

Hab. Loose sandy soils June. Aug.

Obs. I have copied Darlington from Elliott. But the latter says, "We have two varieties of this plant-one coarser (perhaps a species) growing in damp soils. native; the other, deseribed above, said to be imported, a tender, delicate, grass, growing over, and binding, the most arid, and loose lands in our country; and, apparently, preferred by stock of all descriptions, to every other grass. $* * *$ But it grows in every soil; and no grass, in close, rich land, is more formidable to the cultivator; it must, therefore, be introduced with caution."

The latter remarks may have been intended to apply to the coarser form, of the plant; and fully corresponds with my own observations in eastern Virginia. The smaller. form I have not seen; but they seem to differ, mainly, in their proportions. One, the stem 6 to 15 inches long, the other (collected on the James River, at Richmond, full 5 feet long, and branched. This may be the result of soil and circumstances.

In the autumn of 1846 , I had an opportunity of seeing this grass in its full proportions, on the farm of my friend Dr. Dupuy, near Petersburg, Va. Being both rhizomatous and stoloniferous, it is doubly armed, for mischief. While the rhizomes are spreading below the surface, and sending up new plants, the stolons are creeping above the surface, rooting at their numerous nodes, and sending up vertical stems, for flowers and fruit.

Dr. Dupuy had, sometime previous to my risic (I think four weeks) plowed, harrowed, and thoronghly tilled, a piece of ground, preparatory to wheat. In the short time which had elipsed, the lot had been completely overrun, and covered, with a new growth of the Bermuda Grass. It seemed to have taken complete possession of the soil. The rhizomes were already coming to the suafice, to form new plants; while the stolons, or creeping stems, now 12 to 18 inches long, had formed roots, at their numerous joints, and were sending up, erect stems for flowers, and fruit.

There was much labor due to this ground, before it could be seeded, with any prospect of a crop. This could only be applied, by the judicious use of the plow, harrow, rake, and fork, to drag out, and collect the squitch.

Whethẹr such a nuisance can be thoroughly eradicated, I do not know. But each noxious weed, as it passes in review, repeats the imperative lesson, of early and strict vigilance, to crush the first buddings of mischief.

\section{Tribe. FESTUCINEAE.}

Spikelets several flowered, often with the uppermostrarely with the lowest-floret, imperfect, or abortive; usually disposed in open panicles; pale:e pointless-or the lower one sometimes tipped with a straight awn, or bristle; stamens one to five; scales two.

\section{Genus. LXXI. BROMUS.-Linn.}

Spikelets ovate, or oblong-lanceolate, compressed, five to many-flowered, in a loose panicle; glumes unequal, the lower, one to five nerved - the upper, thiree to nine nerved; lower palea convex, bifid at apex, usually awned a little below the tip; upper palea pectinate-ciliate on the two keels, finally adhering to the grooves of the linear-oblong grain ; stamens three. 
OR, WEED EXTERMNATOR.

Coarse grasses, with rather large spikelets, which are finally nodding.

Culm 2 to 4 feet high, smooth above; nodes black; leaves 6 to 12 inches long, pilose on the upper surface; sheaths nerved, the lower ones retrorsely pilose, the upper ones to five ; panicle very loose, the branches in pairs, or three to five, slender, subdivided, flexnous, and sharply scabrous ; spikelets about ten flowered; lower glumes smaller, almost subulate, one nerved; the upper one three nerved; lower palex seven nerved.

\section{B. SECALINUS-Limn. Cheat-grass. Chess.}

Panicle-branches nearly simple; spikelets ovate-oblong, somewhat turgid; florets smooth, distinct, longer than the flexuous awns.

Annual. Culm three to four feet high, smooth, nodes pubescent; leaves 6 to 12 inches long, rough, and pilose on the upper surface; sheaths smooth; ligule oblong, semiate-dentate; panicle 4 to 8 inches long, the branches semi-rerticillate, rough and pubescent; spikelets eight to ten flowered; lower glume shorter, five nerved, sometimes mucronate; the upper one seven nerved, obtuse, or emarginate; lower palex obscurely seren nerred, slightly pubescent near the apex, the awn sometimes wanting, or a mere rudiment; grain closely embraced by the lower palex; the upper palen doubled in the grove, and adherent.

Hab. Among wheat, \&c. Europe. June. July.

Obs. All wheat growers are familiar with this miversal pest; and many have, no donbt, taxed their ingenuity to abate the nuisance. with what dexed then ingennity to whent fields will testify. should should ever be-Clean Seed-Clean Manure-Clean
Soit-without which he can not rationally expect to have clean crops.

There ale some sorts of weeds which occasionally appear suddenly, in great abundance-or having been abundant, as suddenly disappear. The Pigeon. Weed, and St. John's Wort, have been mentioned as examples. On Cheal Grass been called Meteoric, from a fancied connexion between changes.

In the autumn of 1848 I put down a field of $6 \frac{1}{2}$ acres, to wheat and grass; and in order to sccure a good pastme, I sowed a very liberal allowance of Timothy-Orchardand Green Grass seed, and in the spring, clover. The Wheat crop was the best I ever raised, (an average of 2.5 bushels per acre); and the growth of straw was very heary; but the grass was a complete failure; being apparently smothered ont by the redundant growth, and tangled condition, of the straw. In the spring, howerer. there was a consirlerable promise of young grass. But, of cheal grass. I sold the crop to my neighbor Job Yerkes to be cut for hay, for $\$ 6$ per acre $(\$ 39)$ on condition of it being carefully cut before the seed was matured. This was a prety heary cheat transaction, but my friend appeared to be well satisfied to be cheated in that manner; although I do not suppose that he obtained fifty pounds of anything but cheat.

I am not a believer in the transmutation of either declined the ancestral honor of a direct lineal descent from some renowned Grandpaternal Oyster, or Bull-frog. Nor can I armit, with any better grace, that my crop of cheat sometimes assumes the same erratic habit. They have some peculiar condition of the atmosphere, and those as the season arranced, it was found to consist, wholly, animals or plants. I ever have, with maffected modesty, 
was a transmuted growth from Wheat, scattered in gathering the harvest. Wlence it came I do not lnow; and prefer to be truly ignorant, than falsely wise.

\section{Tribe. HORDEINEAE.}

Spikelets several flowered, sessile, on opposite sides of a flexuous, toothed rachis, forming a solitary spilie; the terminal, or lateral florets often abortive, glume sometimes collateral, or wanting; palex awned, or awnless; stamens mostly three.

\section{Genus. LXXII. TRITICUM.-Linn.}

Spikelets three to seren flowered, compressed, with the flat side against the rachis; florets distichous; glumes nearly equal, and opposite; lower palex very like the glumes, convex, awned, or merely mucronate; the upper one flat, bristly-ciliate on the two keels, free, or adlierent to the groove of the grain; ovary pubescent at summit.

\section{T. REPENS.-Linn. Couch Grass. Squitch Grass}

Rhizomas creeping; spike compressed; spikelets four to eight flowered, lance-oblong, acute; florets mostly awnless.

Per-annual. Rhizomas jointed, white; plant sometimes, bluish glaucous: culms 2 feet high, smooth; leaves 4 to 12 inches long; sheaths smooth; ligule short, truncate; spike 3 to 5 inches long; rachis flexuous, flat, mostly scabrous on the margins; glumes acuminate, keeled, strongly five to seven nerved, roughish, the outer margin broader; lower palex acuminate, or mucronate, five nerved, smooth.

Hab. Fields, \&c. Europe. July. Aug.
Obs. This is properly, the Couch-Quitch_or Squiteh grass, of English writers; although in Agricultural phraseology, they include several weeds, of somewhat similar habits, and apply either term to the refuse mass, which is gathered out of their foul lands.

The Botanical Editor of Reeses Cyclopoedia says of this grass_" The long, and deep creeping roots, are, of all things, the most difficult to extirpate." In many of the best lands in England it is so rampant that they seem to despair of ever eradicating it; lut by a sort of compromise, agree to surrender something like every seventh crop, to a Summer Fallow, in order so far to clear the soil of Squitch, that they can obtain the other six crops, with less detriment.

When it occurs only in small patches, the timely application of some of the methods suggested in this work, will be found adequate to accomplish its destruction. Nore especially those for Toad Flax and Canada Thistle. But where it occurs on a broad scale, it will require the united aid of the Brotherhood for its eradication.

\section{Genus. LXXII. LOLIUM.}

Spikelets many-flowered, alternate, distichously arranged in a simple, terminal spike, with the edge of the spikelets to the common rachis; glumes, (except at the terminal spikelet) only one, and that on the onter side; for the rest, much resembling the Couch Grass. Grain adherent to the upper palere, smooth.

\section{L. TeMULENTUM.-Linn. Darnel. Bearded Darnel.}

Glumes awnless, longer than the spikelets; spikelets five to seven flowered, ovate, compressed; florets each with a short awn. 
Annual. Root fibrows: culms few, two to three feet high, smooth below, rough above; leaves ribbed, rough; stipules short, crenate.

Ilab. Among Grain. Europe. June. July.

Obs. The Darnel, being an annual weed, of quick growth, it is indifferent whether the seed was sown with the Grain, or inhered in the soil, it readily springs up with, and accommodates itself to, the grain crops, wheat, rye, \&e.

It is feared that little can be done to separate the Tares from the Wheal, while growing in the field. But this cannot be too carefully attended to, when brought into the barn. The separation must be made, and the foul seeds destroyed (not allowed to pass into the barn-yard); or the eonsequences will become, more and more disastrous.

This separation of the Darnel seeds, acquires greater significance, from the fact, that they are, and have long been, reputed to possess, noxions, or poisonous, qualities, when made up into bread.

Lindley says, "Its eflects are undoubtedly deleterious." Another- "The seeds are said to be intoxicating, to men, beasts, and birds; and even to bring on convulsions and death."

Linneus, gave the specific name temulentum-with a direct reference to its intoxicating qualities. And even Virgil, wrote "infelix Lolium."

This deleterious question can only be decided by direct experiments; and as the Eastern Pennsylvania Model Farm is thought to have the most ample material; I hope its managers will give their attention to the subject. It is cause of deep regret, that this, or any other, noxions weed, should find a Home on the FARm. It would seem to be within the province of the MoDEr, to guarl, with sedu- lous care, against the introduction, or the dispersion, of noxious seerls. And should any such, mufortunately, gain admission; to exemplify the most certain, and expeditious means for their eradication. If these precautions be not observed, instead of its being a valuable adjunct to the agricultural interests of the District; it may yet come to be the salient point of an ummitigated nuisance.

\section{Genus. LXXIV. CENCHRUS.-Limn.}

Spikelets, as in Panicum; awnless, but inclosed (one to five together) in a globular, bristly, or spinous, involuere, which becomes coriaceous, forming a deciduous bur, in fruit; involucre sessile, in a terminal spike; scales none, styles united below; grain free, included in the palex.

100. C. TRIBULOIDES._timn. Bur-Grass. Hedge-hog Grass.

Culms branched at base, geniculate, ascending, or procumbent; spike oblong; involucre spinose, pubescent, split on one side.

Annual. Culm 9 to 18 inches high, smooth; leaves 3 to 8 inches long; - sheathes loose, smooth; ligule beardlike; spike terminal, consisting of six to twelve, or more, alternate, involuerate, heads, or clusters; rachis angular, flexuous, slightly scabrous; involucre ureeolate, or subglobose, laciniate, armed externally with, subulate, scabrons, spines, villous within, embracing one to three spikelets; sterile floret mostly staminate.

Hab. Fields. Sands. Aug. Sept.

Obs. Those who have experienced the annoyance which this "pestiferous" weed occasions, would hardly consider any labor too great for its destruction. With a quick 
growth, and plenty of seed, it will soon insinuate itselfinto every nook and corner, and bid defiance to any ordinary means for dispossessing it. Though it seems to belong to sands, it developes itself in all soils in proportion to their fertility. I have gathered it in the sands of Jersey 2 inches high; and in the Hockesson valley 18 inches.

I can only recommend careful tillage, with plenty of hand-hoeing, and hand-weeding. Unless these means be assiduously employed; whatever may be the effect upon the horses; their drivers may find themselves somewhat affected with the scratches.

\section{GLOSSARY}

OF TIIE

PRINCIPAL BOTANICAL TERIIS USED IN THIS WORK.

The reader will bear in mind, that where compound descriptive terms are employed in this work, the last member of the compound word is intended to give the predominant character,-and that the word or syllable prefred, merely indieates a modificalion of that character:-as, for example " ovatelanceolate" signifies lanceolate, but inclining somewhat to ovate. while " ovateovale" means ovate with something of the lanecolate form onc. "yellowish-green," "bluish-green" of signify that green is the peraing hos. but that it is tinged with a shade of yellow, blue do. Ters in prevailing hue,of any organ, or portion of a plant-ns "large" "small" or "micative of the size of course, relative,-and have reference to the usual or average sized "-are, parts, or orrans, in other suce of such parts, or organs, in other species of the same genus, o: family

Abortion, an imperfeet development of

Abortive, not arriving at perfection Alroducing no fruit.

Alruptly acuminate suddenly narrowed to an acumination.

Abruptly pinnate. See Even-pinnate. Aecessory additional, supers. accu. Accumbent cotyledons, having the raalong the edges of the cotyledons represented by this cotyledons in some Tetradymamous or crue ferous plants.

Acerose, linear and needle-like, - as Juniper leaves, de.

Acicular, needle shaped.
Acrogenous plants. Plants which grow or develop from the apex or summit,

nous plants - whichers, or acrogeAculeate, prickly; armed with prickles. Acuminate anding in litte pricks pering point.
Acumination. An extended tapering point Acute, sharp; ending in an angle, or
point; not rounded. ancrent, attached to, or united with Anate, adhering laterally; fixed or growing to. and petals are arranged in the flowerftermath the expand.

grasses in the sane seasth of the being cut off. Aggregated, crowded, or standing toAkene for the same receptacle. with a dry indehiscent peril frmit often bony or muttilie. Alae. Wings, or membranous expan Alcte, winged; having a membranous border. Abumen. A deposit of nutritive inorGanic matter, distinct from the em sometimes (as in the seeds, - and stituting their chief bulk

Alternate, not opposite; placed alternately on the axis, or receptacle.
Alveolate, having pits, or colls lite honeycomb.
Ament. A slender spike of naked and lyx tube to the ovary 0 . as the ea

not produced natuing irregularly Aestivation. The mode in which sepal Abuminous seeds, furnished with, or 
usually diclinous flowers, with in- Areola. A small cavity,-as in the base Amplexicaul, embracing or clasping
the stem.

Analogue. A body or organ resembe ling, substituted for, or equivalent to, another body or organ
Anastumosing, applied to branching
ressels which inosculate or unite again, like net-work. Anatropous ovule, or seed. Turned: inverted on the funiculus, so that the placenta. Ancipital.two-edged; somewhat flatted Inith opposite edges.

pistillate flowers distianizate and sime spile or pint

Angiospermous, having the seeds con-

tained in a distisct pericarp or seedAngulate, having, angles, or corners, Anisate, reombling anise-seed, in Annotecineror, applied to leaves, se. Amotches, applied to leaves, Se.,
wnich are annual, or renewed every A searual, living or enduring but one Anmular, in the form of a ring. Ammutate, having a ring, or belt. system; forming an exception to Anterior, in front, - as that part of a Anther. 'The linoti, or capsule, con ported the pollen,-lusually supAntheridia. The analognes, equivaJents, or representatives of Anthers. Antheriferous, bearing Anthers. ing a corolla.
ipex. The summit, upper or outer end. Aphillous, destitute of leaves
Apothecia. 'The enps, or shield-like receptactes of the fructification of the Appendiculate, having some appendA proressed, pressed to, or lying close Approrimate, growing or situated near Aquatic, growing naturally in water, Arachnoid, resembling a spider's web Arborescent, approaling the size or height of a tree.
Arcuate, curved, or bent like a bow.
Arillus. An expansion of the fumcurus Armed? hre processes. Aromatic, having a spicy priekles. Articulated, jointed; connected by joints, or places of separation. which articulated members are sepscending, rising from the ground obAssurgent, rising in a curve from a deAuriculate, having rounded appendages at base. like ears. Awn. A slender bristle-like process,common on the chatf of grasses Awned. furnished with awns, or bristle Awnless destitute of awns. Axil. The angle between a leaf and stem, or branch, on the upper side.
Axillary, growing in, or proceeding Axis. A central stem or peduncle. a real or imaginary central line ex tending from the base to the summit,
Bacate, berried.-becoming fleshy or Bald alsent, like a herred at summit ; destitute of pappns or crown.
Barb. A straight process, armed with one or more teeth pointing backBusilar, originating at, or aftixed to the base of another organ.
Beak. A terminal process, like a bird's Bealed, having, or terminating $\mathrm{m}$, a Bearded, erested or furnished with parallel hairs: the term is applied, Berry. A pulpy valveless t1uit, in which the seeds are imbedded.
Bi-annual, continuing for Bi-annual, continuing for two years;
producing flowers. and fint the second season, and then perishing. Bibracteulate, having two small bracts, or ensps, ending in two sharp point
or often fleshy) coating of the seed and Aristate, awned; having awns, or Atenuated, tapering gradually until it bractlets, or bracteoles.
Biennial, same as bi anmel.

Bifarious, in two series, or opposite Bijid. two-cleft, or split into two segBifoliate, having or producing two Bifurcate, forked; ending in two equal Bi.gibbous, having two hunches, or gibbons productions.
Bi-glandular, having or producing two Bi labiate, having two lips.

Bilabiate, having two lips.
Bilamellate, hiaving two lamellae, or thin plates.
Bilocular, having two cells. Bipartible, separable into two parts Biprer ammat. Applied to certain muals, in flowers, frute and decline but by virtue of a super added finnehon; the production of Rhizomes,
in the form of rootstocks, bulbs and tuber: they beenme per :mmials.
Bipinnate leaf. Twice pinnate: common petiole having opposite ing opposite articulated leatlers. Bipminatifid leat. 'The common petiole
bearing opposite pinnatifid ses bearing opposite pinnatif
ments. Bi rostrate, having two beaks. Bisulcate, having two grooves or furBiternate leaf, twice ternate; the comdivision oi branch, boning theh leatlets. Bivalved, haring two valves.

Bitentricose, having two bellied or dis. Blom. A tine powdery enating on certain fruits de, as the plum.
Bowol shepert. hemisuherieal ind conBowl shaper. hemispherical and con-
cave. of hollow. like a bowl. Brachiate, having the branches spreadBract. A tloral leaf; a moditied leaf, from the axil of which arises the Bracterte, furnished with bracts, or moditied leaves among or near the Howers.
Bractenles, or Bractlets. Small bracts. Bractenles, or Bractlets. Small bracts.
Braclless, destitute of bratcts. Brenchlets. Small branches, or subdivisions of branches.
Bristles. Stiftish elastic hairs, straight Bul. A growing point, or undovelnped axis, covered with the rudiments of
Bulb. A kind of bud, formed of fleshy scales, or coats, and usually seated
on the neck of the root, - sometimes Bubliferous, bearing or producing
bulbs. Bulbous, formed of, or like, a bulb. Bullate leaf, having bubble like convex-
ities on the upper surfice, with corities on the upper surface, with cor-
responding carities beneath. Cudueous, falling off immediately, or Calcarate, spurred; having a process
like a horn, or spur, -usnally horlow. Callons, firm and yristle-like. Callus. A compaet gristle-like tuCulyciform, shaped liko a ealyx. Culyculde having an additional (nsuCulyptru. The eap, or hood (resenbling the extinguisher of a candle, on the fructification of the mossen.
Calux. Thie flower-cup, or onter (and Calyx. 'The flower-cup, or onter (and
sometimes the only) covering of a fluwer, nsirally green.
Cumpanulate, in chie form of a bell. cumpylutropous orule, or seed. Where the ovule curves upon itself, and
thms brings the orfice, or apex, near Canaliculate, ehims.tined or furrowed. Canescent, hoary: clothed with $\mathrm{a}$ whit. Crapillaceous, or copillary, long and fino, or stender, like a hair. hurate or grobular mass. Capsulur, resembling, or being, at cirpCupsule. A dry hollow seed vessel,uwially opening by regular valves, Carinal. belonging to the keol, or Curinate, ke led; having a ridge on the back, like the keel of a boat. Carpel. A little fruit; usually a partia pistil, or constituent portion of a compound firtit. bearing the earpels,-as in UмвнLLif:cupophylls. The modified leaves wheh form the pericarp, - as in the rtilaginous. hard yet somewhat flexCaruncle. A iteshy exerescence, sometimes found at the hilum of seeds. ary'psis. A fruit where the periearp
is very thin. indehiscent, and closely 
118

GLOSSARY.

as in the grasses, cyperaceac, dc. See Circinate, with the apex rolled back on

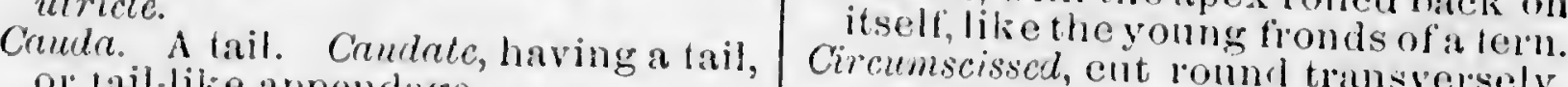
Canlescent, havine an evident or true or openning horizontally, like a snutif-

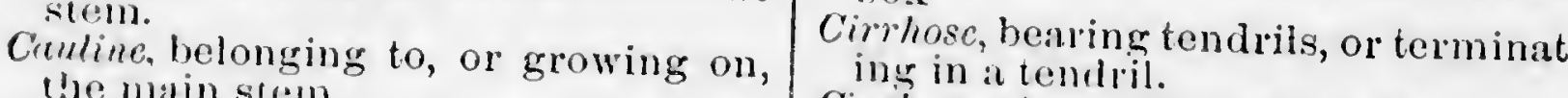
Cellutar, male up of little cells, or cavities, formed of membranaceon Celluler plants. The lower orders of flints (including the messes, ane clusively of eellular tissue.
Centrifugal inflorestence central fluwer of ance, where the mences at the eentre and ong comsuccessively to the ciremmferente.
Centripctal intlorescence where the onter flowers of a corymb or umber precede the inner ones, $-i$. $e$. the
flowers expand in succession, from
the circumterence to the centre.

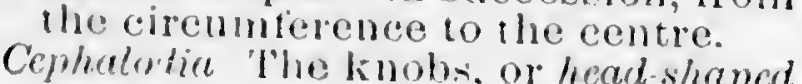
iruetifications, of some of the Lacit:Cereal, pertaining to Ceres; belongins to those farinaceous grains, or seeds, of Which bread is made,-and over
which the goddess Ceres was supposed, by the ancients, to preside. Cerneous, nodding; the apex or sum-
mit drooping, or turned duwnward Cespituse, having or many stems growing from the same root forms growing or tussock. Chatf. A dry membrane,-usually the
small husks, or seed-covers, of the small husks, or seed-covers, of the
griases; also the bracts on the re ceptecle of many compound and other aggregated flowers.
Chaffy bearing chatf; also resembling Chaffy, bearing chalf; also resembling
chatt. Channcls. Longitudinal grooves; the firuit of umbelliferons plants Chathelled, groured or finrrowed.

features of objectsal History). The jects, by which they are linuwn. an distingtished from each other. Chartaceus, of a texture resembling Cicut rice. A scar,- - such as that left at the place of articulation after the Cilia. Hails arranged like eye lashes, along the maryin of a surfite. Ciliete, fringed, or edged with parallel hairs, like eyo-lashe

cilateserrale, having sermatures re Cincreans, of the colsht eye-lishes.
Crrrosc, bearing tendrits, or terminat-
ins in at endril. Class. One of the higher or primary
divisions of plants, on other natury Clavjects, in a systematic arrangement Che choshaped; thicker towards Claveliate, in the form of a little club, Claw of a petal. The slender taperin Cleft on at bave, or below the middle Clcft, split, or divided, less than lalf
way to the base: sometimes the di vision itself is called a cleft. cypcate, in the form of an ancient Cocetancous flowers, appearing at the Coarctate, contricted, or erowded into Cocens plural eocei). A kind of semi-

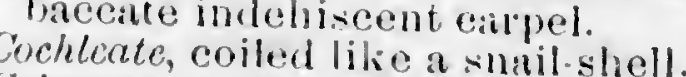
coherent, united with an orsan of the same kind,-as stumens colierent Cotumella. A little columm. comen. The axis or central pillar of and style of a Gyumbined filament. daceois plant. Coma. A terminal tuft of hair, bracts. des.
Commissure. The line of imetion of mment (petiole, peduncle, se.) longing to, or stustaining, several

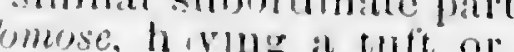
histrs, bracts or leaves, topknot of Compret, cundensed, or pressed to Complete flower, having both ealyx and eorollat. Cumpoumd, not simple,-but made up
of similat simple pirts. Component flmoer. An aggregated chlyseated on a common receptacle any embraced by an involucre, or manyComponmed cominon caly $x$ leaflets, or laminac, each orticulated with the common petiole, and ullimately falling trum it. Cirbus. A tendril,-which see withereh other, se. see adherent. the same side of site hy side; or on Colercel, of any other cerlur than sreen. two bodies, - as the face of the call pels (or mericarps) in Unum the can-
GLOSSARY

Componen Orary. Consisting of two or 1 of a round or oval figure, and an more carpels, or simple ovaries, co- $\quad$ minform eompact texture, as in the
hering together. Compentum Umbel. An umbel in which each primary peduncle, or ray, bears Commoressed, Hatted, as if squeezed or Cumpressed Aliene (in compound flowers, flatted, with one edge to the pressed. Concave, presenting a hollow or dePressed surfaco.

or circles. Circles , or diameters, with Concrete, grown together, or united. folded together like a sheet of paper, or the leaves of a book. Cone. The woody ament of the pines; anic the fruit of the hop, se.
Conic, Conical, or Conoid, having the Confluent. blended, or rumning toCongerer. A plant belonging to the come genus: nearly related. Conglomerate, clustered or heaped toConjutgate, in pairs; compled. Cominte, growing together, or coherCommective, or Connectivum. The organ inther, conspienous in some of the Comivent, the summits meeting, or benthing townds each other. Comstent, invariable; also never failConfigurs, so neir is to seem to tonch. Continums, without interruption, or anticulition. Conturted, twisted ; or obliquely over-
latipns. Comtractad, narrowed, or reduced into contrery diswepiment. Not parallet, but at right angles. or nearly so, Concex.presenting an elevated rounded Concolute, rolled into a cylindrical form. Coralsid, resembling cural, in appearCimdete, heart-shaped, with the sinus or notch at the base.
Cordate oblong, oblong, with a cordate Coricecous. tough and leather-ike. Cormophytes. Plants having a stem, or axis of growh. Corneous, having the consistence or Corneaculate, having littlo horns or Sormeutate, having littlo horns or
spurs. Commete. havingappendages like horns. of the Hower, between the eally Coroniformens, mosthe shape of a crown. Corrmgated, contracted into wrinliles. Curtical, belonging to the bark. Cof ma. A mode of tlowering: a kmd elongated so as to forme peduneles Corymbose, in the manner of a corym. Cormmbulnse. having the flowers in hitle corvmbs.
Costate ribbed. Cotyledions. 'The seed-lobes, or first
crude leaves of a plant,-formed in the seed; and solnetimes becoming creping. rmming atong the ground, and putting forth small roots. Crenatc, nocked on the enlge. with the
segments ro mined, :nd not inclin.
ing towards either extremicy. Cicnulate vely timely crenter Crested, having an appendinge resembCrisp. curted. or wavy at the edges. Cross or cruss.theed hing a prest. mule,-produced hy the nixing of Crowded, thickly set; standing in eloso order. appendages at the throat of also of chatly seales at the summit Crowncd, having appendages resembCrenon shiped, resembling the figure Cruciate, weruciform, having four petals arranged in form of ta cross, ans in Tetrady namons thowers. Crustecons, having a dry britte shefl. destinte of visible genmine flowers. e ges rolled in so as to meet at bue ond spreading above, like a hood Culm. The stem

stem of the grasses, and Cherte or cuneiforin

tapering wirlorm, wedge-shaped bise Che cuplike involuere of the 


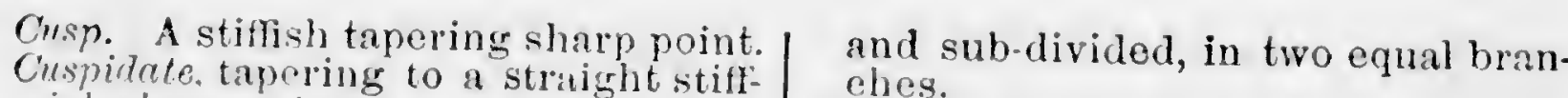
ish wharp point. Cuticle. The ont er skin,-usually thin Cylindric, long, round, and of uniform Cyme. A kind of panicle, depressed nearly to the form of an umbel, from the same centre, but the subCymose, with the flowers in cymes, or approaching that form. mose elusters of the cymes, or ey times called Verticittelters.
Dccandrous, having ten distinct staDecidrous, falling off at the usmal time. or at the end of the season: more durable than Caducous,- -which Declinate, or declinerd, bent off horizonDecompound, twice enmpound; posed of compound parts. Dccumbent, leaning upon the ground,
with the base on Decurrence. A rumning or extending down, or backwards. are continued down the stem, lifie wings.
Wecussate and alternately erosing each other Definite, elearly defined, or limited;
also of a constant or determinate (and not large) number. Deftecte i, bent off, or downwards. Dehiscent, gaping, or opening natu-
rally by seams, at maturity. Deltoid, triangular in the outline,Demersed, growing or being under Wense, closely arranged; compant. like projertions. Denticulate having very small teeth.
Depeupercited, with astarved on' stunted Depruperated, with at starved urstunted
inflorescence: few flowered. Depressed, tlatted vertically, or pressed down at summit.

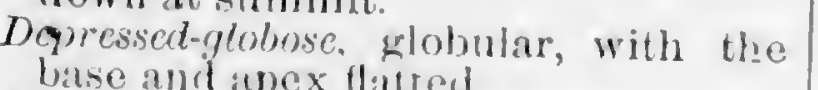
Diadelphous, having the filaments uni ted in two pareels; usually nine and Dicmirous, having two stamens. liyht to pass throught.
Dichotomal permiting of a dichotomons stem or brimet. Dichotomous, furl's; regularly duided
Diclinous, having the stamens and pisfils in distinct flowers.-Whether on Dicotyledonous plants. Where the embryo has two lobes. Wr cotyledons Didymous, twin; growing in pairs, Dind more or less united. shorter stamens, mostly in a bila. Diffuse, spreading widely in a loose irDigitate leat' Where simple petiolo conneets several distinct leaflets finger-like, at its summit,-as in tho Digynons, having two pistils, or two Dilalal, made wider; stretched or ex. Dimerous. composed of two parts,--as a limerons calyx or corolla, when
there are two sepals or petals. Dimiliate. hatred-as if one side, or Dim!ly. of a dull, soiled, smoky, or leaden-brown color. tillate flowers on tisminate and pisDiniconshy polygrmoms, laving perfeet Dipetalous, having two petals.

Discoid thower, or head. A disi of compound tiowers, without ray-florets. Discenthe having two sepals. the face or central part of a als of emmpound ilowers Dissecled, cut into segments, or lobes. Distant, having a larger intervening Distichous, two lowl. Howers, se., in two opposite rows. each other, nor with connected with Divricicate branches. Spreading so to form more than a right angle
with the stem aloue. Diverycht, spreading widely; making
a rikht angle, or nearly so, with tho Divided, separated or eleft to the base, -or to the midrib, if a leaf. Dorsal, belongung to, or growing on, Dorsul sulure. The line or seam on the back of a earpel, or lorded lear opposite of certral suture; which seo. the eells of the partition between
Dorsally compressed, flatted on the serted on itssummit,-as sepals. pe\begin{tabular}{l|l} 
Dots. Minute tubercles, or specks. & tals, and more especially stamens. \\
exemplified in Umbellifercae and Aru
\end{tabular} minute and slightly elevated points. Downy ethed witly soft fine hairs. Drooping, inclining downwards, mo Drupaceous, drupe-like, - of a structure resembling a drupe, or what is usu-
ally called stone-fruit. Drupe. A fleshy succulent, or snongy perieary, without valves, continingy an one or two-seeded nut, or stone. Drupet. A little drupe; a constituent
portion of a compound berry, - such Ebracteate destitute of himcts. Ebractcolate, destitute of bractlets. Ecandate, destitute of a caudu, or tail.
Eelinate, hedge hog like; covered with prickles.
Elaters. Minnte club-shaped filaments, which are coiled romd the spores
ond by maroling, assist in dispersing those sporer. Elliptic, or elliptical, oval, longer than
wide, with the two ends narrowing equally. age length.
Elingating, becoming gradually and finally elongated.
Emarginate, having a noteh or sinus at the end. Embryo. 'The young plant in the rulimentary state, as it exists in the seed. Emer'sed, raised unt of Water.
Lindocarp. 'That membranons or bony portion of the pericarp which line the cavity, or forms the eells for the seeds (c.x. pro the stone, or hard
shell, in a drupe) Endogenous plauts. Those which have a siugle cotyledon, - ind yrow by central deposites of new matter, distending or pusting the older deEndogens. Inside-growers; plants which increase by central or internal deposites of new matter. See Euncandrous, laving nine stamens. Ensiform, sword-shaped; two-edge and tapering from base to apex. Entire, having a continuous even mar-
gin; without incision, notch, or toot Einclope. An integument, or eovering. Ephemeral, diurnal; enduring one day Epicarp. The outer coating of the periearp, or fruit.
Epigynus, adnate to the ovary so that the upper portion is apparently inEqual, similar per selves, -as cillvx-segments, sepals, Equitont leaves. When alternate do tichous leaves are infolderl length wise and towards each other, the the inos inclosing or embracing Erect ovules, or seeds. When they arise from the buttom of the ovary, Wraded, or erose, irregularly notehed,
Erate at if gnawed by insects. Escutent. eatable; fit or safe to be eaten. biolation the blanching of plants,-
or fendering them white by the exclusion of light; as practised with or certainly,-ofien prefixed to the indicating their . vecuescent, disappearing; speedily Even-pinuate leaf. With the leaflets all in pairs, or without a terminal odd one; often termed abruplly pinnate.
Evergrcen, continuing green, and per-
sisting all the yeal calbuminous, destitute of albumen. Ecfuliate, to throw off layers or plates, -as bark, sc. Exogennus plants. Those which havo lwo (or sometimes more) cotyledons,--and grow by annual layers
of wood (or new matter) on the out side, between the old wood and bark. sugens. Ontside -growers; plants
which increase lyy annual additions to the outside. See exoychous xsert. or exserted, projecting, or protube of the corolla.
ristipulate, destitute of stipules. trorse anthers. Having tho cells tils,-and the tilament, or connective, extending up the inner side.
hlcate, sickle-shaped; curved like a Family of plants. A definite group of
kindred plants, called also an order, -sometimes of numerous genera ing but a single genus. Eu, a cireek adverb, meaning clearly. sickle, or scythe. 


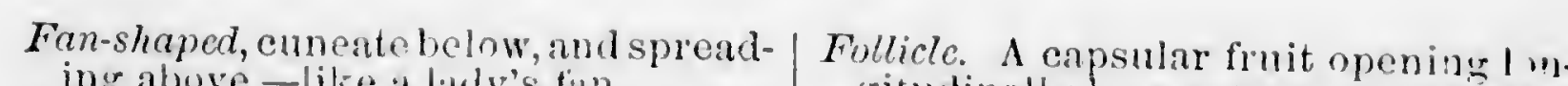
Farinuceous, mealy. reducible to a ritudinally by a suture on one s'de. meal-fike powder.

Fiscicle. A liule bundle, or bunch, of Foramen (phimil, foramina), a roundish thowers, leaves, \&c., originating trum Fasciculate, growing in bundies, or binches, from the same point. Festigiate, level-topped; the summits
of the branches all rising to the sane height. Favose, deeply pitted; somewhat like
at honey-comb.
Feather-veined lear. Where the lateral Feather-vined leaf. Where the lateral
veins (or nerves) diverwe regularly firom each side of the midrib, like the plumage of a quill.
Ferruginous, of the color of rust of iron; red lish-brown.
Fertice, having perteet pisils, and pro-
cheing flutit. ducing fruit.
Fibrous, composed of fibres, nr threadlike proeerses.
Fide, on the fitith, or anthority, of. (Insmally thread-1ike) which supports filcuill, fern-like; belonging to or reFilifirm, very slender and toreto, lite Fimbriad. Fringes, or fringe-like proFimbriate, finely divided at tho edge, Fimbrillate, elothed with fimbrillac (i. e. filuments) - as the rear or subulat

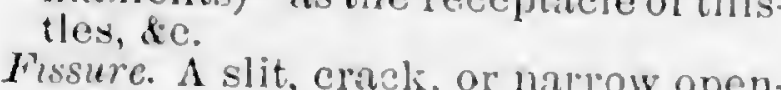
ing. $A$ sit, or pipe, tubular. Fitabelliform, fail-shaped, - which soe.
Fituceid, so limber as to bend by its F'agelliform, long, s' ender, and pliable, -like a whip lash.
Fexuose serpentine, or with a succession of whort alternating curves. Flocesse, or floceulcnt, eovered with
flocks, or thakes, or littlo matted burches of partly detached tomentum.
Floral, belonging to Flon'al envelopes. The vertieils, or cov erings of flowers, - usually known as Floret. A little flower; tustually one of
the mumber in compound or aggregated Howers.
feloriforous, bearing flowers. Foliacous, of a leat filke form and tex-
ture; resembling a leaf. Free, not adhering to each other, nor Frome, The loaf wi leaf-like expan. sion, of cryptoganons plants
frondose, leaty or with leaf like apFructifintion. The flower and fruit, with their parts.
rruit. The mature ovary ruit. The matire ovary or seed-
vessel, and its contents. "utescent, becoming shrubby, or hard Firuticose, shrub like, or shrubby. Fugacious, theeting; of short duration Fungous. of rapid grow hand solt texFuniculus. The little cord by which seeds are attached to the placenta. panding abore,-like a fiw, and exF'uscons, greyish-brown, or deep brown Fusiform, spinlle-shaped, terete and Gulen. A helmet; the arched upper lip of a ringent corolla.
Galente, helmeterl; resembling a casque, or helmet. Gamopetalous, having the patats all Gamssepulous, having the sepals all more or less united,-forming a Generic, pertaning or relating to a Geniculate, forming an angle at the Genus (plural genera). A groun of species whichatree with each othere ters of the flowere and fruit: so anetimes a genus comprises but a single species.
Germ. The growing part of a bud. Gimen. The old name for the oviry. Gibburs, hanched, or swelled out, on Gills. The frut-bearing membranes of the aygrics, or mushromms.
Glations very smooth without any Glatirous, very smooth; without any Glcun. A smalt roundish organ, or is ealied (rather neorrectly it noappendlage, which often secretes a
fludd.
GLOSSARY.

Glandular, furnished with glands.
Gluntulter-tispid, or wandular-pubscent, hairy or pubescent, and the
hatirs tipped with whyllous, having leaves of differGlaucous, silvery; pate bluis or groent ent torms. ish-white; covered with a greenish-
Icxamerous, consisting of six parts. White mealiness.
Globose or

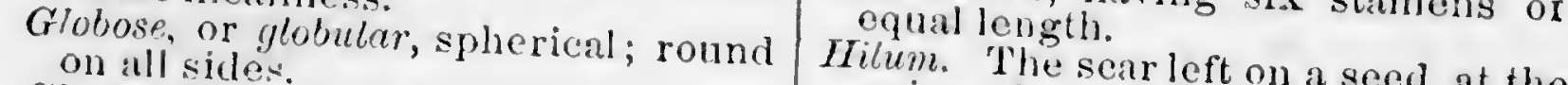
Glomerate, densely elustered in small point of attichment to the funicuGeaps, or trecrular heads in small Glomeruls. Small dense romndish Ghemaccous, chaff-like; resembling Glumes. The bracts, or outer chaff, embracing the spikelets of the $\begin{array}{cc}\text { Glumose, having gl ginnes } & \text { See paler. } \\ \text { (or, some- }\end{array}$ times, having ronspicuous ghimes).
Glutinous, viseid; coverud with and hesive fluid. Gramincous, grass-like; resembling
gratses. Granifer ous, bearing a grain, or grains.
Granular, tormed of gruins, or Gramular, formed of grains, or small
particles. Gynnuspermous, having the seeds naGynand ous, having the stamenus ing oll, or adrering ton, the pistil unbe. furmed by the connale tila ments of the Asclepices fomily.
Habit of plants. Habit of plants. Their general ex-
lemal appentance and mo growth, wy which they are recor nized at sy which they are recog-
und Hatitut, or hat tatio. The natural or

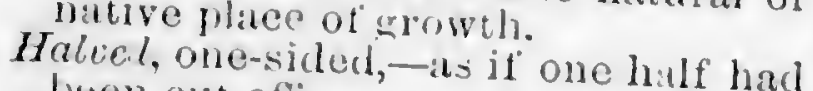
Hasiate, shaped like a halbert: lancenlate, wh a divaricite lobe on Head. A tence roundish eluster of
sestile fluwe rome Heptandrous, having seven stanens. Herfaceous, not woody; of at tender consistence, and usually destrueti.
ble by frost. Herbarime $A$ collection of dried speciHerbs. Planty which are not woodyof a more tender structire thian
trees and shrubs, and usually

Heterocephalous flowers. Heads of syn-
genesious florets of different character $i$. $e$. staminate aut pistit late theads distinet) on the sane Ieterogamous heads. Ileads of syngeHirsute, rongh-haired; clothed with
stiffish hairs. Hispid, bristly; beset with rigid, spreading, ,ristle-like hairs. ishy, covered with a white or whit Homoyamous h'ads. Ifeads of syngerets are of similar strueture and tho Inoodal. See cherlucter. Horizontal oviles. When they project
Irom the neither to base nor apex sembling a proess or elongation reHorny, of a texure or consistence like hom. Seecorneous. by the decomposition of soil, formed Hyative, Hybrd. A mule; a cross-breed tween two varieties, or nearly allied terent from both. Iymenium. The membrane contain Ing the sportules of cerain Fungi;
the plates. or gills, on the under sidu of the pileus of the anarices ander side Iypogacen, situated, growng, or reHypogenous, in erted beneath tho free from the sure receptacle, and Icon. An image, figure, or repiesen. Icoscendious having about twenty sta. mens, whieh are perigynous, $-i$. $e$. growing to, or apparent $y$ inserted
on the rim of the ealyx inicate, or imbricated, the edges $1 \mathrm{y}$. next series, -like regularly over the or seales on a tish. mperfect flower. When either staIncised out or are deneient. incisions. Thelinate, or inclined, bent over to-
warrs the ground, or some other
object tucluded, wholly contained within a 

or corolat is wanting. wards the summit upwards, or to- of inflorescence,-listally verticilIncumbent, lying upon, against, or imbricated series beneath or around Incumbent anther. Attached at or near its middle, and lying horizontally Incumbent cotyledons. Having the back of one of the cotyledons (represented by this sign, oll).
incurved, bent or curved inwards

Indefinite, not distinctly limited, or de-
tined; numerous, and of 110 constant fined; numerous, and of 110 constant Or determinate number.
Indehiscont, not opening at maturity. lindehenous, native; growing naturally, or originally, in a country.

Induplicale, folded inwards.
Indurated, hardened; become hard. which covers the young or veir chister of fruit) on the ferns. Inferior calyx. Having the ovaly Inf(ri,r ovary. Situated apyure

below the calyx, or rather its sey-
ments.-i. co adnite to the tube or ments. $-i . e$. adnite to the tube of
the caly $x$, und consequently heanthe the segments (ifiny) at its summit. Inflatcd, distended or swelled like a

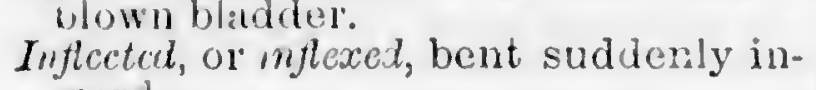
Inflorescenec. The disposition of an ringement of tiowers and their footpanicle. raceme, se. Interno ie. That portion of a e $1 \mathrm{~mm}$, or ttem, between the nodes or joints.
Inter petiolar stipules. Situa ed or or Inter petiolar stipules. Situa ed or ori-
ginating between the petioles of oppusite leaves. Interupted. having intervals; or the Intcruptecty pinnase, having smaller Intermptedy pinnate, having smaller
timne, or leatlets, between etch pair of larger ones. Intru-petiolar stipules. Situated with in
and above the petioies. - nstutly and above the petioies.-ustully
sheathing the branch above the sheathing the branch above the
axil of the leat; as in platumus. Introrse anthers. Hawing the eells
turned inwards, or towirds the pis ins.-anil the fintrent, or connect Inversely in a cout rary position; end for end, or upside down.
Inolucel. The verticil of leaflets at
the base of un unbellet Involucel hote, having insolncels. Incolucrate, having an involucre. Inv, inte, rolled inwards.
Irregular, the component parts differIrregular, the complonent parts differ-
iny in size and shape. Kicel. A longitudinat central ridge on the bark of a leaf, sepal, sc. resembling the lieel of a boat: Also,
the lower pair of united petals in a papilionaceous flower.

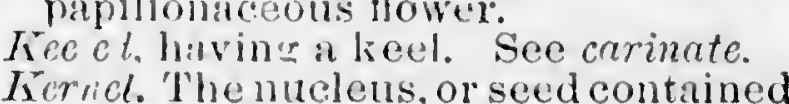

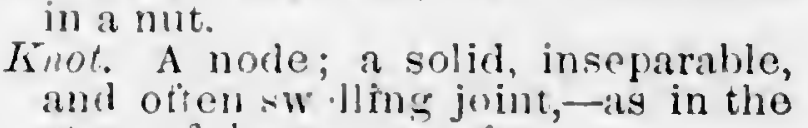
stem of the grasses, se. Lacerale divined into irregular segLaciniale, jagged: the margin irreguLutes ent, milky; containing a milky Lame lute. The plates or gills (hymenium of the ats Lamellate, divided or dilated into thin Lamina. A thin layer or plate; the petal, as distinguished trom the pe-
pertion of a late or tiole, or caly,
Lanate. woolly; clothed with wool. Lanceolate, tapering gradually from head of an ancient lanee. or spear. Lance-lmoar, lance ovate, de., linear,
ovate. \&e., with something of the a swelling tave and tapering apex. Lrmminons, clothed with a loose wool. Later ally compressed, flatted on the sides; the lateral edges pressed towatcds each other.
Lattical, obliquely eross-barred, with Laftets. Partial leaves; the constituent leaves of a compound leat.
Lent-like (folicceus) huring a textro Lcufy, (fintiosiss), furnished or aboundLeynme. A bean,-or fruit formed of the seeds affixed along the upper suture, only.
Leguminous, having the structure of a legume; bearing or prodicing tlio the heads of aygrewated flowers. Lance voride egr shaped. or terete, with Lax. louse, or limber"; not compart. and expansion resembling a leat.
Lenficular. having the form of a lens
orldicular and compressed, but convex on both fices.
Iigneuns, woody; of a firm woody Jigneuns, woody; of a firm woody tex
ture. Lignescent,beeoming some what woody. ped; llat and linear. penda the thisly membranous appendinge at the bave of the leaf, or Limb. The summit of a imonosepalous.
c:alyx; or the ufper spreaglins par of $y x$; or the upper spreading part tine. The twelfth part of an inch. Linear, of an uniform width; long and Lincar, w with parrillel sides. Lincar anceolale, dec. vartiking of both
forms, but more of the latter. Lip. 'The upper or under division of a labiate fower: or the lower perianth-segment of many orehinaceus
flowers. Lobe. The division, or segment, of a
petal, or leat: the free gaminopetalnus corolla.
Lobate, or lobed, cut or divided into
lobes or Luculicidal dehiseence. When the peri. a cell (i.e. at the dorsal sulue back of lectly into the carity. eral seeded legume, contracted between each seed, and finally separat Lomentaccous legume, nr pod. A pod like contraetion or tuensw a jonttition, between the seeds.
Lonyitminal, lengthwise; Lonfitancl, lengthwise; parallel with
the axis, or in adirection from the base towards the summit or apex. Lunate, or lumblate, having the figure
of a new moon. Lyrate, ly re-shaped; pinnatifid, with mostly rounded. Niarecsent, withering and shrivelling
on the stem, instead of filling Margin. 'The edste or of circumferene of a leat, or other expansion; also,
the thin wing-luke border of cortain Marginal, belonging to, or situated at, the margin. Marginate, or margincl, having a bor-
der or elying of a texture romuded by a wat of the disk; suror narrow membrane. expansion Mechullary rays. Bands or thin plates
of cellinar tissue, whieh pass thot of eelluar tissne, whieh pass from
the pilh to the bark, in woody stems.
sto the bark, in woody
and
Mclliferous, producing or containing Membrinaceons, or membranous, thin, cente, and often slightly translaMericarp. A name given to the inde. Micropyle. carpel of the UnibiLifiraf. opening in the proper coats or seed, to which the radicle always Midrib. The main central nerve of a leat, -apparently a
the petiole. Monadelphous. having the filaments all
united in one set,-usually forming a tube. Moncendrous, having a single stamen. ling the bearls of a like or resembpistils in the sang the stamens and Monorotyledonous plants whore embryo has but a single lobe, or coMonograph. A description (usually thing, or class of things, - as of a Monugymus, having but one

Imoirons having stamin one pislil tilate flowers distinet, but on the Holocicusly polygamons, having persame plant. Monmpetclus, having but one petal;
or, more correctly, the potals into ons see gumippetalous.
Minophyllous, consisting of a singlo leat. -or raher, several sepals united sepalons. Incronate, terminated by a muero, or prolongation of point,-ustarity the Mucromilate, having a small mucro, or Multifid, many ocleft; cut into numer. Miultiple. Antumber containing another number several times without a frac-
tion or remuinder -as nine is muliple of three. Linite truits. Where there is a enmaggregate mass-as in the pine-apple, mulber y, \&e. spreatined or covered with short preading points, or acute exeresMutic, or muticous, awnless or point.
Jess: the oprosite of mucronate 
\begin{tabular}{c|l} 
Nulicd, destitute of the usual covering. & $\begin{array}{l}\text { Obovnid, inversely ovoid. } \\
\text { or appendage, -as a stem withont }\end{array}$ \\
Obsolete. indistinet, as if worn out.
\end{tabular} leaves, or seales-leares withont pu or crown-seets withont a pericapa rereptucle without ehatt, or hairsan umbet withont an involacre, $\&$. Natural order, family, or tribe. An
atssociation or group of lindred genera - or of plants which are and most importantehares streture, Nectary. 'That organ, or portion of a flower. which secretes honey; a term formerly applied to all disguised or mens.
Nerved. having nerves, or coarse rib. Nirees. Kub like filires (in leaves, sc. ). which usual y extend from the ba $\mathrm{e}$ Ncuter, or neutral tlower. Having neither stamen nor pirtit.
Noding. timring downwards; somewhat dronping.
Nurle. The linot, or solid and of.en thmid joint, of a stem or tranch.
Nindusc. having mumerous nodes, or

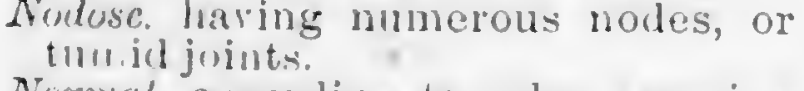
Nommal acenrting to rule; agreeing Nuciform naterike; resembling a nut. lecus. A central body; the seed, or Nucules. Little nuts, or nut like frnit. Nit. A hard one celled indehiseent
frint, usually containing a single $O b$, a preposition which inverts the usual incaning of the word to which
it i\& prefixed obcumpressed akenes (in the ConposITAE: Flattish, with the greatest diitmeter from right to left,-or will
the flatted side to the front, or perithe flatted side to the front, or peri-
phery of the heal. obcrmir, inversely conical.-i. co, with the point or apex downwards, at simmit. and the narrowed point Oblum'folate, inversely lanneolate, - or with the widest part above the mid.
dile, and tapering gradualy to the Ob'ique, a position between horizontal and ereet; also descriptive of the equat, or prodnced on one side.

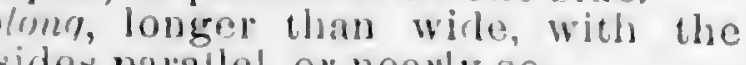
obovale, inversely ovate, -or with the
broadest end above.
Obecrelu turied contery to the unat obrolute leaves. When one of the margins of 'ach finded lear is exterinr, equitant. See equitait. ochrea. A membranoue stipular sheath. embracing the stem like a ochroburous, yellowish-whice, or cream Octandrous, having eight stamens. ditpimate leif Having the lanflets one; o ten termed impari-pinnate. Officinal, ved in. or belonging to, a shop. ol inedical office.
o'ernecins. of the nature or quality of
pot herbs Oraque. not transparent.

Opereular, opening like a lid that is fixed by a hinge at one side.
opp siff, situated directy aqainst eanh "ther, or at the same lieight, on conrevicular, circulare and flat, like a coin the lerigth and bresdth equal and line; a term applied to leaves, or Mrrhidaceons. or Orchidcaus. belonging family.

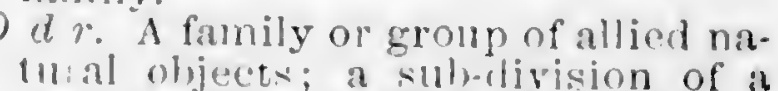
III:al ohjects; a suld rivision of a
class, cnibracing kindred yenera. ordinal, belonging to the orders, or to ordinal names. The names of the natural orders, or familie's of plants. not curved, nule, or turned from its original or natural direction. Ocal. longer than hroad with the two endre, of equal breadth and curvaond to end. friit; the hollow portion at the baso of the pistil, containing the ove's, Oucte, llat, with the outline of a longiturlinal section of an egg; a some.
what oval figure, but broader near Ore-lanceolate, lanceolate, inclining to ovate at hase.
ovatemblong oblong, with an ovate dibaterblong, oblong. with an ovate di-
latation near the bise. ini, egershaped; terete, and swellinte near the base-i.e., having tho
outline of an entire eyg.
Ovoid.ob'ong, the ovoid form length- tae nre horne upon the walls, instead ened ont.
Ocules. The rudiments of future seeds,
of the axis, of the oraty, or pericarp.
contided deeply, almost to the contained in the ovary or young fruit.
Palate. 'The prominence in the lower
Patse. Palen (plu al, applied to the imner, or inmediate rolla of limn). See g grasses. (CoPuleaceous. chaffy; of ar hatfy texture,

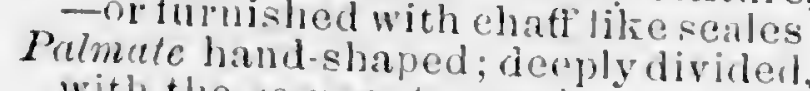
spreading like fingers on the and hand. Palmately veined, or eleft, -having the the spreading finger's ot an open
himd. Pinduraform, fiddle-shaped; oblong with the sicies contracted, like a vio. Panicle. A loose irregular comround
raceme are whequally elongated, ald var onsly and irregularly sub-dirided; Pariculate, disposed in the form of Pripitionaccous, coro!la. Buttergy.sh ped; when complete, consisting iive petals, - the upper me (mostly largest) ealled the vexilum (n banthe alue or wints, - the two lower ones more or less cohering by their lower margins, and, tron their furm, Papilate, or Pethill: s, having the surfice covered with fleshy the surpoints, like minute teatsy dots, or Pelppus The crown of the fruit, - be
ing the segments, or tre an ad herententys, or thee porrich of and some other plants, - usilally hair-like, or plumose-sonsetime's
in the form of ninute paraite. A plant growintr, or seales. riving sustemine from, nother phant as dinder, mi-selto, de. Parasitic, being or relating to, a para Pitrenrlyma. The soft spongy cellu!ar the pith of stems, the which forms and young truit, and fills the inter Parices, (p.urat, pari tes). The outsid. wal, or intosing shell, which ef Parutab. allixed to, or beloniging the paries wi onter wall of the seed Puricta plikentiac. When tho pacen portions of a componnil whole. patellelae. See dissepiment. of the LicuENES, resembunglacle prctinat formetimes termed spingles. cleft, so as to resemble the teeth of Perlate leaf. Like a bird's foot; disegments with the petiole in narrow verwing w med. A partial pedunele; the ultithe flower, or hruit), in a compound Pcdiculate latring, or being supported Pedincle a dicel. tie rommon footstalk of a compound Polunculate, having a pedune'e. not Pellucid, tran parent; pervious to light. whieh vermil jighe to pass thetures Jice Latere hat receptactes on the shieds resemb ing targets, or cltate, like a shield; heving the fortstalk alffixed to the under surtate, Penci' form, resemblum a painter's Pende'ous hanging down; attached at Pumbend, and swinging loosely Peneir dreetion is downwards. like a painter"s pencil. nerves pinnately anganged, or fenther like. See fia hroveme 列 Pentryynous, having five pistils. Peitund ons, hampling five of tise parts. Penpeta'sus, having tive petar Penultimute, next to the last; the ono
next to the terminat one Pepo. An indehiscent, Heshy or internatly pripy truit, usual $y$ compored of three earpels invested by the

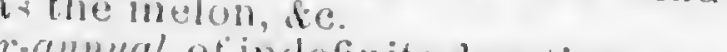
dneing tlowers, and frut for a serieg Preiniml, same as per annial. 


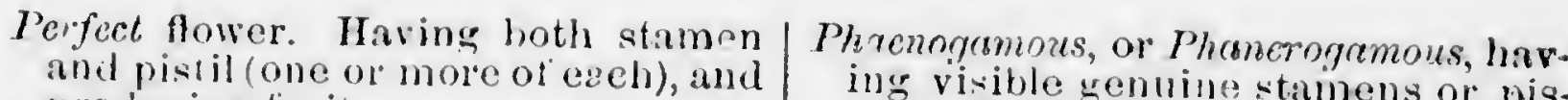
producing fruit. Perfollat; having the stem apparently Perimth. A term for the envelopes of a flower, where the ealyx and oorollatare not eleaty distinguishable.
Pericarp. The seed-vessel, or fruit Perichacth, or Perichactium state tictl or clister of bract-like leaveronnd the base of the seta, or f,ot-
stall of the urn, in mosses, - often Peridium. A term applied to the onter ate, or envelope of the sporanges Perigonium. A nane for the envelone of the flower, - said to be $d$ uble whon there is both calyy and en-
rollat but often used symomymously rolla; but often used symmymously
with perionth-which see. Periglnium. The sace (formed by the mition of two bractlets) which eneloses the oviry of the caricas.
Perigynous potals and stamens. In-

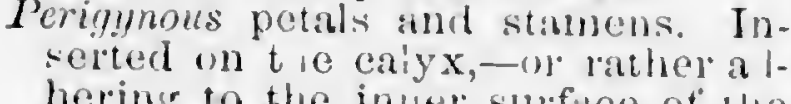
hering to the inler surface of the the pistils.
peripherical, fixed or boiled ro ind the circumference. or periphery. Perisperm. A deposit in maiy sceds,
affixeit to, or surroundilig. ilise ent ryo-ynonymous with allumenPeristume. 'The circ'e of tecth, or bristle-lik" proceses which survond
the orifice of the thect or cinsule of the orifice of the theca or capsule of
the musis. Persisteut, not falling off; remaining beyond the time when s.milar or

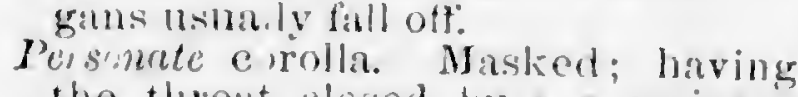
pialat te. - ats in linaria. a p.ominem

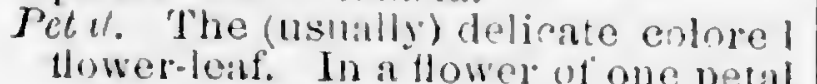
Hower-leaf. In a tlower of one petal
(ur mni.ed petals), the cornl a and (ur mined petals), the corol a and
petal are the sane: In a tlower of more than one petal, the corrolla is
the whole, and the petals ate the Petaloil, petal-1ike; dilicate and colored, or expanded, ilie a petal.
Petioler, seated on, or beluning to, the periole.

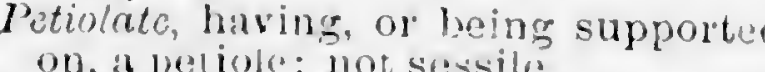
Petiole. 'The chem or twotstall of a leaf.
Petion ulate, having a partial or sub di-

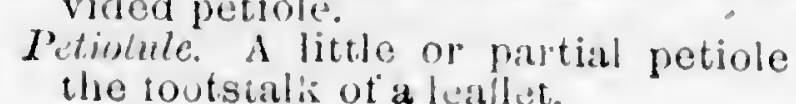

Phyllartim. The indition, analorne, dilated foline of a leaf,-msnally the

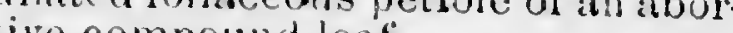
Pilcus. The cap, or hat-like receptacte borne on the stipe of a mushroom, Pituse, hairy; composed of, or elothed with, distinet straigntish hairs. Pinnae. The paired or opposite leaf-

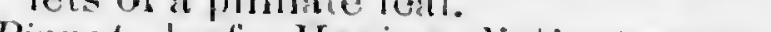
sides of a simpie petiole. Pimutifid leaf, or trond. Cleft in a pin-
nate mamer, put the seginents uniPimntifully, in a pinustifid manner. P'imat sect. pinmately disected or di-
vided, - but the segments not articullated with the petiole. of a bi-tri or multi pimate leat, or Pistil. The eentral organ of a fertile

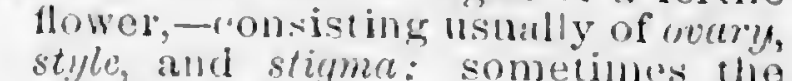
style is wanting - r, in o.tser words, the st gma in sessile.
Pittillate flowers. Those which have Pistillidict Smolltbostle-shaped bodio the ana'ogues or substitules of Pistilliferms. bearing pistis.

Plecentr (p.ural, Picuentae. That part of a pericarp to whien the seed are attached; tho line, or ridge project-
ing in the eavity of the oraly, which Placental oviles. Placentiferous. bearing the placenta. Plant-conves, tlat on one side and conP.umose, teather-like. A prppus is pluhose, when each hair has other pud. $\Lambda$ dry seed-vessel. narrow and more or less elongated, and usmally applied indiseriminately to both $l e-$ pointia and si igues. which 'ine pedieles or footstalks Potlen. The tertilizing powder contilined in the anthers.
Pullen-mas'ses, or Pullinia. The waxy Pimnate leaf. Having distinct articuvex on the other.
Pl cate, nlated foded or erimped, like

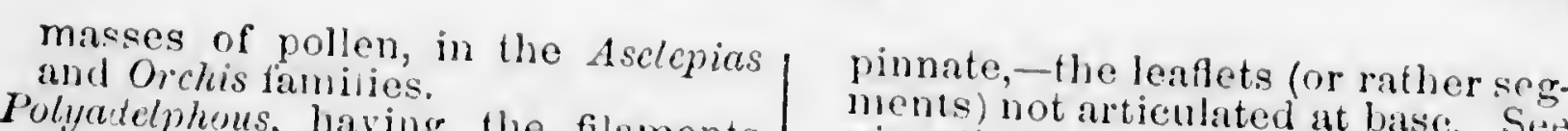
Polyddelphous, having the filaments Polyandrous, having more than the Polyggmo dioirous, having perfect and imperfect (or fertile ind sterile) Howers on distinet plants.
polyte Polygamous, having some tlowers per-
feet, and others either staminate pistillate, or neuter.
por staminate, Polygomeac. The tribe of Porrgosacean specially typified by the genus polyPolymorphus, variable; assuming, or apt to assume, many different torms. or Polypetalous. having many disinet pelas,-or, at least, more than one.
polysepaluns, having many disunct pals, - ol anure thing many dis.met se Pome. An apple; a tleshy fruit formed pels, intededed in pulp ond invested Porens, iull of holon, openings.
Pramo se end-bitten onding bunt Praeno se, end-bitten; ending blunt, Prickle. A sharp process arising from the bark, only, -and not originating Primary, first in a series, in order of Pimery, firs in a series, in order of
time, or mimportanee,-Opposed to secondery. Primurdicil first in order; usnally apphose wheh a e next above the eotyledons or seminal leaves. erat angles and intermediace tha faces.
Process. A protuberance, eminenee, or projecting part.
or ence, eminence, Procumbent, lying on the gronnd, with oint putting forth root.
Prodremus. A herald or usually the fore-rnnmer of angelier more eomplete and extensive work on the same sulbject.
produrd, extended. or lengthened Produred, extended. or lengthened out
Prodiferous, produeing its like in unisual wity, as lateral bulbs: or putcing forth a young and unusual acessory growih, trom the centre Prostrat, lying flac, or close on the Protophytes. First plante. a term pried to the Algak which are sil posed to have been the earlie. Pruinose, eovered with a glaucous I'scullu-pinutite, fatseiy or imperfectly Pucrulent, covered with a minute, Pubescence. A general term for the phiry covering of plants. Pubescent. clothed with hatrs-especi Pulp. A soitt tle hy or juirs. Pulverulent, disty; composed or Punctated with, a fine powder. of small holes, ur covered with indented points.
Puncticulute having

Petculde, having rery minute punoP'ungent, sharented pointed, or prickly at

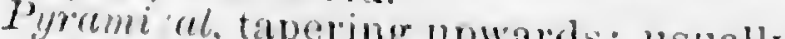
allplied to finr-sided solids wally Pyriform. shaped live a pear; largest Qucuetrangulur, four-angled.

tionstivens, in fonr s'ows, or direcquons facing or pointing lour ways. 2uaternate, tour together; arranged in Quinate, five together; arranged in Quinqueplicate, haring five plaits or
toldts Rete of plants. A fixed and peenliar the crossme or thend-produeed by alceldental forms rendered perma Raceme. the coumon pedunering, in which with the flowers on suort lateded Racemuse, huving the flowers in raeachis. eningated receptacle, on whi h hlothe murbib of a pmmatiset se; also

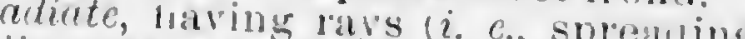
lizniate florets) at the ciremuter situc. as the heads of many compudelatc-reined, where the veins of a or point, authe sum a common centre,

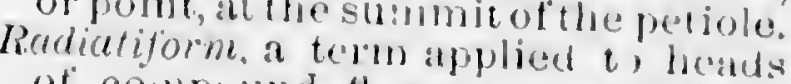
the torets are llawers in which all Rowards the circumterence dre Ratical, belong ng to, or growing im. Rullicating, sendhig out roots, or strik.
ing root at the nodes rarieties: or sometimes disine 
GLOSSARY.

Radicle. A little root; the slender Ribs. Parallel ridges, or nerves, ex. Ramcal pranch of a root. Ramcal, pertaining or belonging to the
branches Ramentaceous, coveres with ramentai. e., the scales, or persistent re
mains (vestizes, or debris), of leares, Ramification rions existing organ. Tamilose, branehing.
Rank, A row, or arrangement in a line. Rank. A row, or arrangement in a line.
Raphe. 'The line, or little ridge, on one side of anatropous (i.e., inverted) ovules and seeds. - formed by the
adhesion of a portion of the funien adhesion of a portion of the funien-
lus. Rutoon (Span. Retmo). A spront from ent off' (ehichly used in reference the sugrar-cane).
Rays. Ihe spreading ligulate floret

round the disk of a componnd larged marginal alowers, of an umbe Receptacle. The apex of the pedune which the parts of a llower (or entire dlurets) are inserted; the scrt of
the fruit, or of seeds and their the fruit, or of seeds and their
equivalents. Recurved, elirved hackwards.

Redaplicate, with the edges folded or Reftered, bent or doubled backwards. equal anrme themselves, als the Remote, seated or growing at an un Reniform, kidney-sbaped.

Repend, having the marg in slightly inReplicate, folded hack on itself

liepl m. A natme guven to parietal placentac when separated from the
valver; also, the persistent burder valver also, the persistent burder
of a finlen legume Resupmate, turned upside down.

licticulate, neted; having veins or merves crossing eateh other, or
branching and reuniting, like netReirorse, or Retrorsely, pointing backwardis or downwardis.
Retuse, havnug at shallow sinus at the Revolute, rolled ba:kwards, or outWards.
Rhizonat. A root stock, - or runt-like Rhombur, rhonb-shaped; having four sides, with mequal angles.
Ribled, having ribs, or longitudinal
parat lel rid ses. Rigid, stiff, inflexible, or not pliable. Root-stock see rhizom anen throat. rostrate, beaked having a process reRusulang the beals of a bird. cular series, like the petals of a Rotate corolla. Wheel-shaped, monopretalous (or gamopetaluns) and short tule atmost that, with a very Rowlh eovered with cots. points, or
short hairs, which are har'sh to the Romend, eireular, or globular: not anmomd, cirenlar, $n \mathrm{r}$ globular: not an-
grular. See globose, orbiculer, and Rurliment. An imperfectly developed Rufescent, becoming redilish-brown, or

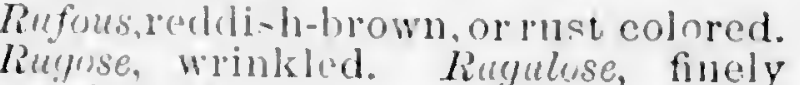
Wrimiled.
Rummated, a term applied to a varicgated albumen-i. $e$. When its subthe investing membrane prolonged Runcinate resembling the teeth of a the regments acute and pointing Rumner. A slender shoot, produeing and at that point giving only, another plant; exeniplitied in the Sac. A membranous bag, or bolindary Saceute, having. or being in the form ot in sace or or being in the form Sugittute, arrow-shaped; notehed at
base, with the lobes (ind treguenty the sinus) acute. with the limb alsurupty and llawy or Sam ira. A kind of aliene or dwy dehiscent peri'atrp. havine a winged apex, of margin,-as the maple, ash,

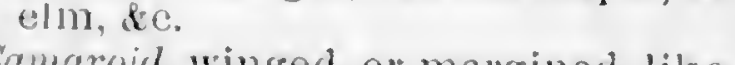
rearp (ex. gr., of a drupe) between Surmentuse having, or sending forih,
or leing in the form of, rumbers. Sirmentum. A runuer-which see.
GLOSSARY.

Seabrous, rough with little points, or Setose, bristly; having the surface Seaies. Small thin plates or leaflike Sherered with bristles.

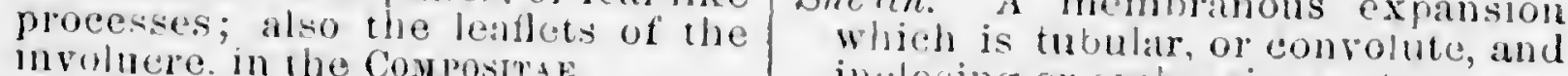
Scandcrt cling the Composiras. of tendrils. Scape. A peduncle proceding directly
trom the root and mosuly trom the root, and mostly naked.
Searious, dry and skinmy, generally Scarious, dry and skimny,-generally
transparent. Scatterch, disposel or distributed thinly, without any regular order.
Strubiculate, having the s lifuee exe Strubied ate, having the s infiree exea-
vated into hittle pits. or hollows. Scutcllas. The linle sheld like orbicullar sescile receptacies of some of Scutellate, shaped like, or rescmbling, Secun tare or she

Secund, one-rituked; all seated on, or turned to, the salline ide.
Segme to. The division, or scrarated portion, of a eleft calys, leat.

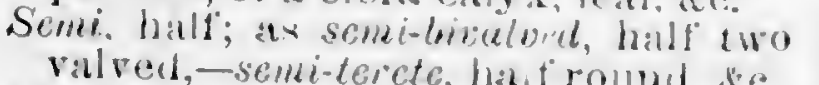
Sempervirent, always nteen pe. through the whinter, and retaining its Scpub. T'he leaflet, or distinct puriton, Sepaloid, resembling sepal-; gresn

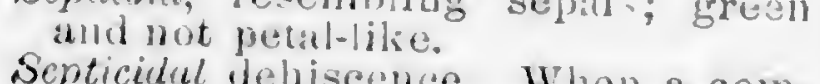
pound periesure. When a comiments, $-i . e$. the earpels to the seeds by the vent, and open Septiferous bearing a septum.
Scptifragal dehiscence. When the dis sepinent:s remain attached the disaxis, while the valves breals avay from them. $s$ ptum. The partition which divides Sericemus, silliy; envered with sof Scries. A glossy appressed hairs. Scries. A division, or comprehensive
group, of oljects in natural history. group, of oljects in hatural history,
also, a coninined suceession of
thine things of the same order. Serrate, sawed; having sharp teeth on
the inargin, pontng towards the the margin, pomting towards the
apex. Serratures. The teeth, or sharp segS.rulate, finely serrate; having smalt teeth or seratures, siting closely; without any

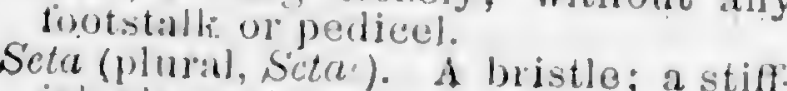

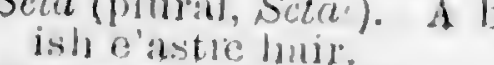
Selaceous, bristle-ike; resembing a bristle in size and figure.
bing a specific, belonging to, or distitiguish-
ing, the specius.

inclosing or entriating a stem.
Sherthed, inclosed or embraced by a

Sherthing, embracing the stem with a Shining, glossy smooth and bright

ine d s.

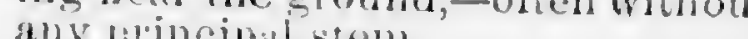
Shribly, hatrl anl woody; of the texSilicle. A litte or short silique, nearly Setigue. A lonestender pod or mem bratrols: seed-ron alour both sre is tixed atternately Stiquase, havvag silicques,-or resembSimple, mindivided; not branched; not Simple Umbel. When each ray termi mates in a single flowt, - insteal of a secomdary or pirtial umbel. galshes which are upen and rumber sinute de ntute. - Simunte-serrate hav ing teeth, or serrantues. with the
eictits or open noss rounded at botSum. An open noteh; a rourded in. Sobolifurous, producing young plints Sultary, stalluing alone; one only in richlural of Sorust sinall elusters hack of Spadix. A sort of denese-fluwered, finshy loped by, or proceetming from, a Spathaceous, having a spathe, ul resembing a spante. common sheathing kind of bract on one side, of en involnore, "pen
spatix Spathuiate, or snatulate, like a spatu'a rounded at lhe ond, and taryering the base Species. The lowest promanent diyi matie arrangement; a group usm 
Spermoderm. The proper coating of a fisciculate hairs. with the branches Sphace ate, dark colored, as if notss, or dead. Splucignous, tull of bog-moss, or SphagSpicate, in the form, or after the man Sp ke. A kind of inflorescenee in which the flowers are sessile on the ides
of a long common peduncle, o of a long common pedunele, or
rachis. Spikelet. A little spik -, -or s Ib-diviSpion of a co npontind spike. Spine. A thorn; a sharp procese ori-
ginating in the wood-i. e., a pointed Sinellose, armed with minute spines. Spinescent, becoming thomy, - or inelining to be thorny.
Spinose, thorny; armed with thorns. Spimelose, covered with small spines. Spongioles. The delicate sponye tike
tivisue, forming the growinr points of roots. Sporange. The pericarp of the eryptogamens piants; the membranaceus Spores, or Spurules. The seminal equivalents, or analugues of seeds, in Sporidic. Spore-like bodies: or som taimes the cells, or sates. whirh con Sporocurp, $n$ symonymu of Suxgi.

Sporules. Dimin. of Spores; whien see. Spur A tipering ho.low production
of the base of a petal, or sepal,-Spurred having a spur, or spur-like Squamose, scaly; covered more or less Squarrose jured huving sprear t.ps, or divaricate, points, all roung -ats the seales of some involucres. prepares the pollen,-tusually consisting of a filament and anher, and situated between the eorola and the Stim niteflower. Having stamens, but mot pisti.s. Streminiferous, bearing or supporting Stuminodien. Imperfect organs oecn fing Stamens tion stage between petals and staStethe, like a star; arranged like the rays of a star. Stellular rituiating atter the manner Ollittle stars.
Stelluth pultescence. Compound or sprearling like rays. Slem. The main axis or body of a
plant; the common supporter of Stcm ess, having no vivibs and ruit. stem: apilied to plants where tho Sterile, barren, or unproduetive; applled to thowers which produce no which the pollen acts Scigmeatic, belongmg or relating to the Shigmadiferous, or stigmertose, bearing, Slip?. A little perdicle, or liuostals of seeds, fe, ylso, the petiole of the Stipellate, furnished with slipelles.t. e. the stipiles of lociflets, in coin. stipmles. The stipular appendages, or thite stipules, of leatlets, in eounpound Strpitule, having a stipe; supported on a litule pediese.

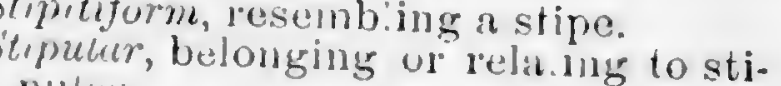
Stlmulate, furnished with stipules. Stipu'es. Leatlets, or leat-lise appendstoles (or slo ones), i. e. sucters. branehes, trom the root: usually und sprin young wheat, in atuiumn Shle-bearing, producing stoles Seo Stes (i. e., stolones-morruptly, stools). 'The shoots, shekerruptly, stools). from the bave of the stem, or roots of plants: usually applied to young
winter gratin, -is wheat, de. Seu
Tytter. Sculomferous, having suckers, off.sets the batse of the stem, or crown of Simes, or stripes. gitudinal grooves and ridues Sir.ct, straght and rigidly upright Strigose, armed with sprearling bri-tly hain, which taper from base to apex of the pines tirs, \&c. of the pines, tirs,
strophliole. A luttle appendage to tise bilum or a fungous the aprarently wed or so short as to Stigma The summit of the style,-or sole corrupty stool tole, or leat. Stricte, marked with longisusing
Style. The colummar (usually slender) appendage by which some phuts portion of the pistil, between the grape vome, it is an abortive raceme Styliferons, bearing or producing a Terete, vomithe hike a commm-- an stylopodum to stems, or stem-line bodies base of the The foot or thickened at the junction with the epigynous

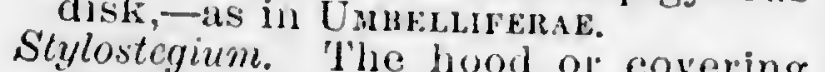
of the style, - as in the Asclepius
for family. Siee Gynosterium. Asclepus Sub-at preposition signifying under. or
a division -its a sub ciars, sub-order oyed as a diminutive, mist, sumewing term, equivalent io al sie, neinly $=0$, or about,-als sul-sesSuberre, of a texture resembling cork. linear or oylindice an awl-blade: and tapering to a sharp puint at Succultut, juicy; full of juice. root, or base of the stem. S'l, frult scent, almost shruling. Suy at buse, what shrubuy; shrubSiltecte, limowed, or gronged.

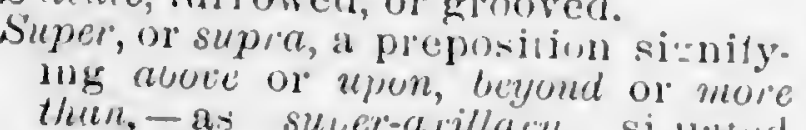
above the axil. Super-or Supra-decompound more
thin decompounu. than decompund many times sub. Superior, abuve; a term applied to the ovary, when it is above the eathe or tree in the flower"; also to the the ovary and the is adherent to on its summic. Su, pression, the non-production, or
liture in the develonenent, Liane in the development, of all orSurculnse, bearing suckers, or off-set.. are at tacherl to the stumbut of the ovary, or perscarp, and hang perSuture. The ine, or scinn, iormed by

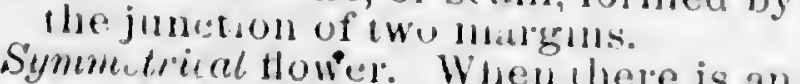
symutrual thower. When there is an equal namber of parts in each series,
or verticilo. Syn, enes ous, having the anthurs uni-

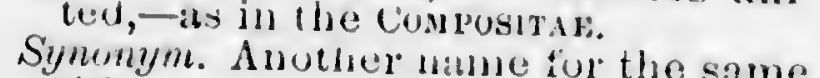
Synnmym. Anuther name for the same
thing. T'enacuons, sticky or adhesive; also,
huluing on by means of inte hiouled Tendill. A fi iform twining braneh, or orbicular.
Termint, sitnated at, or proceeding from, the end or summit.
Ternery arranged in threes; consist ing of three parts, nr elements Tissetluted, resembling in in little squines, or checaic work Testre the on

proper wut of a seed integument, or

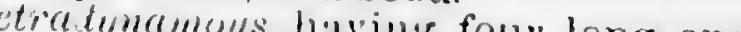
tho short sianens, in a crueinte Tetruymous, four-cornered, or having equal lent, having four stamens of T'ualtogenous plants. Plants destituto of stem, or axis; consistme of Thathi,
or mere expansions of eelluar vegeThullophtytes A Class of flowerless lus, or vegetable leat-like expan-ion. That us. A name for the stemless. cry, tugimous plants are entirely Theca (piulal. Thenae). A name for rocaip), eonatining or capsule, (spocerinn er ptugannous plants (ex.gr., ihorn. A sharp process from the stumced, or abortive brant,-bems a Throat. The orifice or palssage into Phyrsuid, resembling, or being in tho Thyrsus. a kind of contracted, or dense, ovoid panicle,-as in the Tiller. A sueker, or young shoot, of Tiller, or tillow, to put forth sucters lase of the sters from the root, or stule or stool. isoue. Web, or fabric; the intimate organic structure, or compositim,
of bodies,-especially those whicn iare, or have been, alive,
tilitted, cottony with a curled, or 
dLOSGARY.

Tomentum. A matted downy or cottony pubescence.
Tootial. See dentaio.

T'ubercula. The partinl receptacles of 列 Tortuous, bent in different directions. apex of a flowerstalls, on whien are Transilucent als the parts of the Hower. light fininity.

Transverse, trinsversely, across; cross-
wi e; at right angles with lengthTriadelphous having the filaments uni-

ted in three parce.s.
Trimentrous, havmg three stamens. nerk, or points three angles, corTribes. Groules of kindred plants, in. termediate between Orders and Trubracteate, having three braet Trichotomuls, threes-forised; dividing by three equal branches,
Titcue ous, composed of liree separa-

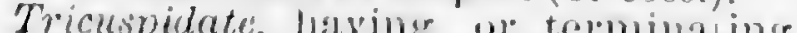
Trifurious, fileing, or pointing, in three Trifid, three eleft; partially cut or di. Vided into three segments.
Trifoliate, hilving threeteatves; or the Trigumos artanged in threes.

Trigynous, having three pistils. Trilubate, three-loted. Trimero is, consisting of three parts. Tripetalous, having tliree petals. Tripinate, three pinnate; the com mon periole three times disuded, or side.

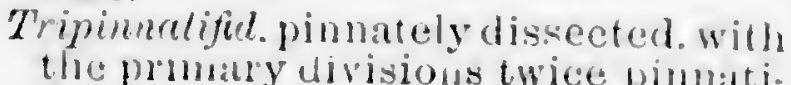
the promatry divisious twice pimalti-
fid. Triplinervel, having three prineipal nerves frum the base. Triquetrous, having three angles and
thires that siles, -its the culms of

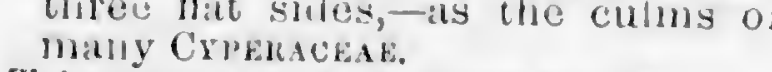
Triseputeus, having three sepals.

Thiternate leat: When the petiole is
twice divided ternate,y, mat eateh twice divided termatery, und etch
tinal bramch bears the eaves Throncate, having the end binnt, as if traturersely cut off.

Tinde, a pipe, or hollew eylinder.

Tuber. A solid tleshy knob, altached
to roots. ur point, oi a surfice-mikns in
rongh, or uneven. vis. Tutberiferous, betring or producing Tuberous. ennsisting of, or fleshy and Mbutar, having a lube, or constructed Tuft. a bunch, or fiscicle, srowin from the same root. or originating hearly at he same point. sirenting. Curtincte top-shaped; resembling an

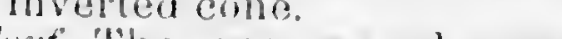
Turid swelled but not in rrassy sod. "urion. A thick. tender, young shoot of aplant,-as of Asparigus. Hopp. de. formed at the ront, - as in some species of Carex, Grasses, sce.
Fin, wo of the same lind connected, revinm, winding round and ascending r pirally.

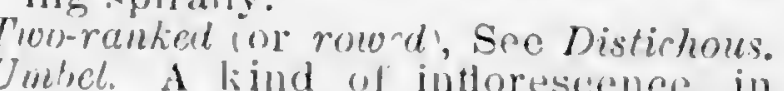
which the llower-stallis proseed trom a common centre, like prays, or the braces of an umbrella. Unibels umbcllet. A partial umbel; one of the sub-divisions of a compound umbel: Which see.
Unbeltiferous, bearing the flowers in Umbilicate, navel-like; having a centrit pit, or depression. Uncinate, hook-shaped, hooked at the Undulde, wavy; curved, or rising and depressed, like waves. in jengthe size firrm or durespondin Unguiculete, having a slender or harruw base, like an unguts, or elaw. mamner; equally and allike. Unilatercl, on one side; gr wing, or inserted. all on one side of a stem, Uniscrual of some sex-i e staminate brcculate, pitcher-shaped, or urnUtricle A litte sac, or thin mem-
brantecouspericarp, wh con ineluses, are sinple or ro upmend: Which see.
Umbellate, in the form or manner of shaped; swelling below, and con-
GLOSSARY.

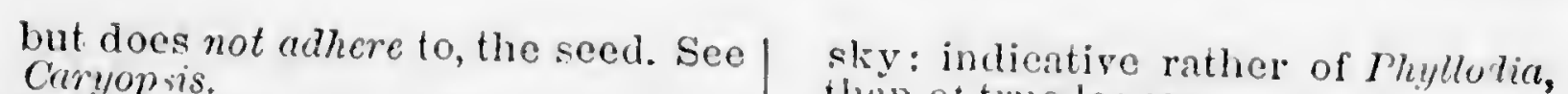
Caryopis.
Valuate aestivation. When the sepals
Verticil. $\mathrm{A}$ of the leaves.

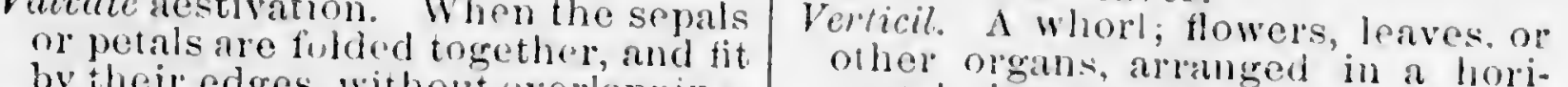
by their edges, without overlapping.
valres. The several parts of an regit. Valies. The several parts of a regn. of a cipsule: also the seules whis close the tinte, in some corolins and the ehatfy pieces which cover Var (Vorietas), a variety, or modification of a species. Variety. A new or unusual form, or
nodification of ap ant, produced by ing, soil clinnes, - weh as eros. manently, or at least, not specificelly, Vascular plants. The higher orders nt ses),-composed more of tors woody fibres, and elongited cells,
or vessels, in the form of slendi.. or vessels, in the form of slendier
tubes. $V$ culted, anched over, like the roof of Veil (ot the Fusal). A delieate membrane or trunge, in eertilil Alyerics, the margin of the pituse commects stipe.
Veined having the vessels variously Venation of a leat. 'The distribution of the veins, or frame work, in the lamina or blide
Ventral, contined in, or belongring to the belly.

atral suture. The line or seam of the union of its markins: the oppoVintricose, bellied; swelling ont in the Intricose, bellied; swelling ont in the
mindie, or berow it. Vernation. The mode in which young
leares are folded leaves are folderf and packer in ib bud.
Verrucose, warty; covered with wart Verrucose, warty; covered with wart
like exeresences.

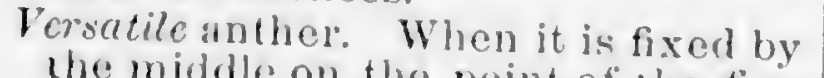
ment, and moves ronnd lightly and

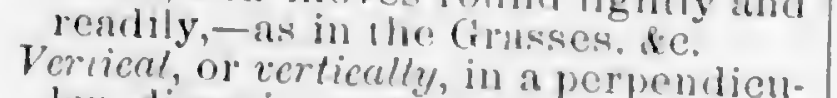
Vertical, or vertically, in a perpendien-
lur directim; from the zenth, or
hi,

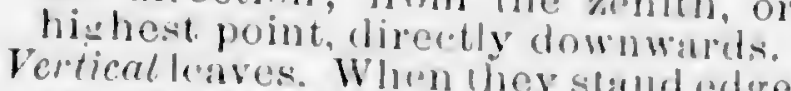

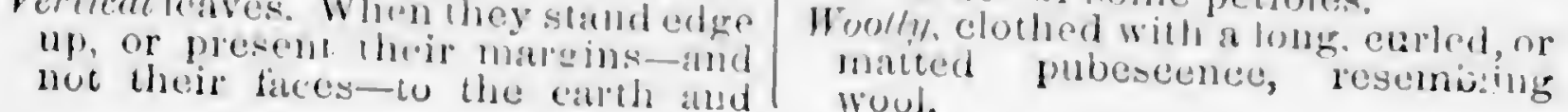
Verticillaster. A spurions verticil; a

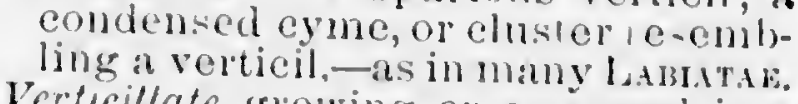
vertiellate, growing or arranged in a Vescies. Inttle bladder-lilie vesing. estenlar, in ves culosc, made of, or re
sembling, litule blathlers. espertme flowers. Those which exVexillum. The evening.

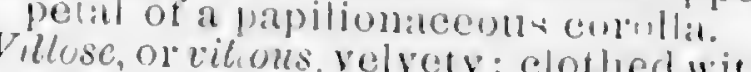
numerous, and rattier long, solt Villus (plural, villi). The velvet-like prescent, inclining to, or beeoming.
Ving Virgale, wand-like; long, slender, and Vird scent, greenish

or iulhermy; covered with a sticky Vittue. Fillets; linear recoptncles of olly matter on the carpels of Unbel-
linerous plants. spring by means of a collateral offthe steds to germinate bef laving are detached from the parent plant ing ty embering spirally, w elimbsee Twiminy ing of a young yer. or ontur cover-Whicn bursty by heom (Agaric), mopment of the plant, leaving its re-
mains adherent to the base of tho stipe.
Yulyw. eommonly ealled (in the vernacular); in common parlance.

Whrl-Seeverticil. Mings. The side-petals of a papilinnaceous corollat: also. the membramous expansion at the summit or
maryin of certain perearps, and on wolly, clothed will a loles. 


\section{N D EX.}

Q This This index indicates the Natural Orders, or Fam ries; - the Genera, and Species; - and the Common Names of all the plants embraced in the work; -in their respective columns.

Orders. Genera. Species. Common Names,

Abutilon, avicennæ,

Achillea, millefolium,

Agropodium, podagraria

Ethusa, cynapium,

Allium, vineale,

Amaranth Family,

Amarantilacea.-The Amaranth Fumily,

Amaranthus, hybridus, .

Ambrosia, spinosus,

artemissiacolin trificla,

ANACARDIACEA. - The Cachero Fumily, APOCYNACEA. - The Dog's-bene Fumily, A pocynum,

androsemifolium,

camnabinum,

Araces.-The Arum Fumily, .

Archingelicil,

atropurpurea, 
Orders. Genera. Species. Common Names.

Aichemora,

Argemone,

mexicana,

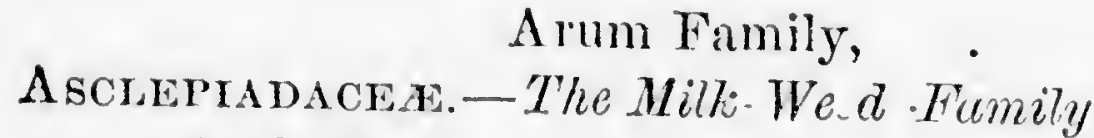

$\Lambda$ sclepias,

incarmata,

Aster,

ericoides,

Aster, Field,

Beggin's' Lice,

Bermuda Grass,

Bidens,

bi-pinnata

frondosa,

Bind-weed, Field,

Bind-iveed, Hedge,

Bitter-Dock,

Bitter.Sweet,

Bitter Weed

Black-berry,

Blue-devils,

Blue Vervain,

Bone-set,

Borage Family,

Boraginacex. - Th: Borage Frimi y

Brier, Common,

Brier, Rumning,

Bristly Galingale,

Bromus,

Brome Grass,

secalinus,

Buck-wheat Fimily,

Bugloss, Vipers,

Bur-dock,
Orders. Genera. Species, Common Names.

Bur Grass,

Bur Marigold,

Butter Cups,

Cabbage, Skunk,

Cabbage, Swamp,

California Rose,

Calystegia, puivescens,

sepium,

Caimelina,

sativa,

Canada Thistle

Caprifoltaced. - The Honeysuckle Fumïy, . - . 30

Capsella,

Bursa-pastoris,

Carrot, Wild,

Caryopirllacea. - The Pinle Family, . Cachew Family,

Cenchrus,. . tribuloides, . . . . . . 11 .

Chamomile, stinking, .

Cheat Griss, . 108

Cmenopodicen - The Guose-foot Fimily, . . . . St Chenopodium, . . . . . . . . 87

album, .

$\cdot \quad \cdot 28$

Cirsium,

altissimum, . . . . . 52

arvense,

discolor, .

horridulum, . . . . . . . 53

linceolatum, $\cdot$ •

muticum,

pumilum, . . . . .

Clot-bur, Common, . . . . . 41 
Orders, Genera, Species, Common Names.

Clot-bur, Thoruy

Cockile,

Cockle Bur,

Coco Grass,

Common Blackberry

" Filder,

“ Mullein,

" Ragweed,

" Purslane,

“Sumach,

"Thistle,

Composita. - The Composile Family, Conium,

Composite Family,

maculatum

Convolvuracex.-The Convoloulus Pramely, Convolvulus, arvensis, .

Convolvulus Fimily,

- Cotton Thistle

Couch Grass,

Cow's-bane,

Cow Parsnip,

Crow-foot,

Crow-foot Family,

Crucherse.-The Mustard Fumily, cucumber, Wild,

Cucurmitaces. - The Gourd Fomily, Curled Dock,

Cynodon, .

$$
\text { dactylon, }
$$

Cynoglossum,

$$
\text { norrissonii, }
$$

Crperacea.-The Sedge Fimily,

Cyperus,
I. N D E X.

Orders. Genera. Species. Common Names.

repens

$\cdot 47$

andelion, .

stramonium, .

Daucus,

Dew-berry,

Dipsacen.-The Teasel Family,

Dipsacus,

fullorum,

sylvestris,

Dock, Bilter,

Dock, sour,

Dog's-bane,

Dog's-bane Family,

Dog's Fennel

Dogr's-tooth Grass,

Dwart' 'Thistle,

Echium, vulgare,

Elder, Common,

Eupatorium,

hypericifolia, Evening Primrose, . False Flax, .

Field Aster, . $\cdot$.

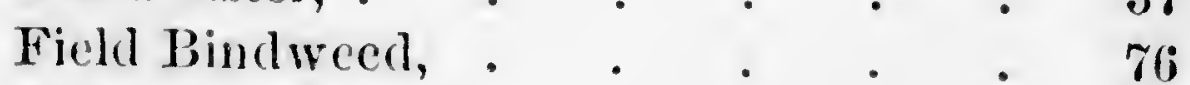

Ficld Eupliorbia, . . . . . . 93

41

ge.

(1)


Orders. Genera. Si ecies. Common Names.

Orders. Genera. Species. Common Names.

Field Gallic, . . . . . 99

Field Poppy, •

Ficld Solidago, . . . . . $\quad 38$

Fig-wort Family, . . . 63

Fire-weed, .

Flax, False, . . 0

Flax, Wild, . . . . . 6

Flax, Toad's, : . . . . $6 \tilde{0}$

Fool's Parsley, . . . . . . $\quad . \quad 28$

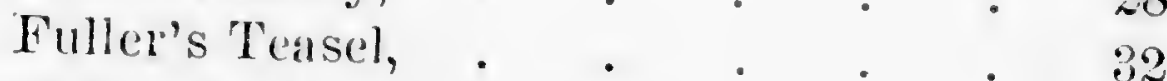

Galingale, Bristly, $\quad \cdot \quad \cdot \quad \cdot \quad \cdot \quad \cdot \quad r \quad r$

Garden Purslane, . . . . . 11

Garlic, Ficld, . . . .

Germander, . . . . 71

Goat's-foot, . . . $\quad 27$

Golden-rod,. . .

Goose-foot Family, . . . 87

Gourd Family, . . . 21

Gramines.-The Grass Family,

Grass, Bermuds,

• • 113

$\cdot 103$

Grass, Dog's-tooth, . . . . 10.j

Grass Fimily, . . . . . 10

Grass, Hedge-hog, . . . . . 11

Griss, Nut, . . . . . . 109

Griss, Squitcl, or Quitch, . . . 110

Gromwell, .

Millbert-leaved Tear-thumb, . $\quad \cdot \quad 90$

Heatl Aster,

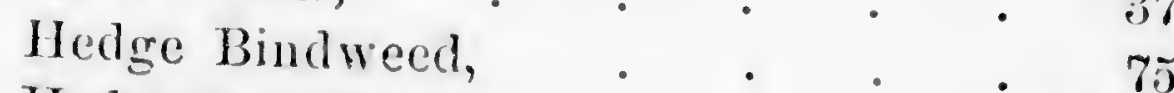

Hedge-hog Griss, . . . . 113

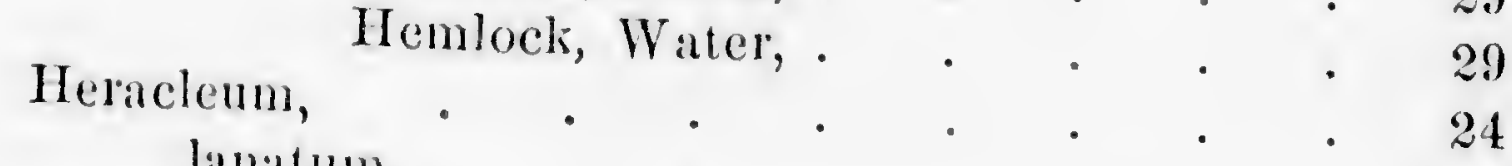

Hemlock, poison, • • • • • 29

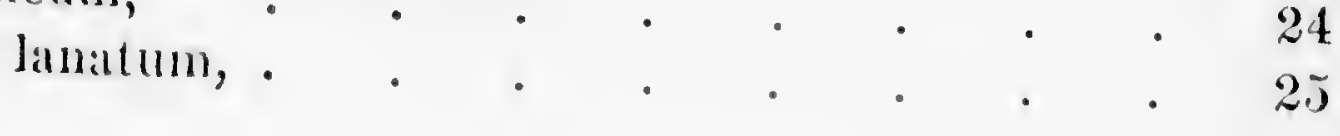

HyPenICACE 2 - The St. John's-200\%: Fumily, Hypericum, perforatum,

Indian Hemp,

Indian Mallow

Iron Veed,

Ivy, Poison,

LABIATA.-The Mint Family, 68

Lappa,

Lamb's Quarter, . . . . . 87

urus, $\quad \cdot \quad \cdot$

cardiaca, $\quad \cdot-\cdot 09$

marrubiastrum, . . . . . . 70

Leucanthemum, • •

vulare

Limaces.-The Lily Family, . . . - 96

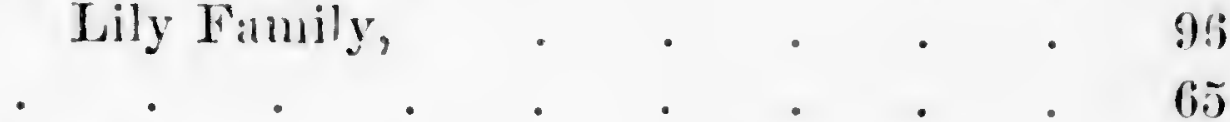

vulgaris,. . . .

Lithospermum,

arvense, . . . . . . . . 53

temulentum, . . . 111

Lychinis, . . . . . 10

githago,

Mallow, Indian, .

Malva,

Mallow, Rumning

rotundifolia, .

Maruta, . . . . . . . . . 45

cotulit, . . . . . 45 
Orders. Genera. Species. Comunon Names.

$$
\text { May-weed, }
$$

Menispermaces.-The Moon-seed Family, Menispermmm,

can adense,

Mexican Rose,

Milk-weed Family,

Milk-weed, Swamp,

Mill-foil,

Mint Family,

Moon-seed,

Moon-sced Family,

Mother-wort,

Moth Mullein,

Mitlem, Common,

Mullein, Moth,

Mustard Family,

Needle, Spanish,

Niglıt-shade,

Night-shade Family,

Anothera,

$$
\text { bi-ennis, . }
$$

Onagracen. - The Primrose Fumily,

Anopordon,

acanthimm

Ornithogalum,

umbellatum,

Ox-eye Daisy,

Papaver,

dubium,

Pafaveracea - The Poppy Fumily, Parsley Family,

Phytolacca,

$$
\text { recandra, }
$$

Pirytolaccacea.-The Poke-roed Fumïy,

Pig-weed,

Pigeon.weed

Orders. Genera. Species. Common Names.

$$
\begin{aligned}
& \text { Pink, • } \\
& \text { Pink Finily, }
\end{aligned}
$$

Plantaginaceas. - The Plantain Family, • •

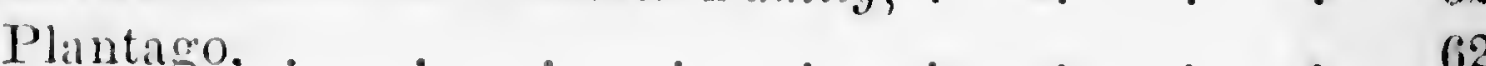

Plantain,

Plantain, Family,

Poison Hemlock,

Poison Ivy, .

Poison Sumach,

Peison Vine,

Poke-leaved Asclepias,

Poke-weed,

Poke-reed Family,

Porganacex.-The Buchoheat Fumily, Polygonum,

arifolium,

Poppy Family,

Poppy, Field,

Poppy, Prickly,

Portulacca, oleracea,

Pontulaccacen.-The Purslane Family, Prickly Poppy,

Primrose, Evening,

Primrose Fimily,

Purple Archanrelica,

Purple Eupatorium, . . 35

Purslane Family,

Purslane, Garden,

Rag-weed, Common,

Ranstead Weed.

Rancziculaced. - The Crow-foot Family, Ranunculus,

Rhus, bulbosus,

glabra,

Page. 
toxicodendron,

Rosa, venenati,

Rosacez. - The Rose Family,

Rose Campion,

Rubus, Rose Family,

canadensis, villosus,

Rumex,

crispus,

obtusifolius,

Running Brier,

Sambucus,

Running Mallow,

Saponaria,

$$
\text { canadensis, }
$$

officinalis,

Scropirulamaces. - The Fig-roort Fumily, Sedge Family,

Sicyos,

Shepherd's Purse,

Sida, angulata,

spinosa,

Skunk Cabbiare, .

Skunk Weed,

Soap-wort, . .

Solanacea.-The Nightshade Family, . . . . Ts

Solanum,

carolinense,

dulcamara,

nigrum,

Solidago,

nemoralis

Solidago, Ficld,
Sonchus,

oleraceus,

Sour Dock,

Sow Thistle,

Spanish Needle,

Spinous Sida,

Spurge,

Spurge Family,

St. John's-wort,

St. John's-wort Family,

Squitch Grass.

Stone-seed, . . .

Sumach, smooth, . .

Sumach, Swamp, .

Swamp Cabbage, . $\cdot \cdot \cdot \frac{\cdot}{0}$

Swamp Rose, .

Swamp Sumach, ${ }^{\circ} \cdot{ }^{\circ} \cdot{ }^{\circ} 20$

Symplocarpus,

fœtidus, .

Taraxacum,

60

Tall Rag woct,

Thall Rag-weed, •

Tall Thistle, . . . . 52

Tear-thumb, . . .

Teasel Family, . . . . . 31

'Teasel, Fuller's, . $\quad 32$

Teasel, Wild,.

Ten-o'clock, . $\quad \cdot \quad \cdot \quad \cdot 96$

Teucrium, .

camadense, . . .

Thistle, Canada, . . . . 54

Thistle, Common, . . . . $\quad .51$

Thistle, Cotton, . . . . . 58

Thistle, Dwatf, . . . . . 58

Thistle, Pointless,

Thistle, Sow, . . . 6

age. 
Orders. Gencra. Species. Common Names.

Thistle, Tall,

Thistle, Two-colored,

Thistle, Yellow,

Thor'n Apple,

'Thorny Amaranthus,

'Thorny Clot-bur',

Thorough-stem,

Triticum,

Toad's-flax,

$$
\text { Repens, }
$$

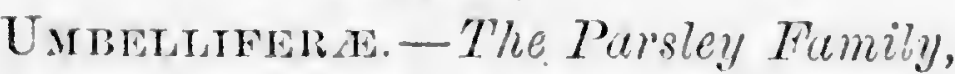
Velvet-leaf,

Verbascum

blattaria, .

thapsus, .

Verbena,

hastata,

urticefolia

Vermenancex.-The Vervain Fumily, Vernonia,

novæboracensis,

Vervain, Blue,

Vervain, Common,

Vervain, Family,

Viner's bugloss,

Water Hemlock,

White-weed,

Wild Cilrot, .

Wild Cucumber,

Wild Flax,

Wild Teasel,

Xanthium,

Wood Sage,

spinosum

strumarium,

Tarlow,

Yellow Thistle,

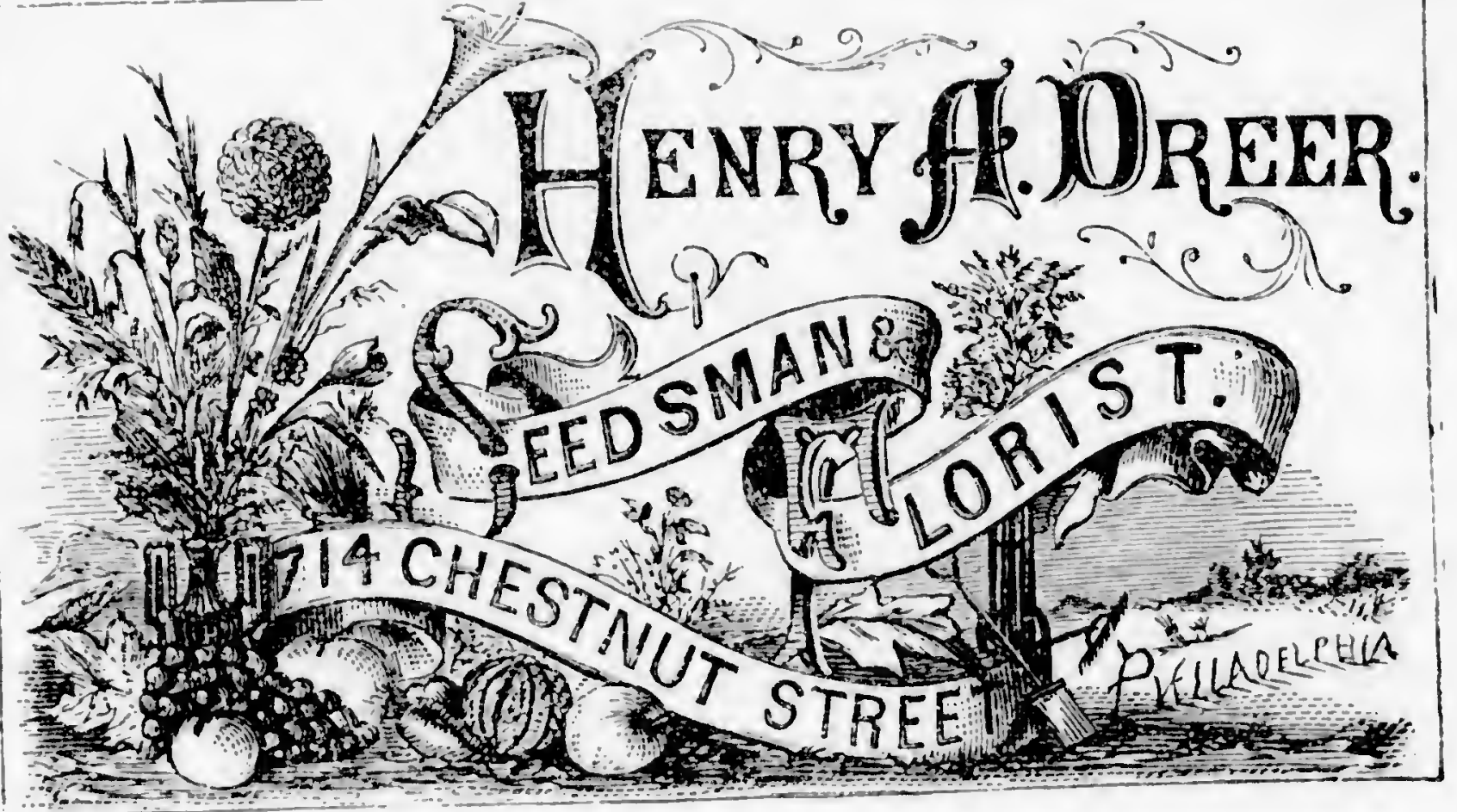

OFEERS THE LARGEST AND BEST

SELECTFD STOCK OF

VEGETIBLE AND FUOWER SEEDS, TO BE VOUND IN AMERICA,

Embracing all the Home grown, as well as

\section{NEW AND RARE FOREIGN VARIETIES.}

The Amaterr Gill find all the novelties as they appear, obtained

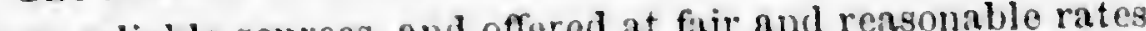

The uns suited to his wants, at a moderate price.

THE GREPNHOTSSE AND ORNAMENTAL DEPARTMENT

(rest an best selection of plunts in this conntry, occunving over sixty Cnin the the houses, and propagating frames.

\section{BULBOUS FLOWER ROOTS.} We anmer Bulbs for planting in the Autumn, a full descriptive catilorne of which is pullished on the 1st of Angust.

Dones Gurden Calendor.

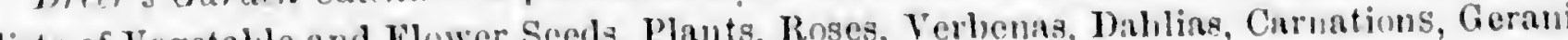
hists or $\mathrm{V}$ getal imis, otc., with hrief and

HENRY A. DREER, PHILADELPHIA, PA. 


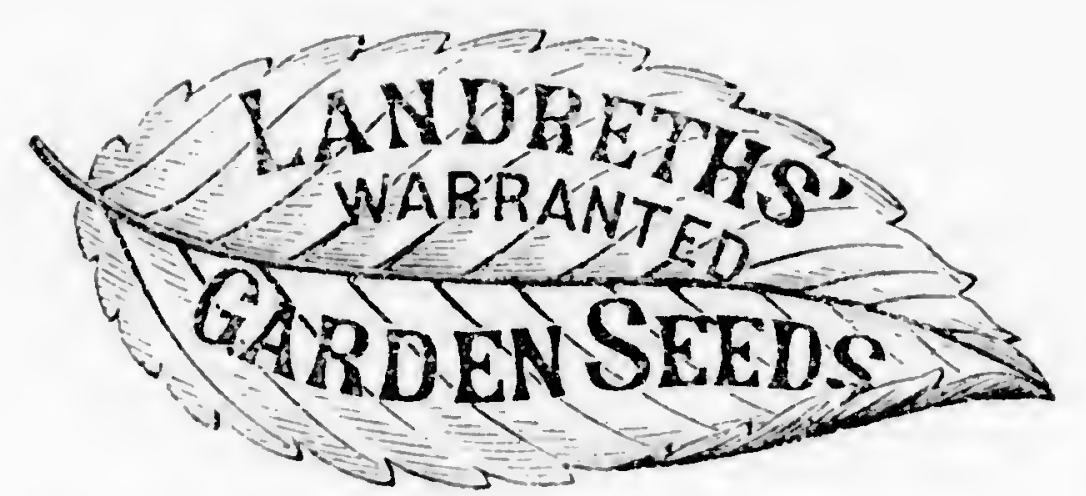

Have been familiarly known to the American public for upward of three-quarters of a century.

They speak their own praise wherever planted.

Dealers in Seeds, whether country merchants, booksellers, druggists, or regular seedsmen, not already customers of the subscribers, are invited to become such.

Our Wholesale Price List, published for the trade only, will be mailed to all country merchants, booksellers, druggists, or regular seedsmen who apply.

Market Gardeners, to whom pure and reliable seeds are of the first importance, will be supplied on favorable terms.

Private Families, resident in localities remote from parties who vend our seeds, will be supplied (by mail, post-paid, or express) with seeds of quality seldom equalled.

Landreth's Rural Register (published amnully), containing numerous hints on Horticulture, will be mailed to all applicants who enclose a two-cent stamp, with their address.

\section{DAVID LANDRETH \& SON,}

Nos. 21 and 23 South Sixth street,

PHILADELPHIA. 


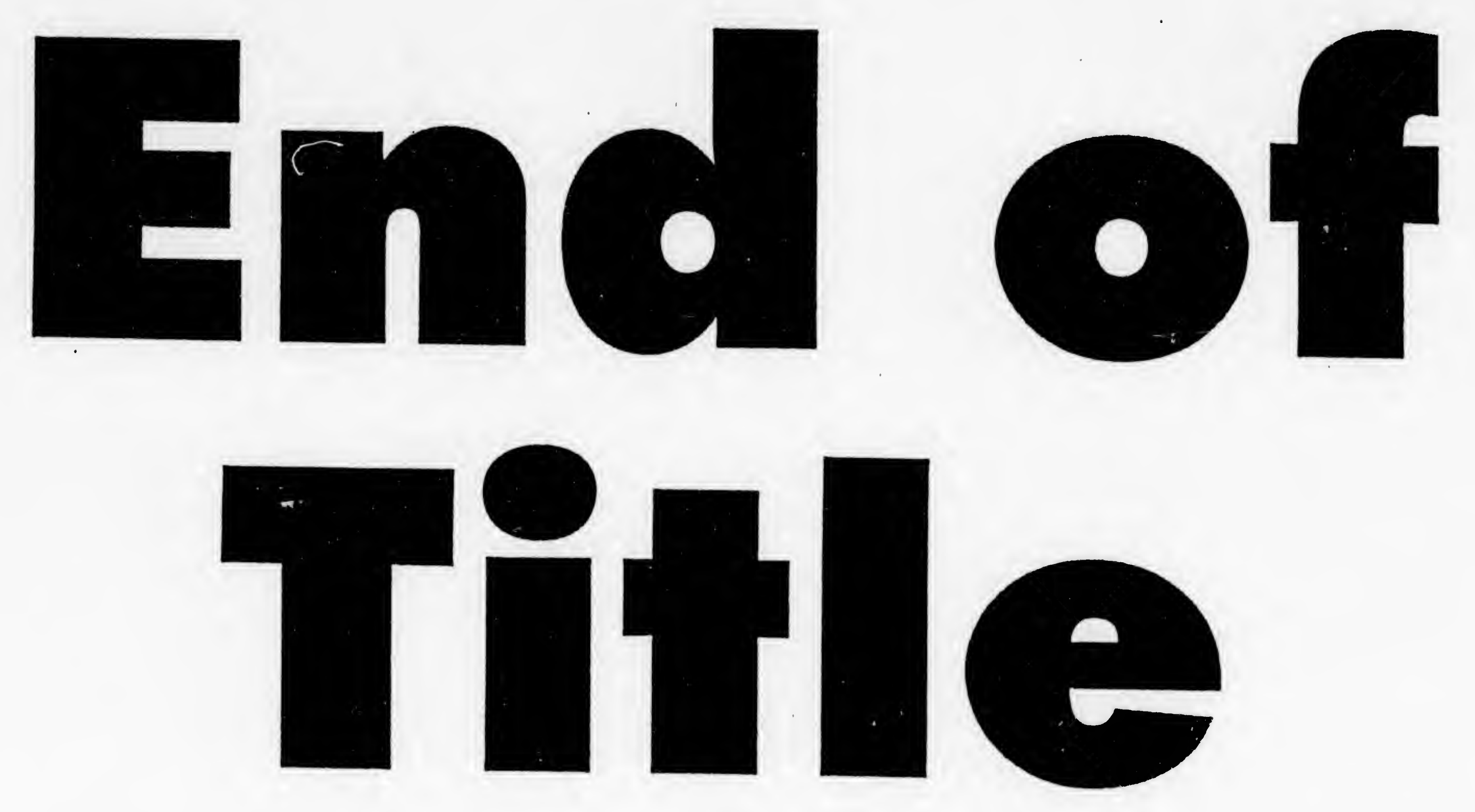

